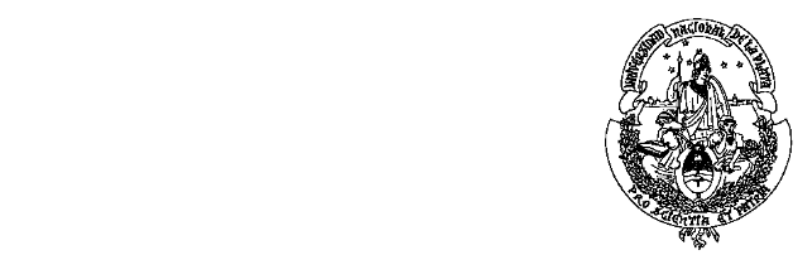

Universidad Nacional de La Plata - Facultad de Arquitectura y Urbanismo Maestría "Paisaje, Medioambiente y Ciudad"

Red Pehuén

-Tesis de Maestría-

TRANSFORMACION DEL PAISAJE URBANO EN EL ÁREA CENTRAL DE LA PLATA.

Apropiación del espacio en contextos de densificación habitacional y verticalización edilicia.

Arq. Arq. Nadia Freaza

Director: Mg. Arq. Laura Cristina Aón

Co-Director: Paulo Chiesa

2019, La Plata, Argentina 
TRANSFORMACION DEL PAISAJE URBANO EN EL ÁREA CENTRAL DE

\section{LA PLATA.}

Apropiación del espacio en contextos de densificación habitacional y verticalización edilicia.

Tesista: Arq. Arq. Nadia Freaza

Director: Mg. Arq. Laura Cristina Aón

Co-Director: Paulo Chiesa

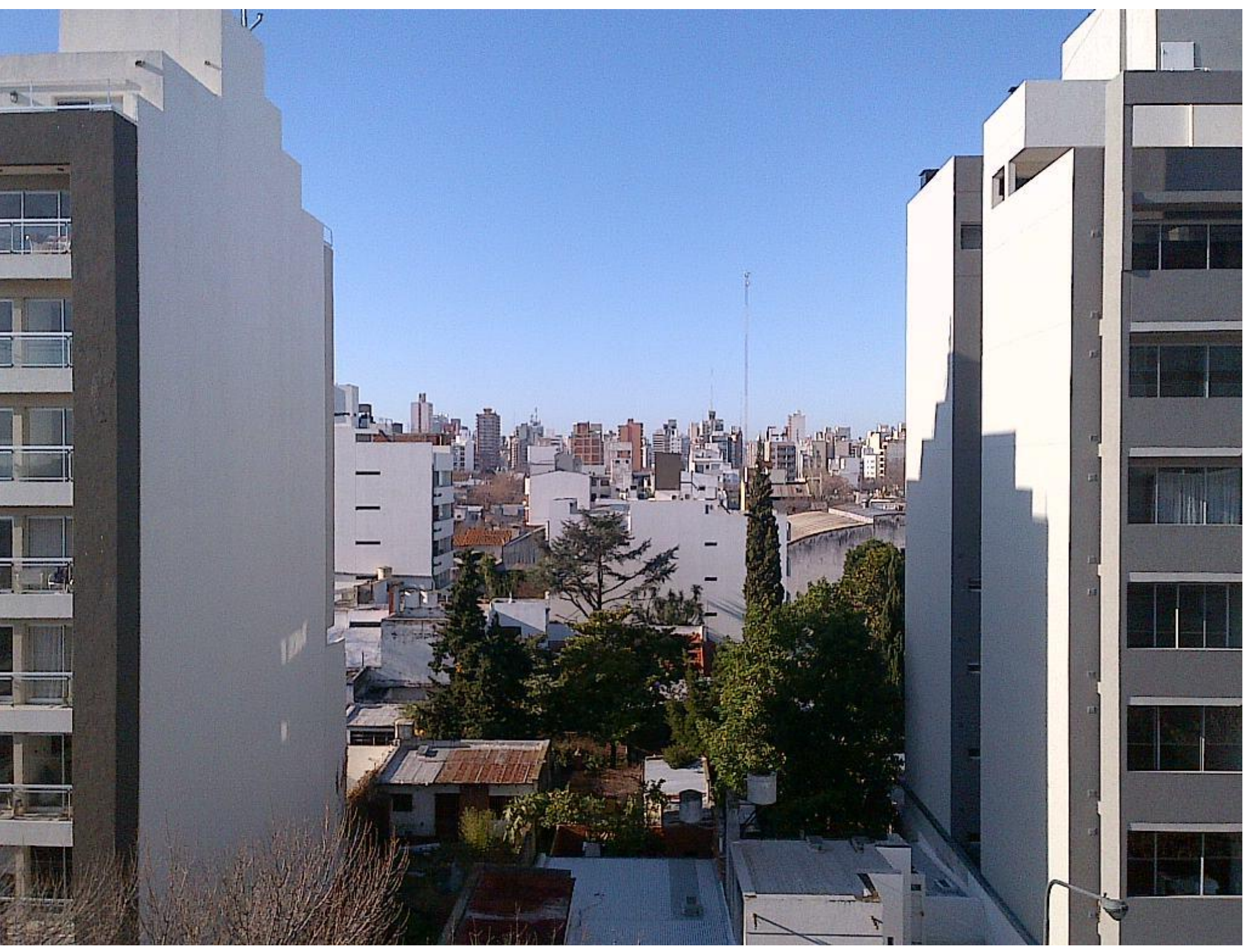

La Plata, Argentina

Septiembre de 2019 


\section{Resumen}

El presente trabajo de tesis de maestría aborda el estudio de la transformación del paisaje urbano del área central de La Plata, que produjo el proceso de densificación y verticalización edilicia que se desplegó entre los años 2004 y 2014, analizando los efectos de este proceso en la apropiación social del espacio urbano por parte de los habitantes. El análisis parte de entender al paisaje urbano, como un concepto complejo, que integra componentes materiales y componentes simbólicas, que es dinámico y está en constante transformación. Dicha transformación es impulsada en este caso por procesos de crecimiento edilicio y reemplazo de viviendas unifamiliares por multifamiliares y en altura, que modifican de manera abrupta el paisaje consolidado, ese lugar conocido, con el que los habitantes han construido en el tiempo, relaciones afectivas de apego que se ven alteradas por la densificación.

La hipótesis que guía la investigación plantea que el proceso de densificación a partir de la verticalización edilicia en el área central de la ciudad de La Plata provoca cambios del paisaje urbano que producen el quiebre de los procesos de apropiación de la población histórica con su entorno. El objetivo principal busca analizar la transformación del paisaje urbano del área central La Plata, provocada por el proceso de densificación habitacional a través de la verticalización edilicia y su incidencia en los procesos de apropiación del espacio urbano.

Para dar respuesta a los objetivos e hipótesis, se diseña y aplica una metodología de abordaje combinado, con métodos cuantitativos, cualitativos y espaciales, que permiten abordar de manera integral el estudio de las transformaciones materiales y simbólicas del paisaje urbano de la ciudad. Se trabaja en dos zonas del área central de la ciudad de La Plata, donde se registran y analizan las componentes materiales y simbólicas en el periodo en estudio, y se reconocen diferentes procesos de transformación del paisaje. 
Las conclusiones señalan las causas de estas diferencias y los efectos de mediano plazo. Se observan los procesos ligados a dos modelos urbanos diferentes dentro de una misma ciudad: una tendiente a la configuración espacial y social más individualista con rasgos metropolitanos y otra más colectiva, basada en la puesta en valor del espacio colectivo como espacio de uso, con calidad ambiental. En cuanto a la hipótesis del trabajo, se verifica que los cambios materiales de la densificación habitacional inciden en los procesos simbólicos de identificación y valoración del paisaje urbano, los cuales pueden desencadenar el quiebre de los procesos de apropiación del espacio en el área central de La Plata.

Palabras claves: Paisaje urbano - Densificación habitacional - Verticalidad edilicia Apropiación del espacio 


\section{Abstract}

This master thesis work addresses the study of the transformation of the urban landscape of the central area of La Plata, produced by the process of densification and building verticalization that was deployed between 2004 and 2014, analyzing the effects of this transformation process in the social appropriation of the urban space by the inhabitants. The analysis starts from understanding the urban landscape, as a complex concept, which integrates material components and symbolic components, and that is dynamic and in constant transformation. This transformation is driven in this case by processes of building growth and replacement of single-family homes with multifamily and height, which abruptly modify the consolidated landscape, that known place, with which the inhabitants have built in time, emotional relationships of attachment that are altered by densification.

The hypothesis that guides the research suggests that the densification process from the building verticalization in the central area of the city of La Plata causes changes of the urban landscape that cause the rupture of the appropriation processes of the historical population with its environment. The main objective seeks to analyze the transformation of the urban landscape of the central area of La Plata, caused by the process of housing densification through building verticalization and its impact on the processes of appropriation of urban space.

To respond to the objectives and hypotheses, a combined methodology approach is designed and applied, with quantitative, qualitative and spatial methods, which allow a comprehensive approach to the study of the material and symbolic transformations of the urban landscape. It works in two areas of the central area of La Plata city, where the material and symbolic components of the period under study are recorded and analyzed, and different landscape transformation processes are recognized. 
The conclusions indicate the causes of these differences and the medium-term effects. The processes linked to two different city models within the same city are observed: One tending to the more individualistic spatial and social configuration with metropolitan features and another more collective, based on the value of the collective space as a space of use, with environmental quality. Regarding the work hypothesis, it is verified that the material changes of the housing densification affect the symbolic processes of identification and appreciation of the urban landscape, which can trigger the rupture of the processes of appropriation of space in the central area of La Plata.

Keywords: Urban landscape - Housing densification

Building verticality - Space appropriation 


\section{Índice}

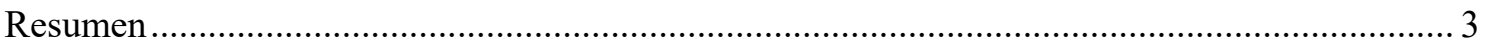

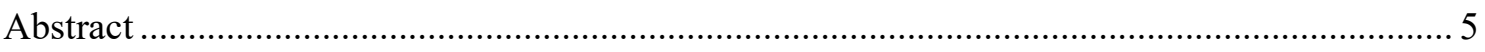

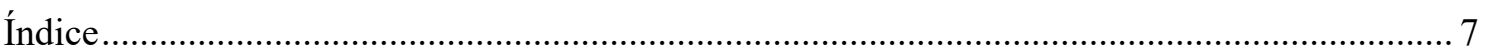

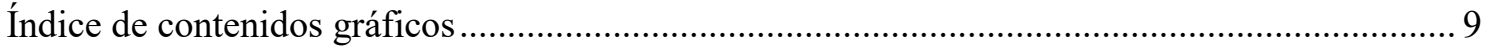

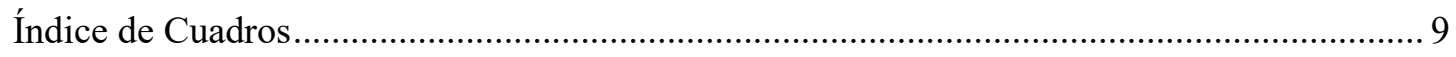

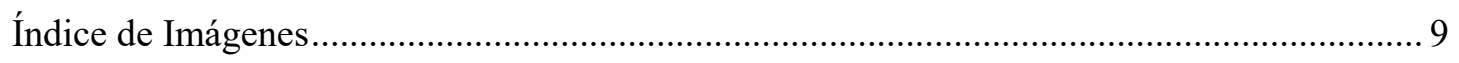

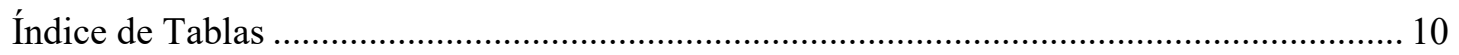

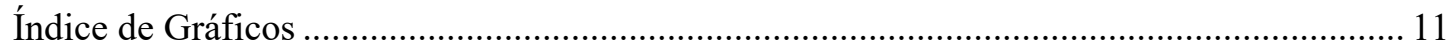

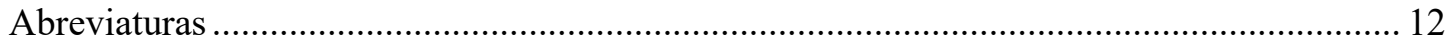

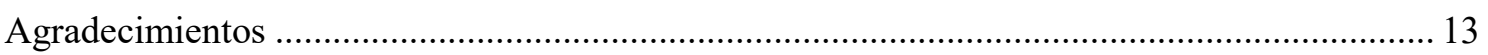

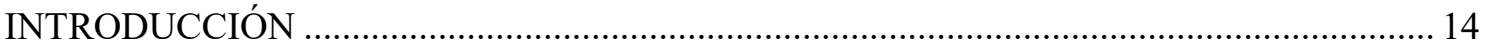

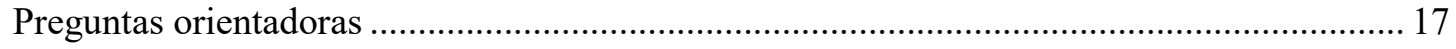

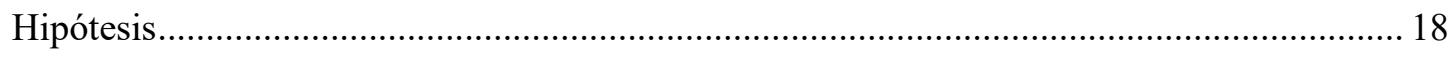

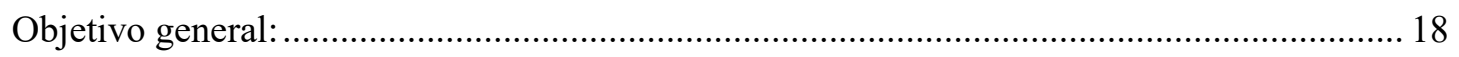

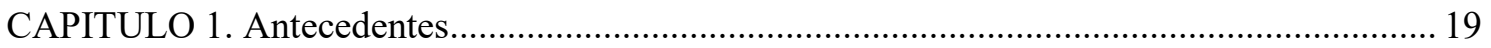

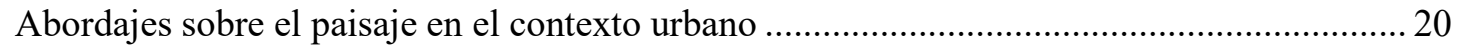

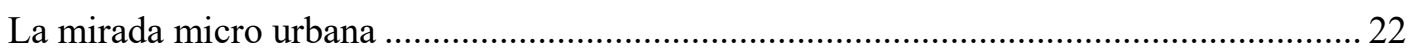

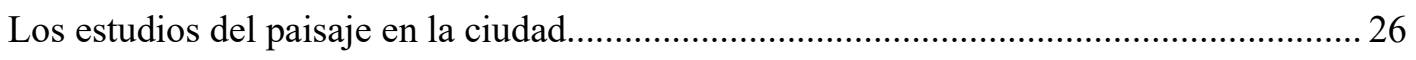

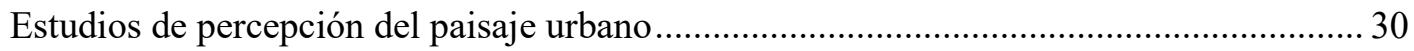

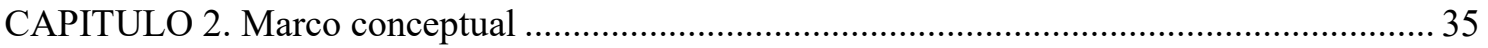

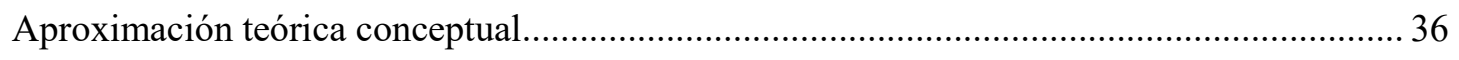

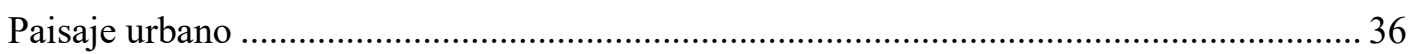

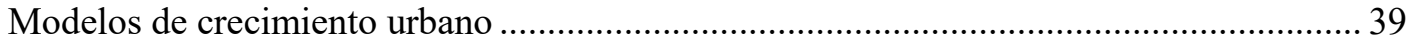

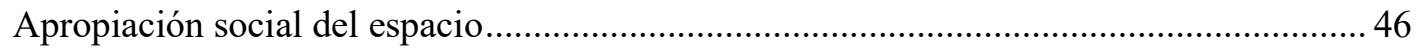

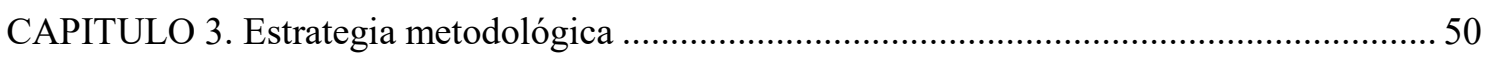

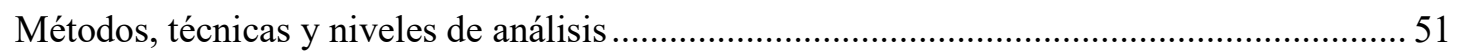

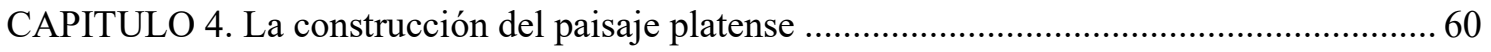


Dos direcciones en la configuración del paisaje platense 61

Expansión y horizontalidad 62

Densificación y verticalidad. .72

CAPITULO 5. La componente material de paisaje 80

Lo tangible y cuantificable en el paisaje . 81

Caracterización y cuantificación de la componente material en la Zona Norte 82

Caracterización y cuantificación de la componente material en la Zona Sur. .90

Dos etapas del proceso de densificación. .98

CAPITULO 6. La componente simbólica del paisaje. 101

Lo simbólico, la identidad y la apropiación. 102

Percepción de la componente simbólica en la zona norte 103

Percepción de la componente simbólica en la zona sur 109

Dos procesos de apropiación en áreas centrales

CAPITULO 7. Análisis de resultados

Componentes del paisaje y sus relaciones. 120

Morfología y tipología en el espacio construido 121

Dinámica y composición del espacio público 125

Transformación y apropiación del paisaje urbano 129

REFLEXIONES FINALES.

ANEXOS Y BIBLIOGRAFIA.

Anexo catalogo patrimonial de la ciudad de La Plata

Anexo Análisis demográfico 150

Anexo Análisis demográfico 151

Bibliografía 152 


\section{Índice de contenidos gráficos}

\section{Índice de Cuadros}

Cuadro 1. Esquema teórico-conceptual de paisaje. Fuente: Elaboración propia 2019. 39

Cuadro 2. La ciudad entendida como sistema. Fuente: Kullock (1994) 40

Cuadro 3. Esquema conceptual propuesto. Fuente: Elaboración propia 2019. 45

Cuadro 4. Síntesis del abordaje teórico. Fuente: Elaboración propia 2019. 49

Cuadro 5. Esquema de elaboración de variables de la componente material. Fuente: Elaboración propia 2019.

Cuadro 6. Esquema de elaboración de variables de la componente simbólica. Fuente:

Elaboración propia 2019 56

Cuadro 7. Síntesis de la propuesta metodológica. Fuente: Elaboración propia 2019

Cuadro 5. Síntesis analítica de los procesos y componentes producidos en el área central.

Fuente: Elaboración propia 2019.

\section{Índice de Imágenes}

Imagen 1. Modelo de la estructura y del desarrollo de la ciudad latinoamericana. Fuente:

Borsdorf (2003)....

Imagen 2. Ubicación geográfica de La Plata y datos poblacionales Año 2014. Fuente:

Elaboración propia en base a datos censo INDEC (2010)

Imagen 3. Estructura urbana, usos y distribución de la población de los periodos analizados.

Fuente: Elaboración propia en base a Frediani (2010)

Imagen 4. Elementos de la estructura urbana según plano fundacional. Fuente: Elaboración propia en base a Garnier (1994) .

Imagen 5. Paisaje urbano y tipologías de vivienda, etapa fundacional 1882-1930. Fuente:

Elaboración propia en base a relevamiento Google Earth y página web: Fotos históricas de La

Plata......

Imagen 6. Paisaje urbano y tipologías de vivienda, periodo 1930 - 1970. Fuente: Elaboración propia en base a relevamiento Google Earth y página web: Fotos históricas de La Plata.

Imagen 7. Paisaje urbano y tipologías de vivienda, periodo 1970-2003. Fuente: Elaboración propia en base a relevamiento Google Earth y página web: Fotos históricas de La Plata. .71

Imagen 8. Edificaciones Nuevas Ejes de desarrollo edilicio en La Plata 2004-2014. Fuente: Elaboración propia en base a relevamiento Google Earth. 
Imagen 9. Oferta de departamentos a la venta, planta tipo y unidades funcionales. Fuente:

Elaboración propia en base a relevamiento en página web SIOC

Imagen 10. Paisaje urbano y tipologías de vivienda, periodo. 2004-2014. Fuente: Elaboración propia en base a relevamiento Google Earth y página web: Fotos históricas de La Plata. 77

Imagen 11. Análisis de composición del paisaje, superposición de torres y medianeras. Fuente: Elaboración propia, fotos del autor 2018.

Imagen 12. Recorte espacial: Área central y zonas testigo seleccionadas. Fuente: Elaboración propia 2019

Imagen 13. Aparición de edificaciones en altura y pérdida de arbolado en una manzana, comparación año 2004-2014. Fuente: Elaboración propia en base a relevamiento de Google Earth.

Imagen 14. Perfil urbano zona norte, año 2014. Fuente: Elaboración propia en base a trabajo de campo y relevamiento de Google Earth.

Imagen 15. Aparición de edificaciones en altura y pérdida de arbolado en una manzana, comparación año 2004-2014. Fuente: Elaboración propia en base a relevamiento de Google Earth.

Imagen 16. Perfil urbano zona sur, año 2014. Fuente: Elaboración propia en base a trabajo de campo y relevamiento de Google Earth.

Imagen 17. Inventario de bienes patrimoniales catalogados. Fuente: Elaboración propia en base al catálogo de edificios patrimoniales de la Municipalidad de La Plata

\section{Índice de Tablas}

Tabla 1. Esquema de niveles de aproximación y matriz de datos. Fuente: Elaboración propia en

Tabla 2. Dimensiones y variables de la componente material.

Fuente: Elaboración propia 2019

Tabla 3. Dimensiones y variables de la componente simbólica.

Fuente: Elaboración propia 2019

Tabla 3. Variación de población, hogar y vivienda en el área central de La Plata. Fuente: Elaboración Propia en base a Proyección censo 2001 y 2010, INDEC.

Tabla 4. Comparación de variables de espacio construido de la zona norte. Fuente: Elaboración propia en base a trabajo de campo y relevamiento de Google Earth.

Tabla 5. Comparación de variables de espacio público de la zona norte. Fuente: Elaboración propia en base a trabajo de campo y relevamiento de Google Earth.

Tabla 6. Comparación de variables de organización social de la zona norte. Fuente: Elaboración propia en base a trabajo de campo y datos censo $\operatorname{INDEC~}(2001,2010)$ 
Tabla 7. Comparación de variables de espacio construido de la zona sur. Fuente: Elaboración propia en base a trabajo de campo y relevamiento de Google Earth.

Tabla 8. Comparación de variables de espacio público de la zona sur. Fuente: Elaboración propia en base a trabajo de campo y relevamiento de Google Earth.

Tabla 9. Comparación de variables de organización social de la zona sur. Fuente: Elaboración propia en base a trabajo de campo y datos censo $\operatorname{INDEC~}(2001,2010)$.

Tabla 10. Relación entre el espacio construido y organización social en ambas zonas. Fuente:

Elaboración propia en base a trabajo de campo y relevamiento Google Earth.

Tabla 11. Relación entre el espacio construido y no construido en ambas zonas. Fuente:

Elaboración propia en base a trabajo de campo y relevamiento Google Earth.

Tabla 12. Matriz de comparación de percepción Fuente: Elaboración propia en base a entrevistas.

\section{Índice de Gráficos}

Gráfico 1. Reconocimiento de Identidad y límites del barrio en la zona norte. Fuente:

Elaboración propia en base a entrevistas semiestructurada.

Gráfico 2. Palabras que utilizan para descripción el paisaje los entrevistados de la zona norte.

Fuente: Elaboración propia en base a entrevistas semi-estructurada.

Gráfico 3. Reconocimiento y valoración del paisaje del espacio privado densificado en la zona norte. Fuente: Elaboración propia en base a entrevistas semiestructurada y fotografías del autor.

Gráfico 4. Reconocimiento y valoración del paisaje del espacio público zona norte. Fuente:

Elaboración propia en base a entrevistas semiestructurada y fotografías del autor.

Gráfico 5. Apropiación de espacios colectivos y actividades del barrio, zona norte. Fuente:

Elaboración propia en base a entrevistas semiestructurada.

Gráfico 6. Reconocimiento de Identidad y límites del Barrio en la zona sur. Fuente: Elaboración propia en base a entrevistas semiestructurada.

Gráfico 7. Palabras que utilizan para descripción el paisaje los entrevistados de la zona sur.

Fuente: Elaboración propia en base a entrevistas semi-estructurada.

Gráfico 8. Reconocimiento y valoración del paisaje del espacio privado densificado zona sur.

Fuente: Elaboración propia en base a entrevistas semiestructurada y fotografías del autor. .... 112

Gráfico 9. Reconocimiento y valoración del paisaje del espacio público zona sur. Fuente:

Elaboración propia en base a entrevistas semiestructurada y Fotografías de la autora 
Gráfico 10. Apropiación de espacios colectivos y actividades del barrio, zona sur. Fuente: Elaboración propia en base a entrevistas semiestructurada.

\section{Abreviaturas}

Av. - Avenida

CABA - Ciudad Autónoma de Buenos Aires

C.I.A.M - Congreso Internacional de Arquitectura Moderna

GIS- Sistema de información geográfica (SIG en español o GIS en inglés)

Est. - Estacionamiento de automóvil

Ha.- Hectárea

Hab.- Habitantes

INDEC- Instituto Nacional de Estadística y Censos

IIPAC- Instituto de investigaciones y políticas del ambiente construido.

IPHAN- Instituto do Patrimonio Histórico y Artístico Nacional de Brasil.

OMS- Organización Mundial de la Salud

ONU- Organización de las Naciones Unidas

UNESCO- La Organización de las Naciones Unidas para la Educación, la Ciencia y la Cultura.

m2 - Metro Cuadrado 


\section{Agradecimientos}

GRACIAS a mi familia, Teresa, Carlos, Fernando, Chela y Myriam, a la que le debo todo.

GRACIAS a mis amigas, Luciana, Julieta, Ana Laura, Karina, Elisa, Daniela, Rocío, Mariana, Irina y Analía, las que me contienen y apoyan siempre.

GRACIAS a los compañeros del IIPAC, con quienes compartimos el trabajo y las risas.

GRACIAS a la Universidad Pública, orgullosa de haber caído aquí. Y al Sistema Científico Nacional que apuesta a un mejor país formando profesionales y apoyando la innovación y producción nacional.

GRACIAS a mis directores, que guiaron en este camino y a quienes sin serlo me escucharon, leyeron y orientaron en todo el proceso.

Por último, GRACIAS a Camilo, el motorcito de mi vida. 


\section{INTRODUCCIÓN}

El presente trabajo aborda el estudio de la transformación del paisaje urbano del área central de La Plata, a partir del proceso de densificación y verticalización edilicia que se desplegó entre los años 2004 y 2014, analizando los efectos de este proceso de transformación en la apropiación social del espacio urbano por parte de los habitantes. El análisis parte de entender al paisaje urbano como un concepto complejo que integra componentes materiales y componentes simbólicas, y que es dinámico y está en constante transformación. Dicha transformación es impulsada en este caso por procesos de crecimiento edilicio y reemplazo de viviendas unifamiliares por multifamiliares y en altura, que modifican de manera abrupta el paisaje consolidado, ese lugar conocido, con el que los habitantes han construido en el tiempo relaciones afectivas de apego que se ven alteradas por la densificación.

En este sentido, los estudios urbanos se han concentrado en analizar las transformaciones urbanas producidas principalmente por procesos de crecimiento expansivo, sin abundar en otras formas de crecimiento. Asimismo, dentro de los estudios que incluyen procesos o modelos de crecimiento por densificación se pueden encontrar dos enfoques principales: los que abarcan la "macro escala" y los que focalizan en la "micro escala" urbana. Entre éstos últimos se pueden encontrar trabajos que profundizan en las particularidades de los procesos de densificación, desde las tipologías arquitectónicas implicadas y las condiciones ambientales del contexto hasta la introducción del concepto de paisaje con el foco puesto en la experiencia de transitar y habitar los espacios urbanos desde un enfoque paisajístico y fenomenológico.

Los paisajes urbanos, tangibles en la composición de edificios en altura que recortan y caracterizan el perfil de las ciudades contemporáneas, no solo evidencian una particular forma de configuración espacial, sino que exponen maneras particulares de producir ciudad, las cuales condicionan la forma de ver y experimentar el espacio urbano. El estudio de los diversos impactos 
que pueden ejercer los procesos de verticalización resulta relevante, principalmente en Latinoamérica en el contexto de cambio de los patrones de urbanización evidenciados en las últimas décadas del siglo $\mathrm{XX}^{1}$. Estos procesos de densificación evidencian una tendencia a la verticalización de las áreas centrales, la cual impulsa un nuevo crecimiento de la población en áreas centrales o como lo expresa Carrión, F. "una vuelta al centro" (Carrión, 2010). Dicho cambio, en el patrón de crecimiento urbano resulta positivo ya que la densificación de las áreas centrales de ciudades consolidadas, que vienen siguiendo una tendencia de crecimiento expansivo, resulta una manera de reorientar el crecimiento urbano hacia el modelo compacto de ciudad, como modelo de sustentabilidad. De acuerdo con las ideas de Salvador Rueda (2003) se establece un modelo compacto, complejo y diverso, como un modelo urbano tendiente a reducir la insustentabilidad urbana, desde el punto de vista funcional, energético, ambiental y social.

En este sentido, el estudio de la forma que toman estos procesos resulta central para revisar a tiempo las actuales estrategias de crecimiento urbano y sus posibles consecuencias, sus variables críticas, instrumentos y herramientas de planificación. A fin de conocer los potenciales daños y/o mitigar los efectos de la insustentabilidad en la ciudad, apuntando a un equilibrio entre los procesos económicos, las necesidades sociales y las consideraciones ambientales ${ }^{2}$.

Al respecto es posible afirmar que las actuales políticas urbanas que favorecen la verticalización en áreas centrales, no siguen las reglas de las ciudades compactas, complejas y diversas que define Salvador Rueda, sino que siguen las reglas del mercado inmobiliario, que impactan en todo el sistema urbano, afectando no solamente las componentes materiales de la configuración espacial, sino también las componentes simbólicas relacionadas a la identidad y la apropiación del espacio

\footnotetext{
${ }^{1}$ El cambio en el patrón de urbanización se relaciona a dos factores principalmente, por un lado, a los cambios demográficos, que combinan descenso del crecimiento poblacional y aumento de la urbanización; y por el otro, a los procesos de globalización, que producen una tendencia a la concentración a nivel local en énclaves de conexión global. (Carrión, 2010)

${ }^{2}$ El concepto desarrollo sustentable emerge como una propuesta conceptual holística que articula al menos tres dimensiones: la económica, la ambiental, la social, para lograr un desarrollo que satisfaga las necesidades del presente sin comprometer la capacidad de las generaciones futuras para satisfacer sus propias necesidades. Comisión Mundial del Medio Ambiente y del Desarrollo (CMMAD) de las Naciones Unidas 1987.
} 
urbano a través de la historia. Ambas componentes del sistema urbano, tanto los materiales como las simbólicas, componen y caracterizan el paisaje urbano.

Para abordar el estudio de los efectos de la densificación en la apropiación del espacio desde el enfoque del paisaje, es necesario incorporar al estudio de la dimensión simbólica, entendiendo que el paisaje es la representación de un medio socialmente construido y apropiado con componentes materiales, que refieren a la configuración del paisaje, y componentes simbólicos, que aluden a las significaciones que tienen una realidad material para un sujeto en una cultura determinada. De esta manera, el paisaje como concepto operacional, no solo da cuenta del proceso histórico de configuración espacial, sino que, está dando cuenta de los procesos actuales de calificación, valorización y diferenciación que ejercen los actores en la configuración urbana (Tella \& Silva, 2010).

En este sentido, el paisaje urbano entendido así, permite incorporar a la ecuación de sustentabilidad, la subjetividad social que construye la identidad colectiva de la ciudad. Al respecto es posible afirmar, que las transformaciones tales como el incremento abrupto de población y de espacio construido, modifca el paisaje urbano de manera tal que repercute en los procesos de apropiación del espacio (Jacobs, 1961).

La irrupción de tipologías de elevada altura y densidad dentro de un tejido de características opuestas, trae aparejado una mayor presión sobre el área, sobre los servicios y redes, sobre la circulación del automotor, sobre los valores del suelo y los alquileres con incrementos especulativos y desplazamiento de usos y población consecuentemente (Tella, Cañellas, Muñoz, \& Natale, 2011). Estos procesos de cambio suponen una pérdida de referencia de la población con su hábitat, la cual incide en la pérdida de identidad del barrio y en la pérdida de calidad de vida, estableciendo una relación de vulnerabilidad urbana frente a las presiones del sector económico proactivo y la inacción o repliegue del Estado.

La ciudad de La Plata es un exponente de dichos procesos urbanos, que implicaron fuertes transformaciones del paisaje de la ciudad. A partir del año 2003 se inició un periodo de 
recuperación económica que generó capacidad de ahorro en los sectores medios y medio altos, buena parte de la cual fue a financiar al mercado inmobiliario como reaseguro en construcción de viviendas. De esta manera, se evidenció un incremento del parque habitacional ${ }^{3}$, en particular crecimiento de edificios en altura. El trabajo propone indagar la transformación del paisaje a partir del proceso de densificación habitacional del área central de la ciudad de La Plata, con el propósito de dimensionar sus efectos sobre las componentes materiales y simbólicas que forman el paisaje urbano.

Para el abordaje de este estudio se proponen dos conceptos principales, paisaje urbano, y apropiación del espacio, que van a orientar la construcción de categorías operativas que permitan dar cuenta de las transformaciones producidas por la densificación habitacional de áreas centrales. Asimismo, será necesario distinguir, observar y analizar las componentes materiales y no materiales y sus relaciones, a efectos de reconocer la incidencia de la densificación de la ciudad, en los procesos de apropiación del espacio urbano por parte de sus habitantes. Para ello se parte de una serie de interrogantes que ayudan a orientar la investigación y estructurar un conjunto de hipótesis y objetivos de trabajo.

\section{Preguntas orientadoras}

¿Qué elementos y/o características paisajísticas son afectados por el proceso de densificación habitacional? ¿Cuáles son reconocidas por los habitantes del sector?

¿Cómo se ve afectada la apropiación, la identificación de los habitantes con el lugar en transformación? ¿Qué pasa cuando se rompen las relaciones de identidad y pertenencia de los habitantes de un barrio con su entorno?

¿Hasta qué punto es factible la transformación del paisaje urbano mediante procesos de densificación habitacional de áreas centrales sin que los habitantes pierdan las relaciones de

\footnotetext{
${ }^{3}$ Informe de Dataurbis, 2014.
} 
identidad y pertenencia con el lugar? ¿Qué elementos o caracteres paisajísticos son necesarios preservar?

\section{Hipótesis}

El proceso de densificación a partir de la verticalización edilicia en el área central de la ciudad de La Plata provoca cambios materiales y simbólicos del paisaje urbano que producen el quiebre de los procesos de apropiación de la población histórica con su entorno.

\section{Objetivo general:}

Analizar la transformación del paisaje urbano del área central La Plata, provocada por el proceso de densificación habitacional a través de la verticalización edilicia y su incidencia en los procesos de apropiación del espacio urbano.

\section{Objetivo Particular:}

Analizar el proceso de densificación habitacional de La Plata, a partir de la producción del parque edilicio y sus características de morfología y tipología.

Dimensionar los cambios materiales provocados por la verticalización edilicia y su incidencia en el paisaje urbano.

Investigar la apropiación social del espacio urbano a partir de analizar la percepción de los habitantes sobre el proceso de densificación y su valoración. 
CAPITULO 1. Antecedentes 


\section{Abordajes sobre el paisaje en el contexto urbano}

El paisaje urbano por definición es un paisaje en transformación, es un paisaje vivo tensionado por procesos que son propios del medio urbano. Entre ellos los procesos de crecimiento, y particularmente los procesos de densificación, son los que impactan de manera más contundente ya que inciden en el paisaje consolidado de las áreas centrales de las ciudades. De manera que resulta valioso para el estudio del paisaje urbano, el análisis de los enfoques tomados por los estudios urbanos en relación a la densificación habitacional, que incorporen un enfoque paisajístico o ligado al espacio urbano en relación a la experiencia urbana del sujeto.

En este sentido, si bien es posible afirmar la existencia de una significativa producción de literatura que aborda el estudio de los procesos de crecimiento urbano, cabe señalar que los procesos de crecimiento por densificación no son los más desarrollados. Se encuentran estudios que analizan los procesos de densificación, pero que no integran sus análisis con el estudio del paisaje. De la misma manera se encuentran estudios que abordan el paisaje urbano en las áreas centrales, pero que no hacen foco en la incidencia de los procesos de densificación.

Se pueden destacar estudios de los centros históricos urbanos y de los procesos de gentrificación en áreas densificadas o en procesos de densificación. Esta línea de trabajo analiza los procesos de transformación de un espacio urbano deteriorado a partir de la reconstrucción o rehabilitación de edificios, que provoca un aumento de los alquileres o del coste habitacional en estos espacios, proceso que trae consigo un desplazamiento poblacional (Pacione, 1990).

Igualmente se encuentran trabajos como los auspiciados por la UNESCO, que se ha preocupado entre otras cosas, por las áreas centrales históricas y las transformaciones de los paisajes patrimoniales. En esta línea se encuentran estudios que destacan el valor del patrimonio urbano 
como motor de desarrollo y cohesión social, y trabajos que elaboran medidas para la conservación del patrimonio urbano.

Más allá de estos pocos ejemplos, las investigaciones urbanas se han preocupado predominantemente por los procesos de expansión más que por la transformación que producen los procesos de densificación de áreas centrales consolidadas. En este contexto y para elaborar un análisis de los estudios de paisaje urbano antecedentes, que sea útil a la presente investigación, se toma la categorización que adopta E. Soja (2004) para investigaciones urbanas mediante la cual distingue los estudios de la micro escala y de la macro escala.

La macro escala es la que aborda al conjunto urbano como unidad de análisis, y la micro escala aborda pequeños recortes territoriales, estudios de barrio y de los objetos arquitectónicos. Los primeros hacen hincapié en los procesos de estructuración de la ciudad en su totalidad. En este grupo se encuentran estudios sobre crecimiento urbano desde una mirada general de los procesos económicos y sociales que impulsan o modifican patrones de urbanización y estudios y propuestas de modelos de crecimiento.

La micro escala, en cambio, es aquella en la que se da importancia a "la vista desde abajo" (Soja, 2004), estudios que hacen hincapié en la experiencia de transitar y habitar los espacios urbanos incorporando un enfoque paisajístico y fenomenológico. Entre estos, se pueden encontrar estudios que profundizan en las particularidades de los procesos de densificación, analizando desde las transformaciones materiales de las tipologías arquitectónicas implicadas y condiciones ambientales resultantes, hasta las transformaciones de la experiencia urbana y del paisaje.

En este marco, la revisión bibliográfica se centra en los trabajos del segundo grupo, con un enfoque de la micro escala. Entre estos trabajos se encuentran las críticas contextualitas del Team X (1960) y la Tendenza italiana (1960) que mantenían el foco en la búsqueda de la tipología "adecuada". Estos trabajos enfocan sus críticas y propuestas de crecimiento a partir de tipologías edilicias con preocupaciones por la experiencia urbana del sujeto. Por su parte la crítica sociológica de Jane Jacobs (1961) pone de relieve las relaciones entre la transformación de la 
ciudad material y sus efectos en el tejido social. En su trabajo Kevin Lynch (1960) focaliza sobre la experiencia urbana del habitante y la legibilidad del espacio urbano.

A dichos estudios se incorpora la línea de estudios sobre el paisaje, desde las primeras definiciones de la geografía, las reinterpretaciones desde las perspectiva existencialista, y los trabajos actuales como los de Montañés Gómez (2001) y Donadieu (2006) que vinculan los procesos de desarrollo urbano edilicio con la construcción de identidad colectiva; o los escritos de Nogué (2007) y Muxi (2009) que destacan los procesos de transformación territorial en relación a los procesos sociales de apropiación; hasta los trabajos de Sabaté Bell (2005) y Magnoli (2010) sobre la importancia del paisaje entendido como patrimonio cultural, como constructo que vincula a las personas con los hechos y las huellas de su historia. Ligados a estos estudios se incorporan trabajos que abordan el aspecto metodológico del análisis sobre la experiencia perceptiva del paisaje. Desde la teoría de la Gestalt de la escuela de Frankfurt (1910), hasta los estudios fenomenológico de la escuela de Chicago (1960).

\section{La mirada micro urbana}

El enfoque micro urbano reúne estudios que hacen hincapié en la experiencia de transitar y habitar los espacios urbanos. Se pueden encontrar estudios que profundizan en las particularidades de los procesos de densificación, desde las tipologías arquitectónicas implicadas y condiciones ambientales hasta los paisajes urbanos resultantes y la experiencia urbana en dichos paisajes.

Ya Simmel (1903) advirtió que la vida en las grandes ciudades expone a sus habitantes a tal variedad e intensidad de estímulos, que produce en ellos una reacción de estrés. Estas ideas negativas sobre la vida en la ciudad fueron continuadas y desarrolladas por algunos representantes de la Escuela de Chicago. Por ejemplo, a partir de éstas y otras reflexiones Louis Wirth (1938) elabora una teoría del urbanismo en la que trata de establecer un número limitado de 
características identificativas de la ciudad, así como las consecuencias que se derivan de ellas. Las características que este autor considera fundamentales para definir la vida urbana son el tamaño de la población, la densidad y la heterogeneidad de población y actividades.

Otros autores orientan sus trabajos al análisis desde "la parte" para abordar el "todo urbano", y trabajan la escala de barrio, tejido urbano ${ }^{4}$, calles o tipologías arquitectónicas como unidad elemental de la ciudad. Dentro de esos autores se encuentran algunos encuadrados en el Movimiento Moderno, que proponen resolver problemáticas urbanas desde el desarrollo de tipologías arquitectónicas específicas. A partir de la noción de "tabula rasa", el contexto urbano se vuelve abstracto e indeterminado, no un contexto de límites y vacíos, sino de masa y espacio libre. La composición de los paisajes era construida por elementos sueltos en el manto de la naturaleza desde una vista a vuelo de pájaro, en contraposición a las perspectivas urbanas clásicas con una visión peatonal siempre encuadradas por elementos arquitectónicos o vegetación (Monedero, 2008).

Luego de la segunda guerra mundial, la destrucción de gran parte de las ciudades europeas ofreció la posibilidad de materializar los modelos del Movimiento Moderno, que hasta entonces habían sido formulaciones teóricas. Como se pudo plasmar en Unités d'habitation, que reúne los principios de maximización del uso del suelo a partir de la verticalización de los edificios de vivienda, liberando el suelo permitiendo una permeabilidad y relación de la construcción con el entorno urbano. Sin embargo, la aplicación indiscriminada de los principios funcionalistas motivó la pérdida sistemática del patrimonio urbano de numerosas ciudades europeas (Monedero, 2008). La pérdida de identidad cultural que la urbanización utópica había traído consigo, comenzó a ponerse de manifiesto en la década del 50 e incluso dentro del Movimiento Moderno surgió un grupo de voces críticas.

\footnotetext{
${ }^{4}$ Tejido urbano denota la estructura u organización de los componentes perceptibles que conforman una ciudad.
} 
Si bien las críticas apuntaban a lo funcional, se comienza a evidenciar la preocupación por los elementos urbanos que aportan identidad. Los arquitectos agrupados bajo el nombre de Team $\mathrm{X}^{5}$, pretendían superar el modelo simplista del núcleo urbano de la ciudad funcional, con una idea compleja que incluya el concepto de $\operatorname{lugar}^{6}$ y que responda a la necesidad de identidad compartida colectivamente. Se oponían al reduccionismo extremo de la arquitectura moderna, que no incorporaba espacios o elementos que permitiesen generar asociación, identidad, y flexibilidad. Dentro de este grupo se destacan los Smithson ${ }^{7}$ quienes reflexionaron sobre los espacios de relación entre edificios, ya no como meros espacios de transición, sino como elementos en sí mismos, capaces de poseer significado e identidad. Proponían la transición desde las 4 categorías “corbuserianas" funcionalistas a las 4 categorías fenomenológicas, casa, calle, distrito y ciudad. Pretendían así rescatar el valor de la ciudad, como elemento material y matriz, este es un cambio sustancial de enfoque.

Mientras el movimiento moderno centra el análisis en las funciones urbanas, otros grupos recuperan el tema de la forma urbana y los elementos primarios determinantes del tejido de la ciudad, vinculados a la memoria colectiva y la forma de producción de ciudad (Monedero, 2008). Aldo Van Eyck, perteneciente al TEAM X, considera que la arquitectura moderna había provocado un corte en la producción tradicional de ciudad, para él no debía haber división entre arquitectura y urbanismo, entre lugar y forma edificada, ya que son parte de un continuo.

En la misma línea, Aldo Rossi, quien se inscribe en la corriente italiana Tendenza, estudia la ciudad por las partes que la componen, concibe la ciudad como arquitectura, lo que lleva a la recuperación del concepto de "tipología". La ciudad plasma la memoria colectiva en las tipologías edificatorias, y "son éstas las que determinan la forma urbana y los elementos de la ciudad" (Rossi, 1982/ 1966). Esto invierte el sentido que tenía la vivienda dentro del pensamiento

\footnotetext{
${ }^{5} \mathrm{El}$ Team X fue un grupo de arquitectos, participantes de una serie de reuniones que se iniciaron en julio de 1953 en el congreso C.I.A.M. IX, desde donde introdujeron sus doctrinas al urbanismo. Compuesto por Jaap Bakema, Georges Candilis, Giancarlo de Carlo, Aldo Van Eyck, Alison y Peter Smithson entre otros. Plantean una nueva propuesta, a partir de tres grandes principios: Asociación, Identidad, y Flexibilidad.

${ }^{6}$ El concepto de lugar apela a formas cualitativas de ocupación del espacio que dan cuenta de los diferentes procesos de apropiación territorial. (Aón \& Frediani, 2010)

${ }^{7}$ Pareja de arquitectos ingleses que escribieron teoría del urbanismo y formaban parte del Team X.
} 
urbano racionalista, y lo reconcilia con la trama parcelaria y la forma de propiedad existente. La teoría de la forma urbana que desarrolla Rossi, transformó el criterio moderno aportando a la construcción de códigos de indicadores constructivos como forma de planificación normativa del crecimiento urbano (Monedero, 2008).

En 1961 Jane Jacobs publica "Muerte y vida en las grandes ciudades americanas", donde refuerza la crítica a la planificación racionalista por producir espacios anti-urbanos, homogéneos y sin referencia. La crítica sociológica de Jacobs hace hincapié en los impactos sociales de construir entornos tan alejados del paisaje de la ciudad tradicional. Para la autora cuando se aplica en un área una política urbana, no solamente se afecta el espacio material, sino también a sus habitantes y a su tejido social, de manera que, junto con echar abajo casas viejas, los habitantes son desarraigados, en un proceso de repliegue de relaciones de pertenencia con su hábitat, lo cual produce un efecto negativo directo sobre la calidad de vida.

El fenómeno que señala Jacobs se potencia en la ciudad globalizada, como señala Ghal ium (en Michellod, 2001), en la ciudad globalizada las referencias peligran frente a las transformaciones impuestas por una cultura globalizada, que provocan una crisis de identidad del tejido social local. Estos análisis ligan la dimensión material del paisaje con la dimensión simbólica donde se anclan las referencias de identidad colectiva.

Estas críticas están influenciadas por la corriente existencialista, que se enfoca en el análisis de la condición humana, en la existencia o experiencia del individuo en el mundo y en la percepción de dicha existencia. Esta nueva perspectiva cambia el foco en los análisis urbanos y sus métodos de investigación hacia la mirada del habitante, involucrando las subjetividades y las condiciones ambientales que se generan. 


\section{Los estudios del paisaje en la ciudad}

La incorporación de la idea de paisaje urbano en los estudios urbanos está ligada a un enfoque crítico que corre el foco de interés en la ciudad como objeto de estudio, hacia la relación entre el la sociedad y su contexto urbano. En este sentido, el concepto de paisaje urbano se constituye desde una visión integral alejada de visiones esteticistas o naturalistas del paisaje. Si bien la noción de paisaje es una idea en disputa, es posible reconocer distintas interpretaciones según la disciplina.

La reciente investigación de Rubilar Muñoz, desarrolla una síntesis de enfoques disciplinares para el concepto de paisaje, donde se señala que, para los geógrafos el paisaje se define como la descripción de la realidad física o cultural de un lugar. Para los ecólogos, el paisaje es una abstracción de las condiciones del medio, como "un conjunto de indicadores que facilitan la lectura o interpretación de un sistema ecológico subyacente" (González Bernáldez en Rubilar Muñoz, 2015). Para los arquitectos el paisaje se percibe como el espacio proyectable, al respecto Isachenko agrega una idea que apela a la transdisciplina, precisando que "cuando se analiza aisladamente el paisaje resulta parcialmente explicado" (Isachenko en Rubilar Muñoz, 2015). Esta idea permite reconocer una forma de abordar conceptos complejos territoriales y paisajísticos simultáneamente preocupándose por su materialidad tanto como por su identidad, evocando al vínculo entre la realidad material y el tejido social. En este sentido, es necesario superponer todos los conocimientos para conformar la totalidad que logre otorgar el consenso disciplinar en su contextualización y conceptualización (Rubilar Muñoz, 2015).

De acuerdo con K. Jensen (2018), “en los estudios sobre paisaje se observan dos tendencias teóricas fuertes: la idealista y la materialista." Por un lado, la tendencia idealista sostiene que el paisaje es una construcción mental estética, a partir de reconocer en él algo artístico mediante códigos culturales. En este grupo se encuentra A. Roger (2007), quien sostiene que hablar de 
paisaje implica necesariamente un tipo de apreciación estética, lo que él define como proceso de “artealización”.

Por otro lado, la tendencia materialista afirma que el paisaje también se refiere al producto físico, cierta disposición de elementos en una parte de la superficie terrestre, es una porción material del ambiente natural y su representación. Esta forma de concebir al paisaje tuvo su origen en la geografía alemana del siglo XIX. Carl Sauer, establece la primera definición formal de paisaje en 1925, como un espacio resultado de diferentes formas asociadas, tanto físicas como culturales. Sauer resalta los agentes culturales en la formación de los rasgos visibles de una región, pero les quitaba importancia a los aspectos subjetivos del paisaje, considerando que el paisaje era "un área objetiva que debía ser estudiada científicamente a través de la observación"

En las décadas del sesenta y setenta, se divide el enfoque de los geógrafos. Por un lado, la geográfica clásica con un enfoque explícitamente positivista y espacial. Por otro lado, la geografía crítica, con un enfoque influenciado por filosofías humanísticas, el existencialismo y la fenomenología. En este marco, los estudios sobre paisaje cobran una nueva perspectiva distinta a la conceptualización moderna de paisaje que lo entendía como escenario de la naturaleza, asignándole un valor de contemplación (Aliata \& Silvestri, 2001). El cambio conceptual incluye a la persona en la naturaleza, y conjuga la experiencia del espacio vivenciado con la carga histórica de producción del territorio. Asociado a conceptos como "lugar", entendido como espacio que da cuenta de los diferentes procesos de apropiación territorial expresada en elementos técnicos y simbólicos (Aón \& Frediani, 2010), el paisaje constituye un ámbito en el que los seres humanos construyen vínculos, aspiraciones, significados, emociones que puede constituirse en objeto de interpretación.

El estado de la cuestión actual reconoce que el paisaje, como concepto, desempeña un papel importante en los campos cultural, ecológico, medioambiental y social, contribuye a la formación de las culturas locales y es una componente fundamental del patrimonio natural y cultural. Estas 
ideas se recogen en el Convenio Europeo de Paisaje ${ }^{8}$, que define paisaje como "cualquier parte del territorio tal como la percibe la población, cuyo carácter sea el resultado de la acción y la interacción de factores naturales y/o humanos" (Consejo de Europa, 2000). Esta noción de paisaje suprime la concepción esteticista, e incorpora el valor histórico, identitario y simbólico para los habitantes, a partir de la noción de percepción.

El reconocido investigador catalán, experto en urbanismo y patrimonio, Joaquín Sabaté Bell (2005) utiliza el termino Paisaje Cultural para referirse a la transformación del paisaje natural por la acción de la sociedad. Esta noción de paisaje cultural, también utilizada por UNESCO $^{9}$ y la IPHAN $^{10}$, implica una extensión del significado tradicional de paisaje, sujeto a una representación visual, un recorte espacial, o una descripción literaria, desplegando un significado integrado que incluye a la naturaleza y la sociedad amalgamados el uno con el otro, modo de producción y formación social y económica, en relación a la cultura, tecnología, hábitos y prácticas sociales, simbólicas y valores espirituales (Magnoli, 2010).

Dentro de esta concepción se han desarrollado legislaciones y documentos de conservación del patrimonio, como las diversas cartas de paisaje de Latinoamérica (Brasil, Bolivia, Chile, México, etc.) o el Convenio europeo del paisaje. Esta nueva concepción permite la introducción del concepto de Paisaje en la Planificación Urbana y el Desarrollo Urbano (Sabaté Bell, 2005) (Nuñez, 2010) (Erlij, 2004), a partir del cambio de concepción de las políticas territoriales y culturales que visualiza al paisaje cultural como instrumento de desarrollo.

Otra línea de análisis profundiza en la relación del espacio producido con y por los habitantes que lo ocupan a partir del "proceso de apropiación" de los espacios. "El paisaje es también un reflejo del poder y una herramienta para establecer, manipular y legitimar las relaciones sociales y de poder" (Nogué, 2007). Dicha conceptualización hace énfasis en el proceso en el que intervienen

\footnotetext{
${ }^{8}$ El Convenio europeo del paisaje (2000), lanzado por el Consejo de Europa, tiene como objetivo fundamental promover la protección, gestión y ordenación de los paisajes europeos.

${ }^{9}$ UNESCO, Organización de las Naciones Unidas para la Educación, la Ciencia y la Cultura.

${ }^{10}$ IPHAN, Instituto do Patrimonio Histórico y Artístico Nacional de Brasil.
} 
actores sociales que entran en disputa por el territorio, proceso que se cristaliza en el paisaje urbano específicamente, como una imagen visual cargada de dimensiones histórica y simbólica.

El estudio realizado por Muxi, Z. (2009) profundiza en la transformación estética del paisaje urbano a partir de los cambios funcionales de los espacios de consumo, en los que el paisaje se homogeneiza y los ciudadanos se convierten en consumidores, que en términos de la autora construye una identidad difusa basada en la pura imagen. Al respecto, el investigador urbanista Guillermo Tella (2010) señala que en la actualidad el capital privado, organiza el territorio y desarrolla las áreas a partir de procesos de calificación del espacio, valorización del territorio y diferenciación espacial, procesos que generan en la ciudad "nuevas relaciones entre espacio, poder e identidad, tales relaciones se expresan mediante símbolos, mediante elementos materiales que comunican ideas o valores que contribuyen a ordenar y configurar el territorio, la población y las inversiones".

La tesis sobre paisaje e imaginarios urbanos realizada por Zuñiga Méndez, C. M. (2014) ahonda en la transformación del paisaje urbano de las áreas centrales de las ciudades, área que entiende como un elemento relevante de la cultura urbana y un factor de integración del habitante con la ciudad por su valor histórico (Zúñiga Méndez, 2014). En su trabajo toma a Mantecón, A. R. (2005) quien señala que en la tradición de estudios de los centros históricos se han considerado tanto elementos tangibles (atributos urbanísticos y monumentales y sus condiciones materiales) como intangibles (actividades productivas, formas de vida y elementos de la cultura popular) para su análisis. Dichos enfoques incorporan la componente simbólica del paisaje, y analizan cómo, los procesos de apropiación del espacio transforman el paisaje urbano imponiendo nuevos símbolos y significaciones y eliminando otros.

Es por esto que las transformaciones en el paisaje urbano son importantes de reconocer, ya que estudios realizados desde la sociología, refieren a "procesos subjetivos anclados en experiencias y marcas simbólicas y materiales" ligadas a un territorio específico (Jelin, 2002). Esas marcas 
son las que componen el paisaje urbano y le otorgan significado, y cuando perduran en el tiempo constituyen lo que llamamos "patrimonio".

Estos argumentos encuentran fundamento en los escritos de Lefebvre, y particularmente en el libro "La producción del espacio" (Lefebvre, 1974), en el que reconoce que el espacio es protagonista, no un mero escenario de la realidad social. Para el autor tanto el proceso de producción del espacio como el espacio en sí mismo -espacio social producido- son un único elemento inseparable (Baringo Ezquerra, 2013). Su teoría unitaria del espacio, entiende de manera unificada el espacio físico (la naturaleza), el espacio mental (las lógicas y las abstracciones formales) y el espacio social (el espacio de la interacción humana), ámbitos que han sido estudiados por separado por diversas disciplinas y que Lefebvre propone analizar de manera conjunta para poder exponer y decodificar el espacio.

Esta manera de entender espacio físico y espacio social se emparenta con los estudios de paisaje, que definen al paisaje como la relación entre naturaleza y cultura, en la que confluyen y se retroalimentan ambos factores. En ella podemos reconocer las dimensiones materiales y simbólicas del territorio y del paisaje.

\section{Estudios de percepción del paisaje urbano}

La asimilación conceptual del concepto de paisaje al de ciudad y la consolidación de su incorporación definitiva en los estudios urbanos, ha dado lugar a diversas propuestas metodológicas para su abordaje. En este sentido, los estudios de paisaje incorporaron distintos aportes sobre prácticas y métodos de evaluación de la percepción, modos de interacción y preferencias del paisaje (Goenaga, 2001). Estas experiencias de percepción de la imagen se remontan a la teoría de la Gestalt desarrollada en 1910 en la escuela de Frakfurt, que permite 
profundizar en el análisis de la imagen paisajística, ya que considera que la imagen completa es más compleja que la suma de las partes. Esta conceptualización transciende el análisis por partes, formas, colores, vegetación, etc.; para analizar la imagen en su conjunto.

Hacia final de los años '60, en Inglaterra y Estados Unidos, se presentan dos líneas en los estudios de evaluación del paisaje. Por un lado, la aproximación global, que parte de que la impresión visual de un paisaje es resultado de la interacción entre las partes. Por otro lado, una aproximación analítica, considera que la calidad visual del paisaje resulta de la sumatoria de la calidad visual de las componentes. A partir de los años '70, la investigación se centra en el individuo desde lo conceptual y lo metodológico. Los estudios de percepción del paisaje incorporan aspectos sensoriales, al igual que estados de ánimo, satisfacción y apreciación.

En 1960, Kevin Lynch publica su libro "La imagen de la ciudad" sobre legibilidad urbana. En él, aborda la interpretación del espacio por los usuarios, relacionando espacio y percepción. Lynch desarrolla la idea de legibilidad de la forma de la ciudad, para definir la imagen mental que el observador construye de la realidad visual, esto permite conocer qué formas determinan las imágenes y reconocer los elementos constitutivos de dichas imágenes.

A partir de este estudio Lynch (1960) identifica tres componentes de las imágenes mentales: estructura, identidad y significación. A su vez, dentro de la estructura de las imágenes de la ciudad, reconoce cinco tipos de elementos: sendas, bordes, barrios, nodos y mojones. Elementos que caracterizan y cualifican al paisaje, elementos físicos que cargan un significado históricocultural y permiten a los habitantes reconocer al entorno y reconocerse dentro del mismo. Estos enfoques, reconocen la importancia de la experiencia del habitante que vive y construye los espacios de la ciudad, que a su vez está inmerso en procesos económicos políticos sociales y culturales mayores.

Al año siguiente Gordon Cullen publicó su libro “Townscape” (1961), traducido como "El paisaje urbano", en el que expone su método de estudio a partir de la visión serial de un recorrido. Cullen afirmaba que el paisaje de la ciudad provoca sensaciones a quien la recorre, y que no se puede 
tener una única visión, sino que ésta se compone de una sumatoria de secuencias paisajísticas. Este método pone el foco en el análisis del arquitecto, sin poder captar las sensaciones experimentadas por los habitantes de la ciudad, a diferencia del método que desarrolla Lynch, quien se preocupa por detectar las percepciones de los habitantes.

La psicología ambiental aporta otro enfoque, se centra en la relación que existe entre el comportamiento de las personas (individual o social) y el espacio que habitan. Como señala Esparza (2012) si se traza un paralelismo entre la manera de estudiar el comportamiento de las personas y la experimentación del paisaje, es posible entender cómo los habitantes se relacionan con el paisaje.

El paisaje de las áreas centrales de las ciudades tiene un papel en la construcción de un sentido de lugar a partir de comprender el valor del área central desde tres aspectos: i) como punto de encuentro y sociabilidad; ii) como contenedor y expresión de múltiples y simultáneas identidades y iii) como espacio de disputa civil y político (Zúñiga Méndez, 2014). Al respecto Borja y Muxi (Borja \& Muxí, 2001) señalan tres posibilidades de relación simbólica entre centro histórico y habitantes, una que remite al origen de una ciudad; otra a los grupos sociales que lo construyeron; y la última remite a la identidad de una ciudad y sus habitantes por su valor histórico, urbanístico y arquitectónico.

En este sentido, Roger (2007) señala que la apropiación del espacio constituye el anclaje de la componente simbólica del paisaje, a través de este mecanismo se evidencia el pasaje de lo tangible hacia los códigos y criterios a partir de los cuáles se establece la existencia de paisaje o no. Como establece Montañes Gómez (2001) la apropiación del espacio no se refiere sólo a vínculos de propiedad sino principalmente a los lazos subjetivos de identidad y afecto con el territorio. Los sujetos tienen cierta capacidad de incidir en la transformación de su territorio, es así como el espacio queda revestido de las dimensiones política, identitaria y afectiva. Es decir, la apropiación del espacio, como proceso, construye el paisaje como producto. 
Hidalgo Villodres (1998) en su tesis sobre apego al lugar hace una exhaustiva recopilación de conceptos ligados a la idea de un sentimiento especial de las personas por sus lugares de residencia. Al referir al concepto de apropiación del espacio señala que es un proceso que integra los aspectos de acción, imagen, identificación, interacción, proyección, personalización, territorialidad y privacidad. Hidalgo Villodres explica que cuando nos apropiamos de un lugar, actuamos sobre él y lo modificamos a nuestra imagen (Villela Petit, 1976), nos identificamos con ese espacio (Sansot, 1976) y proyectamos sobre él nuestra personalidad (Villela Petit, 1976), interactuamos con otros (Canter, 1977), lo defendemos de posibles agresores y controlamos el acceso a él (Brower, 1980). Para Brower (1980), tanto la apropiación del espacio como el apego al lugar son conceptos subsidiarios de la conducta territorial, y la define como el control sobre un entorno concreto en relación con la ocupación, la defensa y el sentimiento de pertenencia (apego).

Otro concepto que destaca es el de identidad de lugar (place identity), que fue desarrollado por Harold Proshansky (1983), para describir el papel que tienen las propiedades físicas del entorno residencial sobre la estructura de la personalidad. Es decir, cualquier cambio tanto en el ambiente social del sujeto, como en el físico (deterioro del barrio, cambio de residencia, etc.), afectará a la identidad personal del individuo.

En esta línea, Figueras (2002) señala que la posibilidad de identificación con las componentes materiales y simbólicos del entorno supone contribuir a la cohesión interna de los colectivos sociales. Estos fenómenos facilitan comportamientos ecológicamente responsables y la implicación y la participación en el propio entorno. Más aún, la desapropiación constituye un problema urbano crítico, que trae aparejados problemas más complejos que impiden la consolidación de las ciudades como hechos colectivos, perdiendo las ciudades su espíritu original contrario a la lógica rural y propiamente socio urbano.

En este sentido, el análisis de las transformaciones paisajísticas y la percepción de dichos cambios, da pautas para la consideración de políticas urbanas implementadas. Y se constituye 
como la base para la caracterización del modelo implementado y la definición de políticas urbanas que tiendan a la sustentabilidad efectiva o afectiva del modelo de crecimiento urbano.

La revisión construida permite dar cuenta de la relevancia que tiene el estudio de las componentes simbólicas del paisaje urbano en las transformaciones urbanas y en particular, su peso potencial en el diseño de políticas. La búsqueda desplegada para la construcción de esta revisión, también da cuenta de la ausencia de estudios específicos sobre los efectos de los procesos de densificación en los habitantes, así como también da pautas específicas de los vacíos de conocimiento en el tema, los cuáles se toman como insumo para la construcción conceptual y metodológica de la presente tesis. 
CAPITULO 2. Marco conceptual 


\section{Aproximación teórica conceptual}

La construcción del marco teórico se estructura a partir de entender al paisaje urbano en los siguientes sentidos: i) como concepto integral y multidimensional, situado en un contexto territorial específico; ii) como la representación de un medio socialmente construido y tensionado por procesos propios del medio urbano; y iii) como una imagen cargada de símbolos culturales con los que el ciudadano interactúa.

En correspondencia, para entender al paisaje y su concepción en el medio urbano, se profundiza en la noción de paisaje, las dimensiones que lo componen y la relación con el medio urbano.

Para abordar el paisaje urbano y los procesos urbanos que inciden en su transformación, se profundiza en el conocimiento de la noción de ciudad, en la configuración urbana densa-compacta y sus vínculos con las transformaciones materiales del paisaje.

Para comprender el rol simbólico y las relaciones que se establecen en y con el paisaje urbano se profundiza en los procesos de construcción y significación del espacio urbano, y en el impacto de las transformaciones del paisaje respecto a los procesos de apropiación espacial.

Paisaje urbano

Para analizar las transformaciones del paisaje urbano es necesario precisar la definición de paisaje adoptada, en pos de precisar su alcance y aplicación empírica, ya que es un concepto que presenta distintas acepciones según las distintas disciplinas y enfoques que lo trabajan. La 
conceptualización de paisaje que se aborda en esta tesis se distancia de las visiones esteticistas o naturalistas utilizadas en los siglos XVIII y XIX, que vinculaban al paisaje con la contemplación da la naturaleza y valoraciones solamente estéticas. En el marco del paradigma sistémico, las nociones de paisaje no se reducen a la esfera estética o natural, sino que se comprende al paisaje como un concepto integral, que incluye lo ético a lo estético y lo cultural a lo natural.

Sin embargo, la diversidad de enfoques y disciplinas, que abordan el paisaje, implican una variedad en conceptualizaciones que como señala Aón (2001) se diferencian por la manera en la que consideran al individuo dentro de la noción de paisaje. La visión naturalista planteada desde la ecología considera al paisaje como áreas homogéneas de organismos que interactúan con su entorno, en la mayoría de los estudios el factor humano se considera como parte de la complejidad ecológica.

Desde la geografía humana Santos (1996) define paisaje como todo lo que nuestra visión alcanza a ver, las formas, los volúmenes, los colores, movimientos, olores, sonidos, etc.; y más adelante agrega que el paisaje es resultado de sumas y restas sucesivas, una especie de marca de la historia del trabajo, de las técnicas. El autor considera al paisaje como un palimpsesto, como un mosaico, pero con un funcionamiento unitario. Sabaté Bell (2005) recupera los estudios de geografía cultural, y utiliza el concepto de Paisaje Cultural como el resultado de la acción de un grupo social sobre un paisaje natural, entiende que la cultura es el agente, la naturaleza el medio y el paisaje cultural el resultado.

Desde otra visión, se hace referencia a los procesos de percepción de dicha realidad material, anclando la reflexión en torno a la persona, su mirada y los procesos cognitivos que actúan en el proceso de lectura de la imagen paisajística. En este sentido, A. Roger (2007) rescata la materialidad del paisaje, ya que considera que el paisaje parte de algo tangible pero que no se reduce a ello, y alcanza sistemas simbólicos, códigos y criterios de los individuos y de las sociedades. 
J. Nogué (2007) define el paisaje como un producto social, como la proyección cultural de una sociedad en un espacio determinado, producto de una relación entre la sociedad y la naturaleza, que se establece a partir de un conjunto de sistemas técnicos y simbólicos. Esta perspectiva entiende al paisaje como una construcción social, una forma de ver el mundo, que se corresponde con una ideología y con una determinada forma de apropiación del espacio, es un reflejo del poder en el territorio y una herramienta para establecer y legitimar relaciones sociales.

Estos enfoques son complementarios entre sí, la noción de paisaje se constituye como una categoría relacional, que recompone la relación entre cultura y naturaleza, entre sujeto y objeto, entre la razón y sentimiento. Esta interpretación plantea un proceso circular donde la sociedad transforma el medio y el medio condiciona la sociedad y su forma de ver y comprender su entorno.

Desde esta interpretación integral, se entiende el paisaje como la representación dialéctica de la relación entre medio natural - cultura / cultura - medio natural (para el caso de las ciudades organización económica social y cultural y medio urbano), a través de un proceso histórico y dinámico por el cual la sociedad reconoce el medio y genera las maneras para adaptarlo y adaptarse. Esta dialéctica entre construcción material de la ciudad y construcción de códigos culturales, es lo que Berque (2006) define como "trayección”, el vaivén entre el individuo y su entorno, donde el individuo modifica su entorno y éste a su vez modifica al individuo.

Así, el paisaje urbano puede ser comprendido como, la imagen multidimensional de un proceso de transformación histórico-cultural en un territorio especifico. Categoría que incluye componentes materiales y componentes simbólicos que caracterizan esa relación entre cultura y naturaleza. Es decir, el paisaje de una ciudad está compuesto por componentes materiales como la topografía, el tipo de construcción, la forma, la textura, el espacio vacío, y componentes simbólicas como el significado social de una zona, de un hito, de un edificio, junto con su función y su historia. La clave radica en el vínculo y las interacciones entre dichas componentes (ver Cuadro 1). 


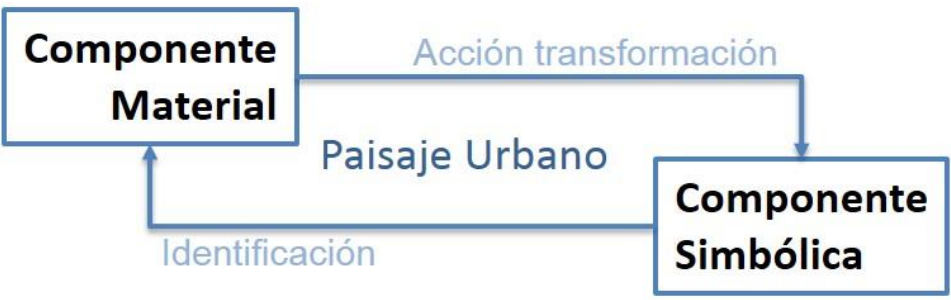

Cuadro 1. Esquema teórico-conceptual de paisaje. Fuente: Elaboración propia 2019.

La noción de paisaje urbano construida para esta tesis, se aleja de las visiones esteticistas, relacionadas con lo pictórico y la contemplación externa de la imagen, así como de la visión ambiental, que relaciona al paisaje con los factores bióticos y abióticos del ambiente natural. La noción de paisaje urbano construida para esta tesis apela al medio urbano, que está en constante transformación, es espacio de construcción de sentido y disputa de poder, contenedora de memoria individual y colectiva, un espacio fenomenológico con un significado percibido y representado (Moya Pillitero, 2011). Entonces, cuando se habla de paisaje urbano, se alude a las representaciones de un medio socialmente construido y apropiado.

\section{Modelos de crecimiento urbano}

Desde la perspectiva de los procesos de crecimiento urbano es necesario precisar el concepto de ciudad y modelos de crecimiento urbano, entre los cuales la densificación es una de las variables necesarias, a fin de explicitar las relaciones con el paisaje urbano y los procesos implícitos en el medio urbano.

La ciudad es entendida como sistema complejo que articula aspectos físicos y sociales, como un producto socio espacial e histórico que contiene múltiples dimensiones: económica, territorial, espacial, física, ambiental, morfológica, funcional, institucional, social y cultural y las relaciones con su entorno (Karol, 2005). La noción de complejidad trasciende la relación lineal entre 
dimensiones, apuntando a comprender la multiplicidad de vínculos y su interdefinibilidad, así como también comprender la evolución temporal, y el comportamiento de los actores. En ésta línea Kullock (1994) (ver Cuadro 2) propone un esquema para interpretar a la ciudad como la relación entre el ambiente y la sociedad y las demandas que mutuamente se generan.

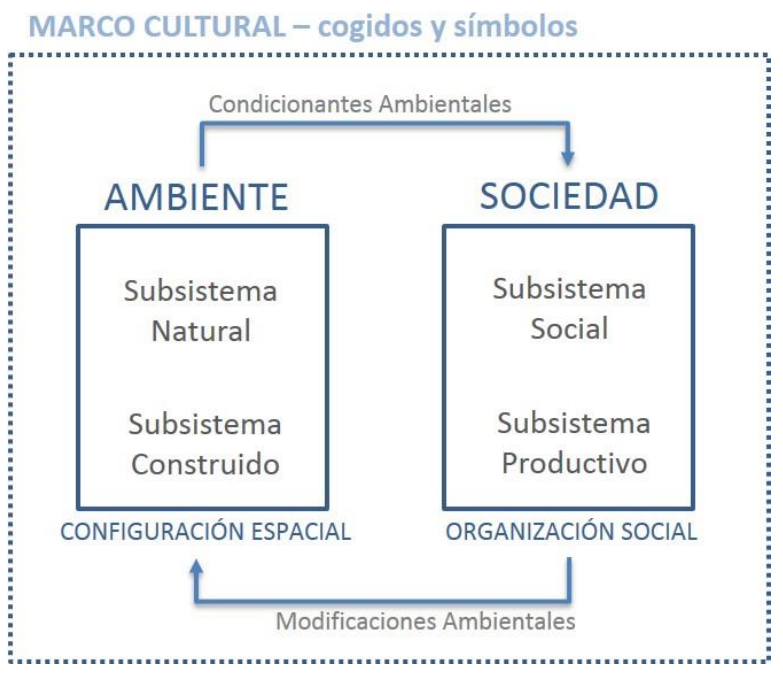

Cuadro 2. La ciudad entendida como sistema. Fuente: Kullock (1994)

En este sentido, se comprende al espacio urbano como un producto cultural derivado de una práctica social, entendiendo cultura como la suma de los procesos sociales de producción y reproducción, construcción, ocupación, dominio y apropiación, que expresan lógicas sociales contradictorias. Como señala Lefebvre (1974), "la esencia de los procesos de urbanización radica en la expansión incesante y revolucionaria de los procesos de circulación y socialización mediante la producción de infraestructuras que organizan al mismo tiempo el espacio y la sociedad". En este sentido, las transformaciones históricas de las ciudades expresan las formas de interacción entre la naturaleza y la cultura, es por eso que los procesos espaciales que se desarrollan dentro del ámbito urbano, no se pueden estudiar ni entender, escindidos de los procesos sociales.

En este sentido, para entender los procesos de crecimiento de la ciudad es necesario hacer referencia a los modelos de estructuración urbana y ponerlos en relación con los procesos históricos-culturales de cada momento. Borsdorf (2003) señala cuatro formas claramente discernibles que adopta la ciudad latinoamericana a lo largo del proceso histórico, y en relación 
con las características culturales de cada periodo, caracterizada por anillos concéntricos, sectores y manchones periféricos, (Ver Imagen 1). Parte de la estructura colonial compacta y organizada a partir de las normas de los países colonizadores, seguida por la urbanización de primera fase identificada por una expansión lineal coincidente con los procesos de migración europea, la urbanización de segunda fase caracterizada por una polarización urbana coincidente con la migración interna campo-ciudad. En estos modelos la centralidad es clara y potente, concentrando la mayor parte de los usos y recursos de la ciudad.
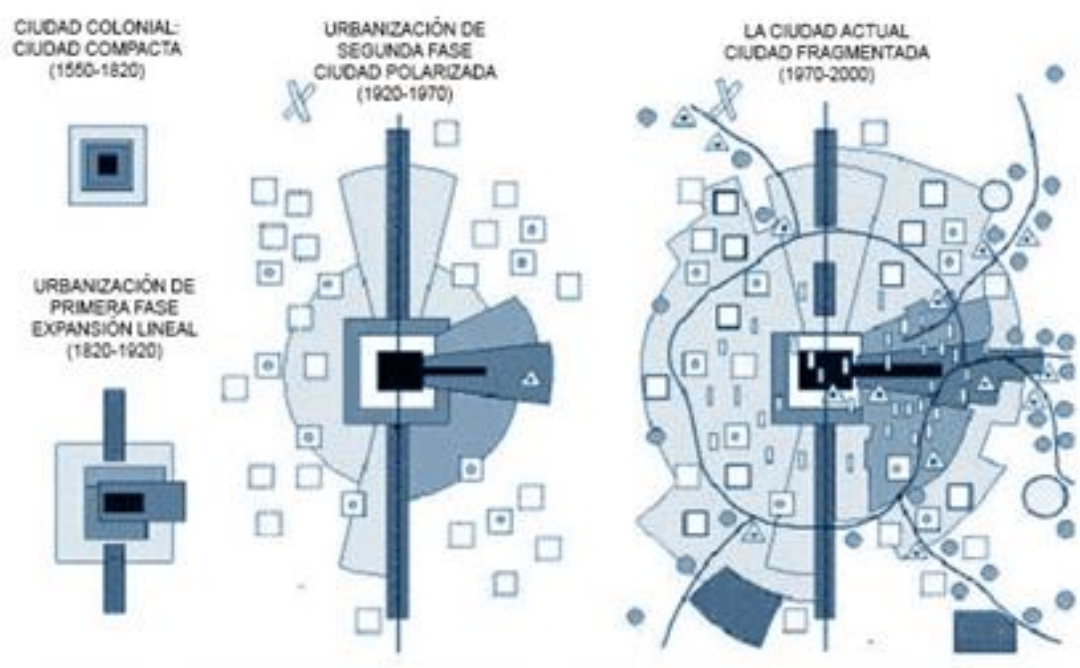

Imagen 1. Modelo de la estructura y del desarrollo de la ciudad latinoamericana. Fuente: Borsdorf (2003)

Y, por último, una fase denominada ciudad en islas definida por la fragmentación urbana. En esta última fase la centralidad se multiplica, aparecen nuevas centralidades, de carácter secundario, pero que comienzan a acumular usos y recursos. Centralidades que experimentan transformaciones que se dan en el marco del proceso de restructuración del sistema capitalista del último cuarto del siglo XX. Que incluye una reestructuración económica sobre los mercados laborales, que provoca cambios en la organización y el funcionamiento de la ciudad, financiarización de la economía mundial, en particular del capital inmobiliario altamente especulativo, cambios en la morfología urbana, una tendencia hacia una 'ciudad dual' (Muxi, 2009) o 'ciudad fractal' (Soja, 2004), con modificación de la imagen y el paisaje urbanos (Cicollela, 2010). 
A su vez, en dichos modelos de estructuración urbana se pueden reconocer instancias de los procesos de crecimiento urbano: expansión, consolidación y densificación. Las ciudades se expanden sobre los territorios rurales, con barrios que ocupan la periferia con un patrón de baja densidad y dejan grandes vacíos intersticiales; en otros sectores se dan procesos de consolidación del tejido urbano. Y Simultáneamente, se producen procesos de densificación en zonas consolidadas de la ciudad que coinciden generalmente con las áreas centrales y fundacionales de las ciudades.

En el caso de las ciudades latinoamericanas, el crecimiento se da principalmente por extensión de la superficie urbana hacia la periferia y al mismo tiempo por densificación en áreas centrales. En este contexto, el modelo compacto de crecimiento urbano asociado a la concentración y a la alta densidad urbana se constituye como el modelo más sustentable para el crecimiento urbano. Como señala Rueda (2003) la compacidad permite concentrar y multiplicar los contactos y vínculos que son la esencia de la ciudad como hecho colectivo; y al mismo tiempo que reduce las distancias, el transporte y el consumo de energía derivado.

Sin embargo, dicho proceso de densificación se produce a partir de la emergencia de los capitales inmobiliarios, devenidos de las ganancias extraordinarias producidas por el modelo económico, que provocan especulación y gentrificación de los espacios centrales que no se revierten en la disminución del crecimiento urbano expansivo, sino que en la mayoría de los casos lo incrementa. Procesos apoyados por la economía globalizada que requieren posicionar escenarios locales en el contexto global a partir de énclaves urbanos especializados, y por el supuesto pregonado por los foros internacionales que consideran que el modelo de crecimiento compacto es una de las variables de la sustentabilidad urbana. Desde la visión de la sostenibilidad urbana se considera el modelo compacto como el más eficaz en tanto ahorro en energía y recursos materiales y suelo, la gestión de la distancia, y la preservación del entorno agrícola y natural. Los beneficios asociados a la concentración y la alta densidad urbana, tales como una mayor diversidad de usos, de intercambios, mayor eficiencia relativa y accesibilidad a servicios, sostienen el modelo compacto de crecimiento urbano como el modelo más sustentable. 
Para lograr disminuir la insustentabilidad urbana se requiere de un abordaje sistémico, a partir de tres dimensiones interrelacionadas: la economía, el medio ambiente y la sociedad, e implica pensar estrategias económicas, ambientales y sociales conjuntamente, de manera equilibrada en la búsqueda de una mejor calidad de vida. Esta manera de concebir el desarrollo se inscribe en el marco del pensamiento contemporáneo, que propone una visión holística del mundo, que interpreta el mundo con la sociedad inmersa en los procesos cíclicos de la relación naturalezacultura, asumiendo la interdependencia de los fenómenos.

En el modelo de estructura de la ciudad latinoamericana que plantea Borsdorf (2003), el área central es protagonista, manteniendo las características de centralidad en todo el proceso de crecimiento. Las áreas centrales son, por lo general, las zonas históricas con mayor provisión de servicios y equipamientos, la mayor consolidación del tejido, concentración de actividades y la mayor acumulación de patrimonio arquitectónico y urbano.

Estas áreas, por su condición de centralidad, experimentan procesos característicos que no impactan de la misma manera en otros sectores de la ciudad. Por una parte, el crecimiento del parque habitacional en estas áreas se da predominantemente mediante procesos de densificación habitacional con verticalización edilicia; y por otra, el interés histórico de estos lugares genera procesos paralelos de calificación del espacio y diferenciación espacial, que modifican los valores históricamente sedimentados. Estas transformaciones en la forma de producir el espacio urbano generan cambios en las relaciones de poder e identidad que se despliegan en el paisaje urbano, y se expresan mediante símbolos que comunican ideas y valores relativos a esa centralidad, los cuáles se ven afectados.

Los cambios morfológicos que implica la densificación habitacional de un área urbana central generan profundas transformaciones en la configuración y organización de la ciudad y afectan las características originales del paisaje urbano que son las que califican el espacio, valorizan el territorio y diferencian ese lugar de otros. La construcción de edificios en altura modifica la 
morfología del espacio construido a partir del cambio del perfil urbano y de la intensificación de la ocupación del suelo. Otro aspecto que se modifica es la tipología de vivienda de las construcciones, reemplazando las edificaciones antiguas (viviendas y edificios de referencia urbana) valoradas como patrimonio arquitectónico por sus características, con lo cual se transforma el paisaje de los centros históricos provocando una pérdida de parte de la historia e identidad de la ciudad.

El cambio en el espacio construido incide en la relación con el espacio público: en el aspecto ambiental se ve afectada la relación con los espacios verdes y la presencia de vegetación; en el aspecto de infraestructura, se afecta la movilidad, incrementándose la cantidad de autos que circulan y la demanda de estacionamientos de los nuevos residentes. Funcionalmente se ve afectada la organización del espacio por el incremento de actividades, viviendas y automóviles. Cambia la relación entre el uso residencial y la actividad comercial, los servicios y la oferta cultural y deportiva. El aumento de la densidad de población, la incorporación de nuevo vecinos, las características etarias socio económicas y familiares de los nuevos habitantes del sector, modifica las dinámicas cotidianas, mientras que la alta concentración de habitantes por lote, producto del reemplazo de viviendas unifamiliares por multifamiliares, afecta de manera crítica, la ocupación del espacio público y las relaciones entre habitantes o vecinos. (Freaza \& Aón, 2012).

Si entendemos que el crecimiento urbano es continuo y constante, como la transformación de la sociedad misma, es evidente que el paisaje de la ciudad y sus características cambian conjuntamente. Sin embargo, el crecimiento de las áreas más antiguas e históricas tiene particularidades. El cambio en la forma de producción de espacio residencial central modifica el territorio histórico cambiando, remplazando o eliminando las referencias territoriales de la población, que son los elementos de construcción simbólica del tejido social (Montañez Gómez, 2001). Sin embargo, cuando los paisajes urbanos son sometidos a fuertes presiones urbanísticas en corto tiempo, éstos pierden o cambian radicalmente su discurso y su imaginario, resultando en 
territorios sin discurso y paisajes sin imaginario (Nogué, 2007). Estos procesos actúan a nivel simbólico sobre los nuevos paisajes creando nuevos códigos culturales.

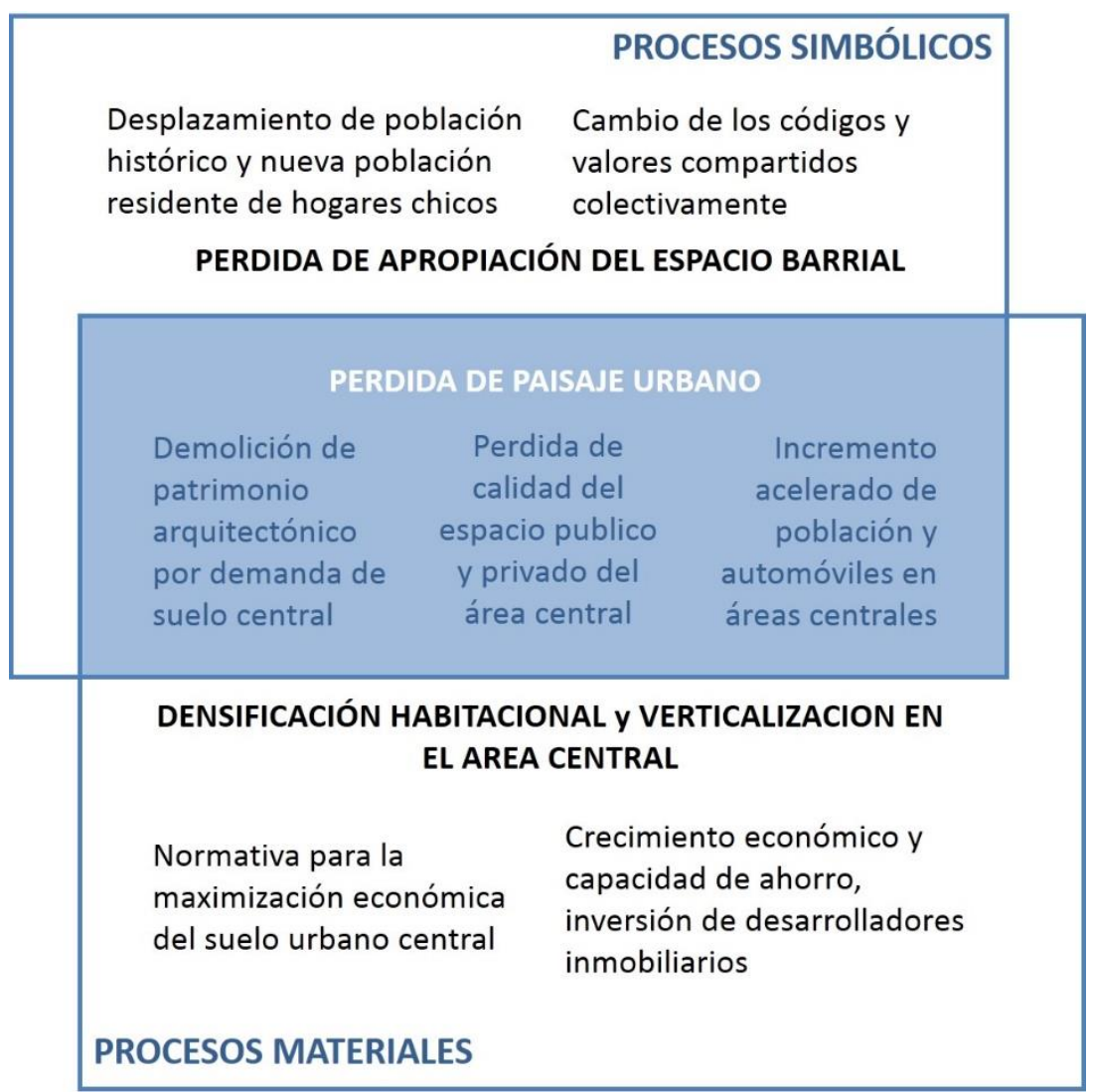

Cuadro 3. Esquema conceptual propuesto. Fuente: Elaboración propia 2019.

En este sentido, el modelo de crecimiento por densificación en áreas centrales, nos permite anticipar cierta relación entre los cambios materiales producidos por la transformación urbana, y su incidencia en los aspectos simbólicos. Los escenarios de densificación de áreas centrales nos permiten reconocer cómo las componentes materiales del paisaje repercuten en la organización social que son fenómenos socio-espaciales ${ }^{11}$ mediante los cuales las personas actúan y se vinculan con el espacio urbano, las componentes simbólicas, la identificación y apropiación social del espacio urbano en transformación (ver Cuadro 3). Para ello es necesario incorporar conceptos que permitan reconocer las relaciones simbólicas entre espacios y el individuo.

11 Los actores intervienen en el territorio mediante 4 tipos de fenómenos socio-espaciales: i) la gestión de la distancia (accesibilidad y distanciamiento), ii) la producción del espacio (nuevos territorios, nuevos paisajes), iii) la dominación del espacio (mapas mentales, representaciones simbólicas del espacio) y iv) la apropiación del espacio (propiedad y posesión, barreras simbólicas). 


\section{Apropiación social del espacio}

Las transformaciones paisajistas producto de procesos de densificación habitacional tienen un efecto innegable sobre las componentes materiales (urbanas), así como también sobre las componentes simbólicas (sociales). Esta idea fue expresada en los años `60 por la periodista urbanista J. Jacobs (1961), en su crítica al urbanismo norteamericano centralista de Robert Moses $^{12}$, denunciando los efectos adversos de aquella política urbana en el tejido social. En su libro, Jacobs dice en su argumento inicial, "escribiré sobre cómo funcionan las ciudades en la vida real, pues solo así conoceremos qué principios urbanísticos y qué prácticas de rehabilitación pueden estimular la vitalidad social" (Jacobs, 1961).

La autora hace alusión a las referencias urbanas y las relaciones cotidianas que nutren al tejido social, si no son tomadas en cuenta por las políticas urbanas intervencionistas, del tipo que sean (viviendas, autopistas, espacios públicos, etc.) se pueden ver afectadas o desbaratadas, pudiendo desencadenar un repliegue de las relaciones sociales y una pérdida de identidad.

En este contexto, comprender las transformaciones urbanas implica no solamente indagar en la transformación material de la ciudad, en la composición del tejido urbano, formas, movimientos y personas; sino también y especialmente, en las relaciones simbólicas entre los espacios urbanos y sus habitantes (Karol, 2013). Como señala Karol (2014), se trata de que lo urbano no puede pensarse sin su obvia y biunívoca conexión con la gente y tramas de relaciones entre todos ellos, su historia, y los significados de las diversas centralidades urbanas y la simbólica de su construcción y apropiación social.

\footnotetext{
${ }^{12}$ Robert Moses (18 de diciembre de 1888-29 de julio de 1981) funcionario público estadounidense quién trabajó principalmente en el área metropolitana de Nueva York, fue el gran impulsor de la planificación centralizada.
} 
En este marco, la apropiación social del espacio se entiende como aquella en que la persona se hace a si misma mediante las propias acciones, en un contexto sociocultural e histórico. Este concepto deviene de los aportes de la psicología ambiental, donde apropiación se concibe como un mecanismo básico del desarrollo humano por el que la persona se "apropia" de la experiencia generalizada del ser humano, lo que se concreta en significados de la realidad. El aporte desde las visiones de la psicología marxista, pone el énfasis en la construcción socio-histórica de la realidad, se apoya en la idea de que a partir de la interiorización de la praxis humana surge la conciencia, de lo interpsíquico a lo intrapsíquico (Vidal Moranta \& Pol Urrútia, 2005).

Este proceso de apropiación presenta dos mecanismos principales, la acción-transformación y la identificación simbólica. Mediante la acción-transformación, los individuos o grupos transforman el espacio dejando su 'huella', marcas cargadas simbólicamente. Y a través de la identificación simbólica, producto de procesos afectivos y cognitivos, la persona y los grupos se reconocen en el entorno y se auto atribuyen las cualidades del entorno como definitorias de su identidad. Como señala Vidal Moranta \& Pol Urrútia (2005:4) el espacio apropiado puede ser considerado como factor de continuidad del Yo, de estabilidad de la identidad y de cohesión de grupo.

Para el enfoque sostenible, la apropiación social del espacio urbano se constituye en una variable significativa en la concepción de lograr una ciudad menos insustentable, ya que la implicación y participación en el propio entorno es lo que logra comportamientos ecológicamente responsables. Para Alderoqui (2002) el vínculo con el lugar explica dimensiones de comportamiento que trascienden lo funcional. En este sentido el paisaje urbano puede ser la clave para el análisis, ya que es una categoría que entreteje dimensiones que incluyen componentes materiales (urbanos) y componentes simbólicos (sociales) que caracterizan esa relación entre cultura y naturaleza.

En este sentido, para Figueras (2002), la posibilidad de identificación con las componentes materiales y simbólicas del entorno supone contribuir a la cohesión interna de los colectivos sociales. Estos fenómenos facilitan comportamientos ecológicamente responsables y la 
implicación y la participación en el propio entorno. Más aún, la desapropiación constituye un problema urbano crítico, que trae aparejados problemas más complejos que impiden la consolidación de las ciudades como hechos colectivos, perdiendo las ciudades su espíritu original contrario a la lógica rural y propiamente socio urbano. Jacobs señala una cita de H. Salsbury, sobre la importancia de las relaciones interpersonales urbanas y su quiebre, ya que "hasta un gueto con historia puede crear una estructura social dando lugar a organizaciones que resuelvan problemas propios" (Jacobs, 1961).

En síntesis, 'lo urbano' no se puede pensar sin conexión con las personas ni con las tramas de relaciones entre todos ellos, su historia, y los significados de las diversas centralidades urbanas y la simbólica de su construcción y apropiación social. Se define el paisaje urbano como, una imagen multidimensional que incluye componentes materiales y componentes simbólicos, representación de un medio socialmente construido y apropiado, a partir de un proceso de transformación histórico-cultural en un territorio específico. Territorio en el que la forma de producir el espacio establece relaciones de poder e identidad, que se despliegan en el paisaje urbano y se expresan mediante símbolos y valores. Y que, en el caso de alteraciones como la irrupción de un proceso acelerado de densificación habitacional de un área urbana central, afecta las características originales del paisaje urbano que son las que califican el espacio, valorizan el territorio y le otorgan su singularidad como valor fundamental.

A partir de estas conceptualizaciones construidas, a continuación se diseña una estrategia metodológica que permita alcanzar el objetivo de analizar la transformación material del paisaje urbano del área central de La Plata, provocada por un acelerado proceso de densificación habitacional que se dio entre 2004 y $2014^{13}$ mediante procesos de verticalización edilicia desplegados por el mercado inmobiliario, a efectos de dimensionar su incidencia en los procesos simbólicos de apropiación del espacio urbano.

\footnotetext{
${ }^{13}$ Tendencia extraída de las estadísticas anuales de superficies de obra aprobada para la construcción, publicadas por la Municipalidad de La Plata
} 


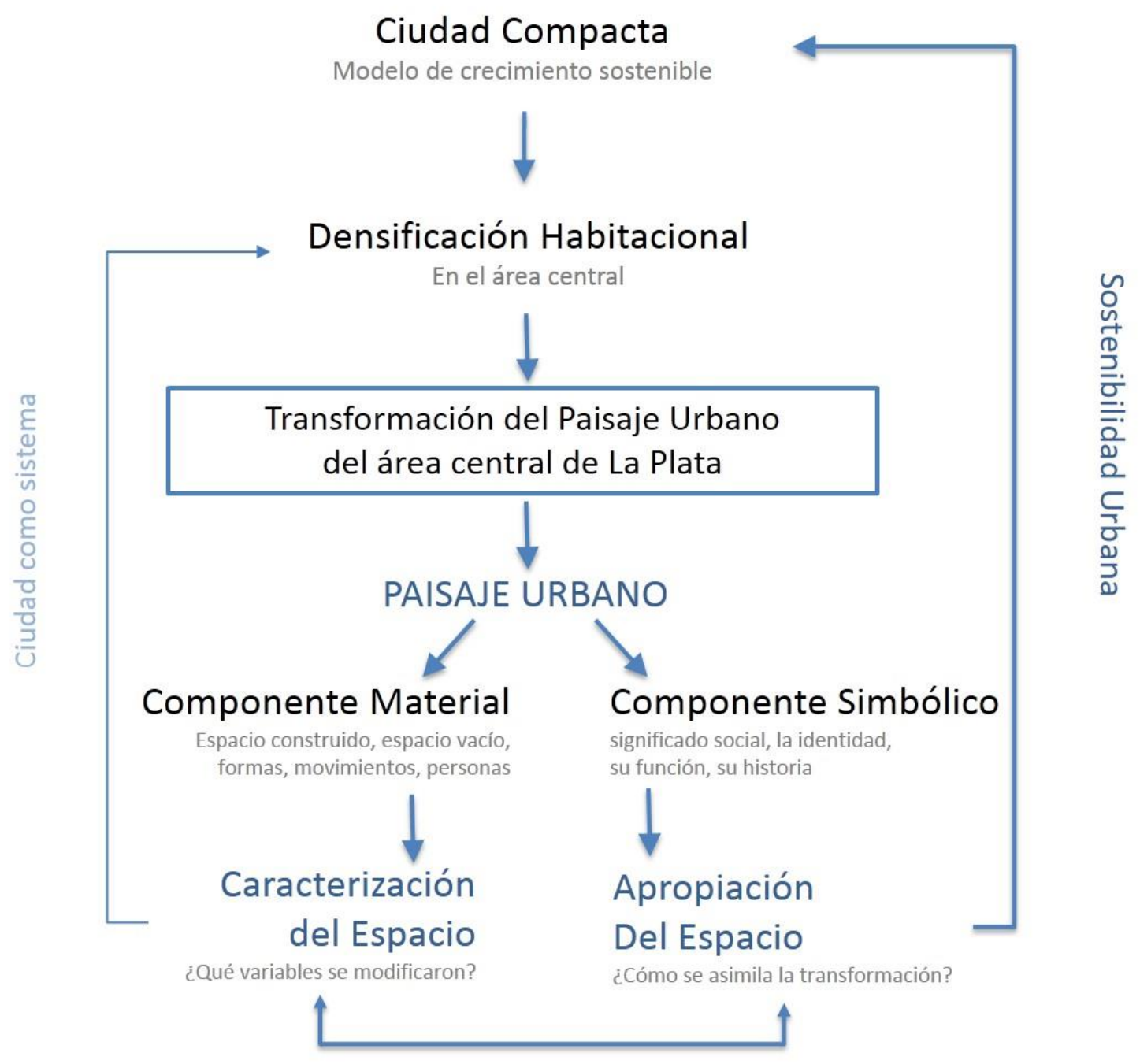

Cuadro 4. Síntesis del abordaje teórico. Fuente: Elaboración propia 2019 
CAPITULO 3. Estrategia metodológica 


\section{Métodos, técnicas y niveles de análisis}

Este trabajo apunta a una investigación de tipo analítica, ya que pretende conocer la transformación material del paisaje urbano derivada de los procesos de densificación y verticalización edilicia, y correlacionar dichas transformaciones con los procesos simbólicos de apropiación del espacio urbano por parte de los habitantes. Para ello se utiliza como herramienta de investigación el estudio de caso, que en esta tesis se trata del caso del área central de la ciudad de La Plata.

Para abordar el objeto de estudio se parte del enfoque conceptual que considera variables cualitativas y cuantitativas que se enmarcan en la teoría de Matriz de datos de Samaja, que organiza un sistema de datos en tres niveles de aproximación (ver Tabla 1). Este esquema permitió aproximarse al tema con distintos niveles de complejidad, desde la contextualización del fenómeno hasta el análisis particularizado del proceso a partir de la precisión de las variables de análisis.

De esta manera se proponen y combinan diversos métodos a fin de abordar los distintos enfoques que plantea el tema de la tesis (ver Cuadro 4), y para lograr un avance en la forma de estudiar el paisaje urbano en transformación. Se entiende necesario adoptar métodos cualitativos, cuantitativos y espaciales, lo que permite analizar el sistema urbano y las transformaciones paisajísticas, ponderando no sólo los datos objetivos del proceso de densificación, sino que permite contrastar y sopesar dichos datos con la percepción de los actores involucrados en el proceso estudiado.

Para ello se realizó un relevamiento de variables físicas mediante la recolección de información con instrumentos de recolección, registro y sistematización de datos primarios, y de sistematización y reprocesamiento de información de fuentes secundarias: datos demográficos y 
cartográficos de origen censal, normativas y reglamentaciones, análisis de estadísticas de construcción y de permisos, investigaciones y notas periodísticas, foto-lectura de imágenes satelitales, etc. Para luego sistematizar los datos primarios y secundarios y elaborar cartografía, tablas e imágenes de cada corte temporal, para cuantificar las pérdidas y ganancias.

\begin{tabular}{lcccc}
\hline $\begin{array}{l}\text { NIVEL } \\
\text { SUPERIOR }\end{array}$ & $\begin{array}{c}\text { Proceso de } \\
\text { crecimiento } \\
\text { en La Plata }\end{array}$ & $\begin{array}{c}\text { Config. Urbana } \\
\text { Org. Social } \\
\text { Imagen Paisajística }\end{array}$ & - & Densificación \\
Expansión
\end{tabular}

Tabla 1. Esquema de niveles de aproximación y matriz de datos. Fuente: Elaboración propia en base a Murillo (2014)

Desde el nivel superior de análisis, se abordó la contextualización espacio-temporal del proceso de crecimiento y configuración de la ciudad; destacando los periodos y hechos que contribuyeron a la densificación habitacional del área central de la ciudad de La Plata. En el nivel central o anclaje se apuntó hacia la caracterización a partir de variables de análisis del paisaje urbano densificado, haciendo foco en el estudio de casos a partir de dos sectores de características opuestas a fin de comparar la diferencia en el proceso de verticalización. Y finalmente en el nivel inferior de análisis se buscó detallar la percepción de las transformaciones y la apropiación del paisaje urbano a partir de la valoración e identificación de los habitantes con el paisaje y de acción-transformación del espacio barrial.

En el nivel superior o contextual se abordó la descripción del proceso de configuración de la ciudad de La Plata a fin de comprender los procesos de configuración de la ciudad como contexto del proceso de densificación habitacional actual. Se apuntó a la reconstrucción histórica del proceso de crecimiento de la ciudad de La Plata estructurado en tres grandes etapas (Ravella, 2011): i) Periodo fundacional: 1980 a 1930, ii) Periodo de expansión/industrialización: 1930 a 1970, iii) Periodo neoliberal: 1970 a 2003. Este desarrollo histórico se completa con la 
incorporación de un último periodo, definido como periodo posneoliberal ${ }^{14}$, que abarca de 2004 a 2014, correspondiente al recorte temporal definido para la investigación.

El análisis apunta a reconocer los procesos de expansión y densificación en los cuatro momentos históricos definidos a partir de tres ejes de análisis. El eje organización social apunta al reconocimiento de los procesos demográficos y distribución territorial de la población, y el uso del suelo real y normativo en cada etapa. El eje de análisis configuración urbana apunta a detallar las características del espacio privado construido y el espacio público en la ciudad. El tercer eje detalla características paisajísticas, en el que se apunta a la descripción de los elementos y rasgos característicos del paisaje urbano y sus intervenciones, partiendo del diseño fundacional hasta sus posteriores transformaciones. Esta descripción permite determinar y caracterizar zonas homogéneas de crecimiento, destacando las zonas de mayor y menor densificación sobre las cuales profundizar el análisis en niveles sucesivos.

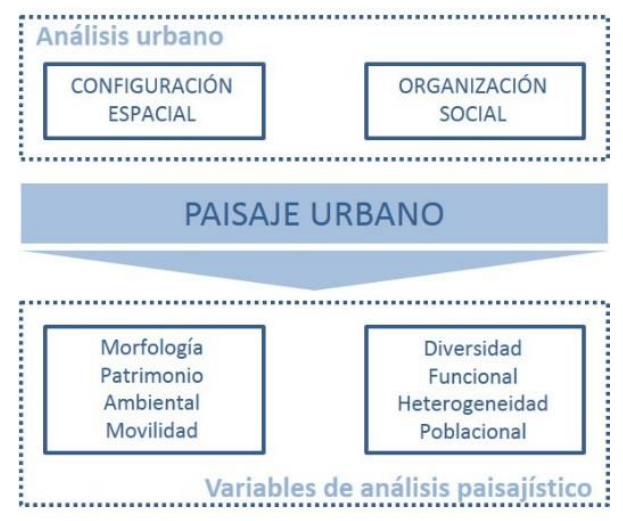

Cuadro 5. Esquema de elaboración de variables de la componente material. Fuente: Elaboración propia 2019

En el segundo nivel o nivel de anclaje se profundizó el análisis en las zonas densificadas seleccionadas a modo de zonas testigo. Para ello se analizan dos sectores de 56 hectáreas promedio situados en ubicaciones geográficas opuestas dentro del área central y con procesos de

\footnotetext{
${ }^{14}$ Fue una expresión utilizada por Emir Sader, Atilio Borón, Carlos Figueroa Ibarra, entre otros, para marcar una distancia con aquellos gobiernos neoliberales adscritos a la agenda del Consenso de Washington. Con el concepto de "posneoliberalismo" se trataba de ubicar en la nueva geopolítica a los regímenes latinoamericanos que surgían en disputa con EEUU y fuertemente críticos con el modelo neoliberal. Estos gobiernos cambiaron el sentido de las políticas públicas hacia políticas más inclusivas y con mayor sensibilidad social, preocupándose por la inversión social y la lucha contra la pobreza. En un inicio, algunos de estos gobiernos latinoamericanos incluso acudieron a la ideología del socialismo para legitimarse.
} 
densificación y verticalización edilicia diferentes a partir de un escenario base construido mediante fotos satelitales de Google Earth de 2004 comparado con el escenario del año 2014 realizado a partir del relevamiento de las áreas.

Para el análisis se toman las dimensiones "configuración urbana" y "organización social”, trabajadas en el nivel superior, con la reinterpretación de la propuesta para el análisis urbano de Kullock (1994), a partir del concepto de paisaje urbano desarrollado en el marco teórico. En este sentido, se define que para abordar con mayor detalle la dimensión "configuración urbana" se profundiza por separado en el espacio privado construido y en el espacio público. Focalizando, para el primero, en los aspectos morfológicos y patrimoniales, y para el segundo, en aspectos ambientales y de movilidad. La dimensión "organización social” apunta al reconocimiento del uso del espacio urbano y las características de la población urbana. Las variables para cada dimensión son las siguientes:

Configuración del Espacio privado construido: Incluye aspectos morfológicos (forma y apariencia) del espacio construido, incluyendo: i) Cantidad de edificios en altura por manzana, ii) Altura de edificios predominante por manzana, iii) superficie construida por manzana, iv) hitos urbanos, v) parque patrimonial existente.

Configuración del Espacio público: Da cuenta de la relación entre el espacio público de la ciudad, con su verde, vegetación, espacios abiertos y la movilidad, los automóviles circulando y estacionados. Incluye la cuantificación de componentes vegetales y forestales y la capacidad (en superficie o tamaño) del espacio público (calles, veredas, plazas) para absorber los "efectos derivados" del incremento de población. Las variables incluyen: i) Masa arbórea, mide la superficie cubierta por vegetación total en el sector, ii) Espacio verde libre por habitante iii) cantidad de autos, iv) capacidad de estacionamiento, que incluye la disponibilidad de estacionamientos privados y en el espacio público.

Organización social: define los niveles de actividades residenciales y no residenciales de las áreas analizadas, incluyendo las características de la población y hogares residentes y las cantidades y 
tipos de actividades no residenciales, incluyendo: i) actividad comercial (porcentaje de actividades comercial y de servicios en el sector), ii) actividad de recreación (porcentaje de actividades culturales y deportivas en el sector); iii) densidad de población, iv) tamaño de hogar ${ }^{15}$ predominante, mide el porcentaje de hogares pequeños (de hasta 2 integrantes), v) grupos etarios ${ }^{16}$ predominantes, mide el porcentaje de población joven (de 20 a 39), vi) nivel educativo ${ }^{17}$ predominante, mide el porcentaje de población con estudios de nivel universitario.

\begin{tabular}{|c|c|c|c|}
\hline DIMENSION & ASPECTO & VARIABLE & UNIDAD \\
\hline \multirow{5}{*}{$\begin{array}{l}\text { CONFIGURACION } \\
\text { ESPACIO } \\
\text { PRIVADO } \\
\text { CONSTRUIDO }\end{array}$} & \multirow{3}{*}{ Morfología } & $\begin{array}{l}\text { Cantidad de edificios en } \\
\text { altura por manzana }\end{array}$ & unidad \\
\hline & & $\begin{array}{l}\text { Alturas de edificios } \\
\text { predominante por } \\
\text { manzana }\end{array}$ & pisos \\
\hline & & $\begin{array}{l}\text { Superficie construida por } \\
\text { hectárea }\end{array}$ & $\mathrm{m} 2 / \mathrm{ha}$ \\
\hline & \multirow[b]{2}{*}{ Patrimonio } & Hitos urbanos & unidad \\
\hline & & $\begin{array}{l}\text { Parque patrimonial } \\
\text { existente }\end{array}$ & unidad \\
\hline \multirow{4}{*}{$\begin{array}{l}\text { CONFIGURACION } \\
\text { ESPACIO } \\
\text { PUBLICO }\end{array}$} & \multirow{2}{*}{ Ambiental } & Masa arbórea & $\mathrm{m} 2$ \\
\hline & & Esp. Verde libre / hab. & m2/hab \\
\hline & \multirow[b]{2}{*}{ Movilidad } & Cantidad de autos & unidad \\
\hline & & $\begin{array}{l}\text { Capacidad de } \\
\text { estacionamiento }\end{array}$ & autos/est. \\
\hline \multirow{6}{*}{$\begin{array}{l}\text { ORGANIZACIÓN } \\
\text { SOCIAL }\end{array}$} & \multirow{2}{*}{$\begin{array}{l}\text { diversidad } \\
\text { funcional }\end{array}$} & Actividad comercial & porcentaje \\
\hline & & Actividad recreativa & porcentaje \\
\hline & \multirow{4}{*}{$\begin{array}{l}\text { heterogeneidad } \\
\text { poblacional }\end{array}$} & Densidad de población & hab/ha \\
\hline & & $\begin{array}{l}\text { tamaño de hogar } \\
\text { predominante (1 y } 2 \\
\text { personas) }\end{array}$ & porcentaje \\
\hline & & $\begin{array}{l}\text { grupo etario } \\
\text { predominante (20-39 } \\
\text { años) }\end{array}$ & porcentaje \\
\hline & & $\begin{array}{l}\text { nivel educativo } \\
\text { predominante } \\
\text { (universitarios) }\end{array}$ & porcentaje \\
\hline
\end{tabular}

Estas variables y dimensiones se reconstruyen para la comparación de escenarios 'base' año 2004 y año 2014, se analizan y comparan las pérdidas y ganancias para la detección de las variables que presentan el mayor cambio o impacto en el sector. Dichos resultados fueron ponderados con un criterio de impacto bajo-medio-alto, con un código de colores tipo semáforo (verde-amarillo-

\footnotetext{
${ }^{15}$ Para este análisis se utilizó una segmentación de hogares por tamaño: hogar pequeño hasta 2 integrantes, hogar medio hasta 4 integrantes, hogar grande 5 integrantes o más.

${ }^{16}$ Para este análisis se utilizó una segmentación de población en grupos etarios: niños de 0 a 19 , jóvenes de 20 a 39, adultos de 40 a 64, adultos mayores de más de 65 años.

${ }^{17}$ Para este análisis se utilizó una segmentación de población por niveles educativos: Nivel primario, nivel secundario, nivel terciario, nivel universitario.
} 
rojo). Dichos resultados serán insumo para la construcción del instrumento de indagación en el siguiente nivel de análisis.

En el nivel inferior o nivel de detalle se analiza la percepción de los habitantes de los sectores en transformación, indagando en cómo se asimilan dichas transformaciones. Para el análisis de la percepción de los habitantes se construyó un método a partir del concepto de "apropiación del espacio".

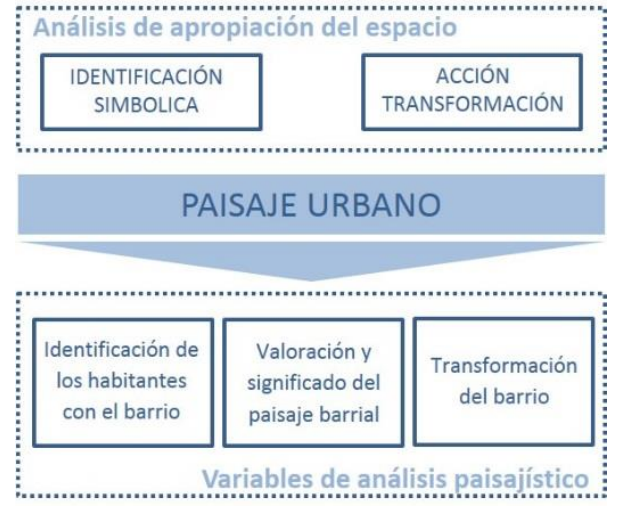

Cuadro 6. Esquema de elaboración de variables de la componente simbólica. Fuente: Elaboración propia 2019

Para ello se retomaron antecedentes desplegados en investigaciones anteriores (López, Freaza, \& al, 2014), que parten del estudio desarrollado por Vidal- Pol (2005) en el que se trabaja con dos mecanismos principales para el estudio del proceso de apropiación del espacio: la accióntransformación y la identificación simbólica. Este método tiene tres componentes de la dimensión de la acción: acciones cotidianas en el lugar; acciones orientadas hacia el lugar y acciones en torno a los proyectos de futuro del lugar. A su vez la dimensión de la identificación se compone de tres procesos: identificar el entorno, ser identificado por el entorno e identificarse con el entorno. A partir de dichos mecanismos se desarrollaron tres dimensiones de abordaje con sus respectivas variables: identificación de los habitantes con el barrio, valoración y significado del paisaje barrial, transformación del barrio; las que, estructuraron la construcción de la herramienta metodológica.

También se tomaron como antecedentes los estudios de Corraliza (2009), donde se analiza la valoración de los ambientes urbanos y se desarrolla un instrumento metodológico para la 
obtención de datos. Se toma del trabajo, el concepto "dimensiones afectivas del ambiente", para referir a la carga afectiva y al valor indicativo de la experiencia emocional de las personas en un determinado lugar. También se toma la aplicación técnica de evaluación de los ambientes, utilizando la representación semántica con pares opuestos de adjetivos, los cuales se organizan en cuatro grupos, estructurados por factores de incidencia: Factor de Agrado, Factor de Activación, Factor de Impacto, Factor de Control.

- Factor I: Agrado: Se interpreta como una dimensión de atracción del objeto hacia el sujeto evaluador, donde se valora el atractivo o agrado que produce en los sujetos un determinado lugar. "agradable/desagradable".

- Factor II: Activación: Está relacionado con la dimensión de incitación/estimulación, esta dimensión refleja el grado de "viveza" de un lugar, en función de la respuesta emocional de las personas. "tranquilo/intranquilo".

- Factor III: Impacto: En esta dimensión se considera el carácter llamativo o no de un lugar, y el carácter de señal significativa que adquiere. "significativo/insignificante".

- Factor IV: Control: En este factor aparece la dimensión de control y organización del ambiente. "tranquilo/intranquilo"; "cuidado/descuidado".

La técnica que se utilizó en un cuestionario, consistió en combinar la modalidad personal y online, estructurada en tres bloques temáticos:

Identificación de los habitantes con el barrio: se busca el nivel de reconocimiento del área donde reside, como una unidad barrial, social o paisajística, buscando indicios de identidad colectiva y elementos característicos vinculados a ella.

Valoración y significado del paisaje barrial: se indaga en la preferencia y valoración de los habitantes sobre imágenes de distintos sectores del barrio. 
Transformación del barrio: se indaga en la percepción de los habitantes residentes, acerca de los cambios morfológicos y de las variaciones consecuentes en las dinámicas urbanas, en el reconocimiento de los espacios colectivos, en el uso de dichos espacios y en la participación en actividades vecinales.

\begin{tabular}{|c|c|}
\hline DIMENSION & VARIABLE \\
\hline \multirow{3}{*}{$\begin{array}{l}\text { IDENTIFICACIÓN DE } \\
\text { LOS HABITANTES CON } \\
\text { EL BARRIO }\end{array}$} & Reconocimiento de identidad o nombre de su barrio \\
\hline & Reconocimiento de los límites del barrio \\
\hline & Caracterización del paisaje barrial \\
\hline \multirow{3}{*}{$\begin{array}{l}\text { VALORACIÓN Y } \\
\text { SIGNIFICADO DEL } \\
\text { PAISAJE BARRIAL }\end{array}$} & Estado del paisaje \\
\hline & Valoración del paisaje del espacio privado densificado \\
\hline & Valoración del paisaje del espacio público \\
\hline \multirow{4}{*}{$\begin{array}{l}\text { TRANSFORMACIÓN } \\
\text { DEL BARRIO }\end{array}$} & Percepción de la transformación del paisaje \\
\hline & Acciones orientadas al barrio \\
\hline & Apropiación de espacios colectivos \\
\hline & Actividades colectivas vecinales \\
\hline
\end{tabular}

Tabla 3. Dimensiones y variables de la componente simbólica. Fuente: Elaboración propia 2019

El análisis de las entrevistas permitió arribar a una síntesis de las transformaciones percibidas por los habitantes de cada zona. En relación a la dimensión apreciación e identificación con el barrio, se reconstruyó el imaginario barrial sobre los límites físicos del mismo y la identidad. Relacionando dicho imaginario con los datos particulares de los entrevistados como el tiempo de residencia y la edad.

La dimensión de la acción y transformación del barrio, contribuyó a recategorizar las variables construidas para el análisis del proceso de densificación habitacional a partir de la percepción de las transformaciones. Asimismo, permitió contrastar con el análisis en el nivel de anclaje y sopesar el impacto relativo de cada variable, a efectos de reconocer el grado de interacción de los habitantes con el lugar, construyendo un índice de apropiación del espacio.

En la dimensión de valoración y significado, se buscó reconocer el grado de apreciación de “escenas paisajísticas" diferentes, a fin de dimensionar el factor de incidencia de los elementos y/o características urbanas a partir de 5 factores: "agradable/desagradable"; "tranquilo/ intranquilo"; "significativo/ insignificante"; "tranquilo/ intranquilo"; "cuidado/descuidado". 
La investigación buscó comprender si efectivamente se produjo un quiebre de los procesos de apropiación de la población histórica con su entorno, a partir de cambios materiales y simbólicos del paisaje urbano producidos por la verticalización edilicia en el área central. Como estrategia, se construyó una matriz de análisis con las principales percepciones relatadas por los entrevistados en cada zona, y que puedan resultar (resulten) recurrentes y relevantes en el análisis de cada sector.

En síntesis, a partir de los criterios metodológicos anteriormente presentados, como se pueden observar en el cuadro 7, se diseñó el camino de la investigación para dar respuesta a los objetivos e hipótesis planteados en la Introducción de la Tesis.

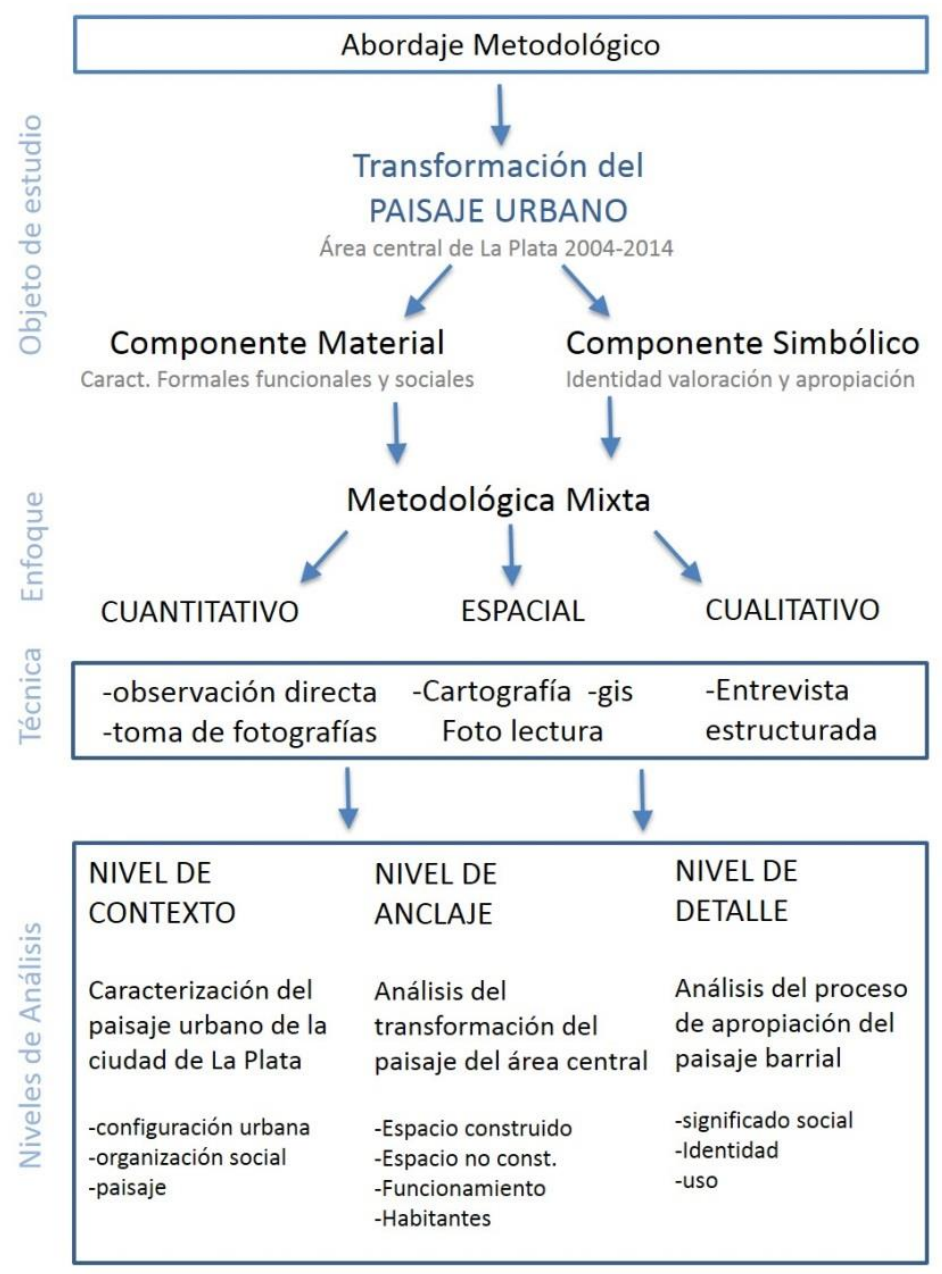

Contrastación de hipótesis

Cuadro 7. Síntesis de la propuesta metodológica. Fuente: Elaboración propia 2019 
CAPITULO 4. La construcción del paisaje platense 


\section{Dos direcciones en la configuración del paisaje platense}

El presente capítulo aborda la descripción del proceso de crecimiento de la ciudad de La Plata a fin de reconstruir el proceso de configuración y consolidación del paisaje de la ciudad. Este apartado corresponde al nivel superior o contextual de análisis como se ha detallado en el apartado metodológico (capítulo 3), y profundiza en tres dimensiones de abordaje: Configuración urbana, organización social y composición del paisaje urbano. Este capítulo se estructura a partir de dos procesos principales que orientan el crecimiento de la ciudad, i) el proceso de expansión hacia la periferia y ii) el proceso de densificación en el área central de la ciudad.

La ciudad de La Plata es la capital de la provincia de Buenos Aires, se ubica en el Noreste de la provincia, a 60 kilómetros de la Capital Nacional, formando parte de la región metropolitana. Esta región representa el 2\% del territorio argentino; sin embargo, concentra el 33\% de la población del país.
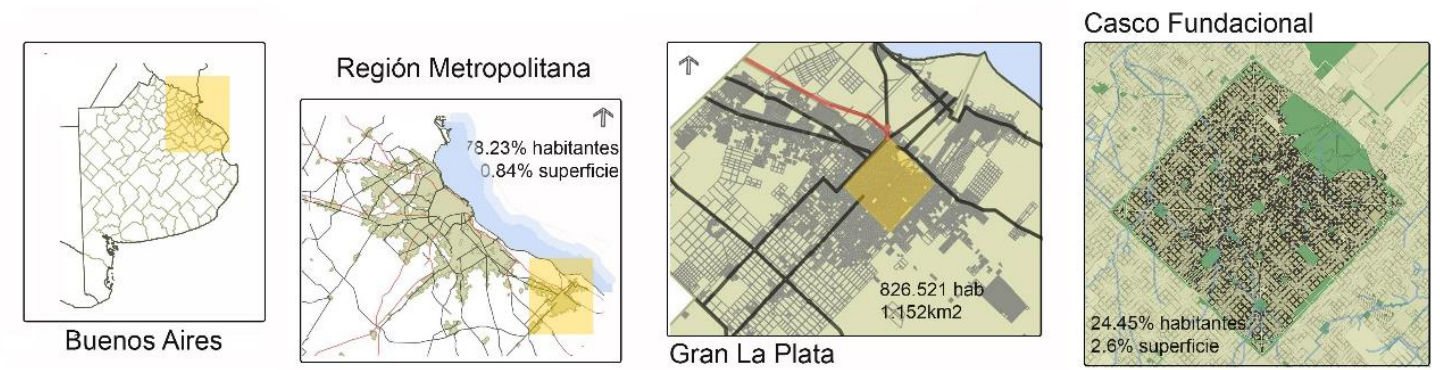

Imagen 2. Ubicación geográfica de La Plata y datos poblacionales Año 2014. Fuente: Elaboración propia en base a datos censo INDEC (2010)

Asimismo, La Plata se constituye en la ciudad cabecera la región del Gran La Plata, la que conforma junto con los municipios de Berisso y Ensenada. Cuenta con una población de 654.324 habitantes (censo 2010) y con una superficie de 942,23 km2. La ciudad tiene un perfil 
administrativo y universitario complementado con la actividad industrial y es una de las zonas de producción frutihortícola más importante del país.

La ciudad de La Plata es una de las pocas ciudades del país de fundación planificada ${ }^{18}$, lo que le ha otorgado una característica paisajística muy particular. El diseño urbano proyectado tenía lineamientos para el crecimiento de la trama urbana fundacional, sin embargo, a lo largo de los años la ciudad fue desarrollándose condicionada por procesos económicos políticos y sociales, que tensionaron la configuración en dos direcciones, la expansión horizontal y la densificación vertical.

\section{Expansión y horizontalidad}

El proceso de configuración urbana de la ciudad de La Plata se estructura en tres grandes cortes históricos (Ravella, 2011): i) periodo fundacional: 1980 a 1930, ii) Periodo de expansión/ industrialización: 1930 a 1970, iii) Periodo neoliberal: 1970 a 2003. Estos cortes históricos están dados principalmente por situaciones y características de la economía que incidieron directamente en la configuración urbana (ver Imagen 3).

El primer periodo (1882-1930) o periodo fundacional se inicia con la fundación de la ciudad de La Plata y se remonta a fines del siglo XIX, momento de definición del modelo de desarrollo y organización del Estado Argentino. En 1881 se define la federalización la ciudad de Buenos Aires y la consecuente separación de la provincia de Buenos Aires. Para lo cual se requería de una nueva ciudad con el fin de albergar la nueva capital de la Provincia de Buenos Aires.

\footnotetext{
${ }^{18}$ La ciudad de La Plata (1882) es ejemplo de ciudades de fundación planificada junto a otras en el país como Chivilcoy, Buenos Aires (1854); Campana, Buenos Aires (1875); Resistencia, Chaco (1878); Formosa, Formosa (1879).
} 
La nueva ciudad debía ser un verdadero centro provincial, para ello se estableció una serie de condiciones de organización y configuración que debía cumplimentar la nueva ciudad, para posicionarla como una ciudad de jerarquía. Por un lado, una buena accesibilidad y conectividad, y por el otro, una imagen de ciudad moderna.

Durante el periodo posterior a la fundación se afirma la organización funcional de la ciudad, estableciendo un perfil como sede administrativa de jerarquía provincial, con actividades productivas ligadas al puerto, los frigoríficos, la destilería YPF, actividades del conocimiento a través del rol de la Universidad creada en 1887, y las instalaciones relacionadas (museo de ciencias naturales, zoológico y observatorio astronómico), que conforman un polo educativo.

Se incorporan las innovaciones tecnológicas a la estructura urbana tales como el ferrocarril, el tranvía eléctrico, la iluminación eléctrica, telegrafía, que permitieron lograr un importante grado de desarrollo. Coincidentemente con el periodo de expansión de los ferrocarriles argentinos, el tendido de redes permitió conectar a la ciudad de La Plata y su puerto con las redes que cubrían el Oeste y el Sur del territorio provincial y con la ciudad de Buenos Aires, a partir de la cual se conectaba con el resto del país (Ravella, 2011).
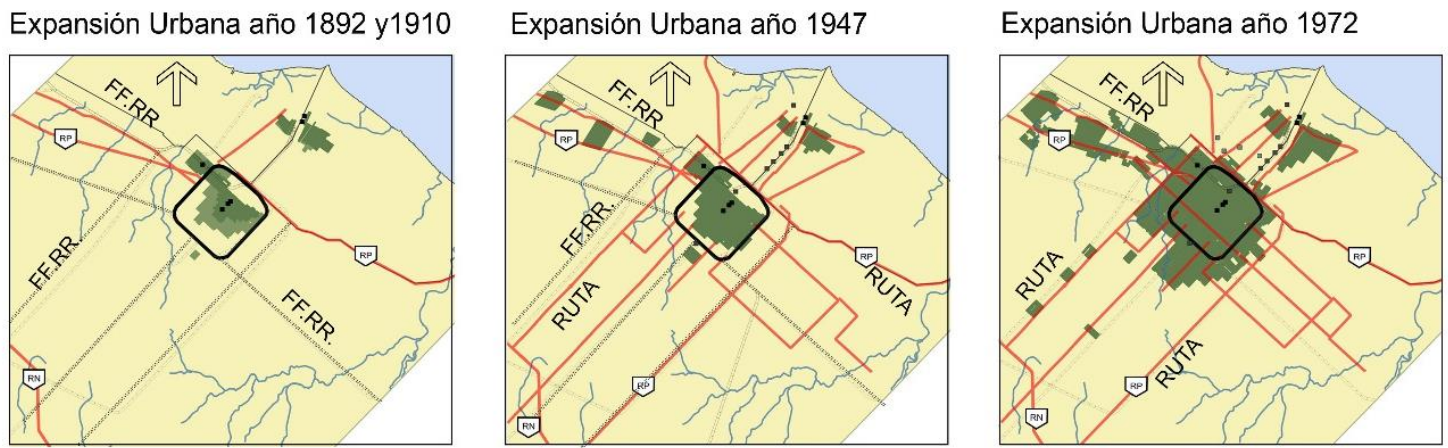

\section{Imagen 3. Estructura urbana, usos y distribución de la población de los periodos analizados. Fuente: Elaboración propia en base a Frediani (2010)}

El crecimiento poblacional del periodo se basa en el aporte migratorio, que se radicó en áreas periféricas, principalmente en los poblados de Berisso y Ensenada, debido a la especulación sobre las tierras urbanas dotadas de servicios en el área central. Fenómeno especulativo que como explica Frediani (2010) es consecuencia de la concentración de actividades comerciales y 
administrativas, que han generado procesos de concentración-expulsión, configurando una estructura urbana dispersa, desarticulada, y socialmente fragmentada. Dicho fenómeno se presenta tempranamente en el caso de La Plata por ser una ciudad donde la infraestructura antecedió al asentamiento de la población.

La configuración de la ciudad debía tener características de modernidad, tiene una impronta ambiental muy fuerte desde su creación, tomando ideas del higienismo ${ }^{19}$ europeo, y de experiencias locales como la ciudad de Campana. También se incluyen consideraciones de comunicación terrestre y fluvial con el interior del país y el exterior, se tiene en cuenta la infraestructura necesaria y el abastecimiento de alimentos, a partir de un cinturón de chacras para producción frutihortícola.

Para este encargo se designó como director ejecutivo de las obras a Pedro Benoit, a quien se le adjudica la autoría del plano fundacional y una serie de edificios emblemáticos. El diseño de la traza se desarrolló sin conocer la ubicación específica, lo que explica que la trama urbana se implante desconociendo las características de la topografía. El plano fundacional adoptó la forma del cuadrado perfecto de 5.196 metros de lado, planificada para una población de 150.000 a 250.000 habitantes, y una densidad máxima de 55 a 75 habitantes por hectárea.

En relación al paisaje, se buscaba una imagen representativa del poder de una ciudad capital con estética europea. Desde el diseño del trazado se incorporan cuatro sistemas de elementos materiales: el sistema de calles, avenidas y diagonales; el sistema de plazas y espacios verdes; el sistema de amanzanamiento y el sistema de distribución de edificios públicos. Y elementos simbólicos, a partir de la inclusión de elementos arquitectónicos y paisajísticos, que aportan a una imagen de ciudad capital con proyección internacional, sobre un trazado homogéneo con edificaciones de baja altura y sencillas.

\footnotetext{
${ }^{19}$ El higienismo (siglo XIX) es una corriente que surge a comienzos del siglo XIX por las epidemias provocadas por las condiciones de vida, esto lleva a mejorar las condiciones de salubridad en el ambiente de la ciudad mediante la instalación de agua corriente, cloacas, iluminación en las calles.
} 
La traza está delimitada por una avenida periférica, enmarcando la superficie urbanizada y delimitando el área urbana, la cual es atravesada por un eje perpendicular al río cargado de simbología. Dicho eje se proyecta más allá de la superficie urbana como una línea que conecta el puerto, como apertura al mundo, y la pampa profunda, en alusión a la producción de granos y ganado, representa la imagen de centro productivo que pretendía competir con el puerto de Buenos Aires. Sobre el eje de influencia barroca, se disponen los edificios sede del poder espiritual -la Catedral-, el poder civil -la municipalidad- en un nivel jerárquico en el centro de la ciudad, así como también los poderes ejecutivo y legislativo de nivel provincial -la legislatura y la Casa de Gobierno- en igualdad de condiciones. Esta disposición en el centro de la traza, a igual distancia de todos los ciudadanos, sugiere la accesibilidad de la población a sus gobernantes.
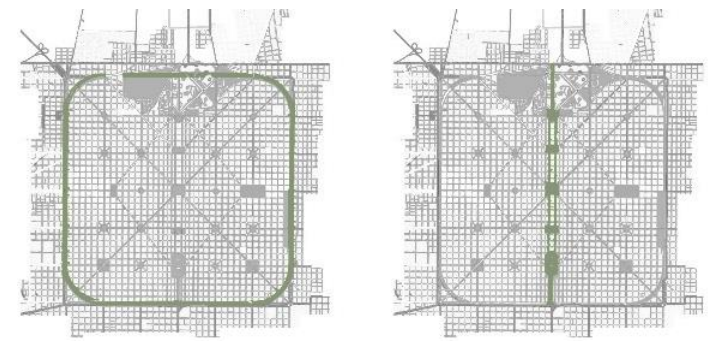

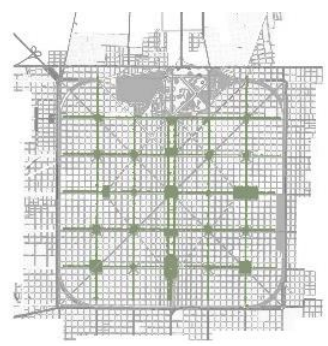

Imagen 4. Elementos de la estructura urbana según plano fundacional. Fuente: Elaboración propia en base a Garnier (1994)

El sistema vial está organizado de manera jerárquica (ver

Imagen 4), con cuatro niveles de funcionamiento. El primer nivel está dado por la avenida periférica, que tiene por objetivo la distribución de los flujos circulatorios hacia las avenidas internas del cuadrado. El segundo nivel lo conforman las once avenidas dispuestas en grilla cada seis cuadras, que delimitan treinta y seis secciones, y también se prolonga por fuera del perímetro marcando la zona de cultivo que luego se transformó en periferia. El tercer nivel lo dan las diagonales que surcan toda la traza remarcando centralidades, mejorando la circulación y el acceso al centro. El cuarto nivel está conformado por las calles de la cuadricula colonial tradicional. Este sistema se caracteriza por elementos paisajísticos para diferenciar las calles, el solado para las calles de la cuadrícula es diferente al de las avenidas en la forma y el color de las 
bandas que marcan la línea municipal. Además, hay una caracterización de la vegetación plantada: plátanos, tilos, naranjos y jacarandás dan una coloración y aroma particular a cada una.

La vegetación es un elemento que se utilizó para dotar de carácter a cada sector del trazado de la ciudad. El sistema de espacios verdes también tiene una organización jerarquizada, y constituye parte determinante de la composición de la ciudad. La distribución de espacios verdes está en relación al sistema vial, se dispuso una plaza en las intersecciones de avenidas y diagonales. Los tamaños de las plazas refieren al carácter de las vías que confluyen, en el caso de que confluyan diagonales el tamaño de la plaza es mayor. La distribución que se logra con la combinación de las avenidas y las plazas conforman sectores que tienen como verdaderos centros de barrios a las plazas que en algunos casos tienen funciones cívicas y en otros están destinadas albergar ferias cotidianas.
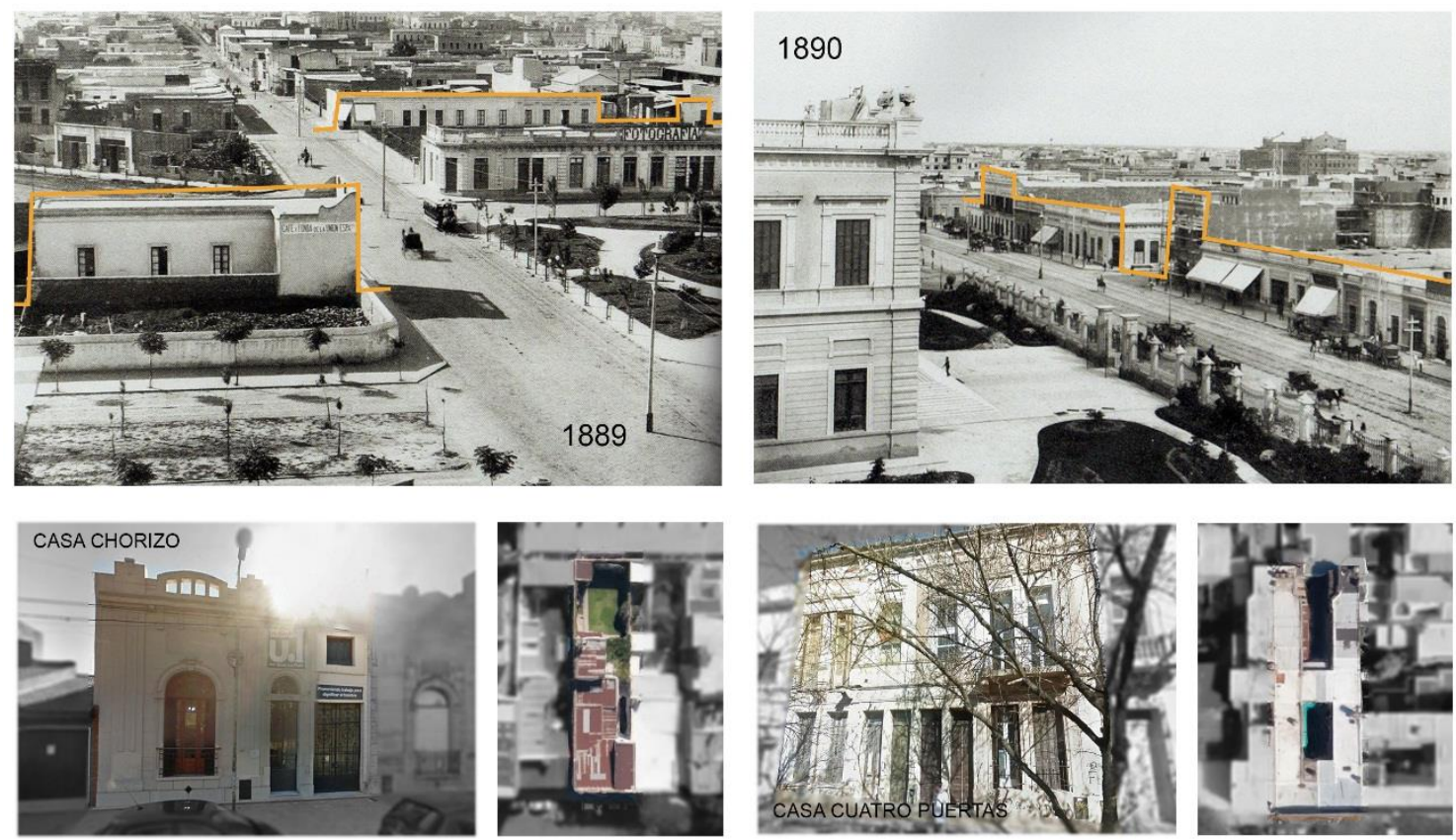

Imagen 5. Paisaje urbano y tipologías de vivienda, etapa fundacional 1882-1930. Fuente: Elaboración propia en base a relevamiento Google Earth y página web: Fotos históricas de La Plata.

El sistema de amanzanamiento en la ciudad de La Plata presenta características particulares. En principio, las manzanas (120m de lado) son de mayor tamaño que la tradicional manzana de las Leyes de Indias, éstas decrecen en ancho a medida que se acercan al eje monumental, con la intención de remarcar su importancia. A su vez, la superposición de las calles diagonales 
fracciona estas manzanas generando parcelamientos irregulares, resultando en tipologías arquitectónicas muy particulares. El tejido de la ciudad también estuvo previsto, se proyectó un tejido compacto continuo y cerrado, los corazones de manzana cumplían una función de pulmón verde, las construcciones estaban alineadas sobre el eje municipal y las alturas no podían sobrepasar a los edificios emblemáticos. En la Imagen 5 se observa el perfil urbano que se consolida con tipologías de vivienda unifamiliar y multifamiliar de uno y dos niveles, y mucha ocupación de la superficie de la parcela.

De esta manera, se construye un paisaje altamente planificado, con muchas referencias simbólicas y funcionales, con referencias urbanas establecidas y el espacio público como protagonista. Si bien existen normas relacionadas a morfología urbana desde el origen de la ciudad, durante este periodo no se elaboran códigos de uso del suelo que controlen y regulen el crecimiento de la ciudad. Sin embargo, hasta la finalización de este periodo, el crecimiento urbano no había quebrado el equilibrio de los ideales fundacionales.

El segundo periodo (1930 a 1970) está signado por un cambio de modelo a nivel nacional que impacta a nivel local en términos de organización social y configuración urbana. Uno de los cambios más importantes es el cambio del modelo económico productivo que pasó del modelo agroexportador que promocionaba la exportación de materias primas, al modelo de sustitución de importaciones que impulsó la industria de bienes de consumo en el país. Las principales ramas que se instalaron en la cuidad estaban relacionadas con la industria textil, la metalmecánica, los productos para el campo, y los servicios ligados al ferrocarril, debilitando el perfil portuario de exportación de carnes y granos.

El paisaje de la ciudad se transformó drásticamente en términos materiales y simbólicos durante este periodo. La sanción en 1932 de la Ordenanza N9/32 aleja el modelo de ciudad del concepto fundacional, ya que permite la implantación de edificios en altura en cualquier punto de la ciudad (ver Imagen 6). Otro cambio de gran impacto en el paisaje de la ciudad es la Ley de propiedad 
horizontal de 1948, que transforma la forma de comercialización del suelo urbano, lo que implicó la posibilidad de subdividir parcelas tanto en horizontal como en vertical.

Dicho cambio en la legislación comienza la transformación del perfil urbano, animando la renovación edilicia con procesos de especulación que habían aparecido en periodos anteriores. Atendiendo a la pérdida de símbolos del paisaje fundacional, en 1949 se sanciona el Código de Edificación que introduce el concepto de Preservación, intentando recuperar el valor del trazado urbano fundacional y estableciendo su conservación.
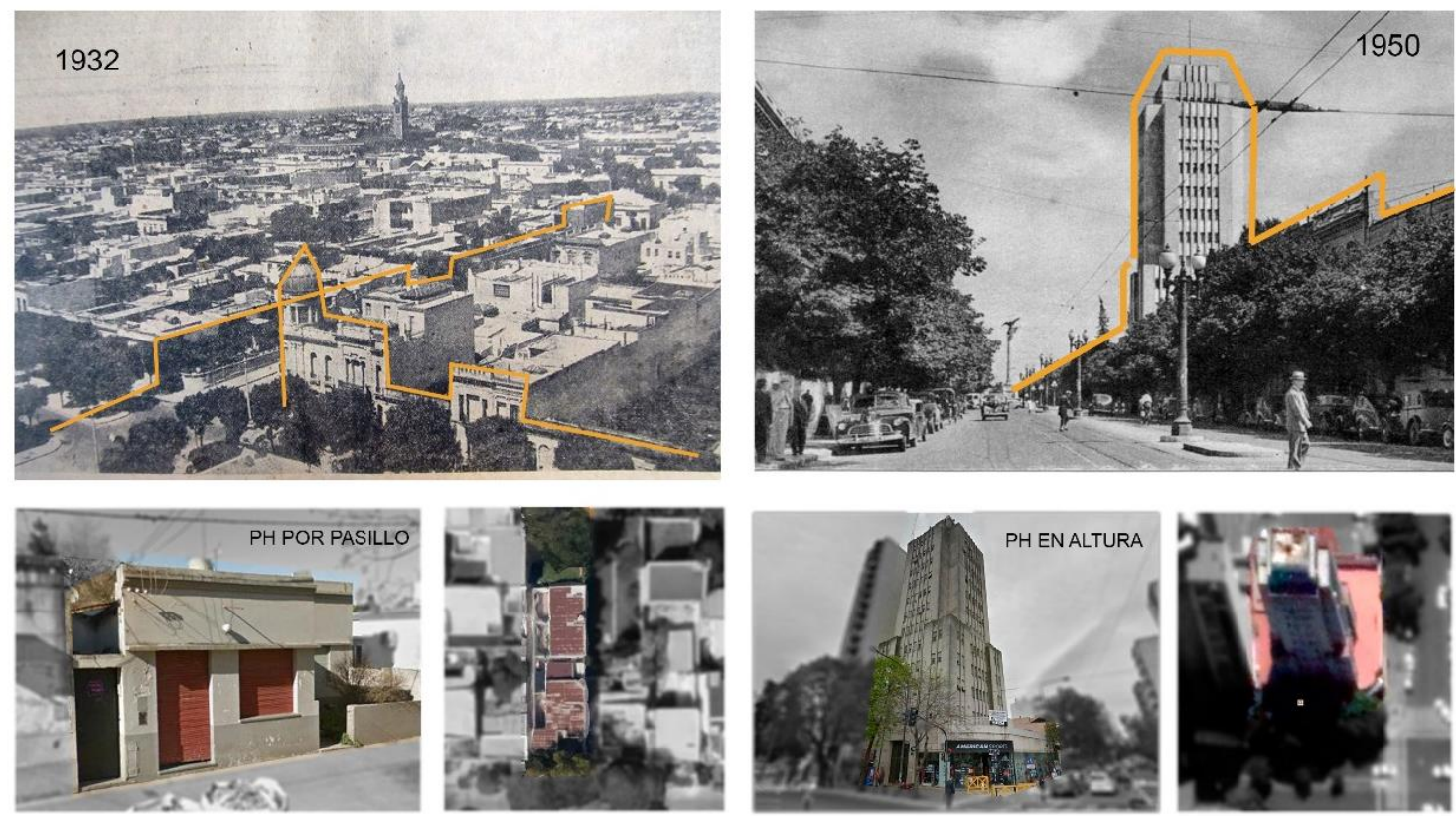

Imagen 6. Paisaje urbano y tipologías de vivienda, periodo 1930 - 1970. Fuente: Elaboración propia en base a relevamiento Google Earth y página web: Fotos históricas de La Plata.

Hacia 1960 se invierten las tendencias de crecimiento, a raíz de un auge constructivo e inmobiliario, que provoca la densificación habitacional del área central. Las tipologías características de esta época son, por un lado, la vivienda multifamiliar con departamentos en planta baja alineados por pasillos, derivada de la vivienda racionalista y, por otro lado, el edificio en altura sucesor de la casa de rentas (Frediani, 2010). Ambas tipologías incrementaron la densidad pero con resultados muy distintos en el paisaje urbano, las últimas iniciaron el proceso de verticalización en el área central, sin embargo, de manera muy aislada tanto que se 
constituyeron en referencias simbólicas del paisaje como lo es el caso del edificio de calle 7 y 45 estilo racionalista (ver Imagen 6).

El cambio del paradigma en movilidad dado por el auge del automóvil tuvo gran impacto en este periodo. Hasta 1960 la superficie urbanizada se focalizaba en torno a las estaciones ferroviarias de las localidades periféricas, a partir de las cuales se expande alcanzando nuevas zonas gracias al uso del automóvil y la red vial expandida. La infraestructura vial se expande y el transporte colectivo migra del tranvía hacia el transporte colectivo automotor en 1966, incidiendo dicho cambio en la distribución poblacional. Durante este periodo la ciudad continuó extendiéndose hacia la periferia, especialmente sobre el eje Noroeste, por los Caminos Centenario y Gral. Belgrano, lo que implicó que el Eje Monumental pierda referencia frente a los ejes de movilidad de las avenidas 7 y 13, como accesos principales a la ciudad.

El tercer periodo (1970 a 2003) es un momento de consolidación de un modelo. Se caracteriza por un cambio productivo dado por las nuevas tecnologías de comunicación e información que inciden en una reestructuración de la economía pasando del modelo industrial a la globalización de los mercados. En el caso de la Argentina esto representó la implantación de políticas neoliberales iniciadas en la década de 1970 con la dictadura militar y consolidada en la década de 1990. Políticas aplicadas a partir de privatizaciones de empresas públicas, desregularizaciones de los mercados, flexibilización laboral, desmantelamiento de los servicios públicos y la restricción del gasto público. En la región, esta política se plasmó en la privatización de YPF y la aparición de los hipermercados.

Respecto a la configuración de la ciudad, dicho contexto profundizó el cambio en el sistema de movilidad, mediante el desmantelamiento de la red ferroviaria y privatización (1993) (Ravella, 2011), que implicó para la región de La Plata el cierre de casi todas las líneas ferroviarias, manteniendo solo el servicio de pasajeros hacia ciudad de Buenos Aires. En paralelo, se promocionó al sector automotor en detrimento del ferrocarril fomentando un modelo individual 
de movilidad junto con el incremento de la infraestructura vial pavimentada. Este modelo profundizó la extensión de la periferia sobre los ejes viales.

Sobre a la distribución de la población, el proceso de densificación en el área central iniciado en la etapa anterior comenzó a revertirse, se produjo un crecimiento poblacional de las áreas periféricas y un decrecimiento poblacional del casco urbano que se mantiene hasta finales del siglo. En 1977 se sanciona el Decreto Ley provincial de Ordenamiento Territorial y Uso Del Suelo $\mathrm{n}^{\mathrm{o}} 8912^{20}$, este que establece estándares mínimos de uso, ocupación, subdivisión y equipamiento del suelo, lo que permitió principalmente organizar y orientar los procesos de expansión urbana de las ciudades de la provincia. La implementación de esta ley se acompañó por un nuevo modelo de desarrollo urbano, propiciado por el libre mercado de la tierra, que incorporaron distintas modalidades de urbanizaciones cerradas avanzando sobre el territorio rural. De esta manera la ciudad de La Plata experimenta en dicho periodo un fenómeno de migración del centro hacia las periferias, un fenómeno compartido con otras ciudades de la región (Aón \& al, 2008).

Hacia el final del periodo el área central comienza a insinuar cambios con la aparición de edificios en altura (ver Imagen 7). "Paralelamente a los procesos periféricos, las áreas centrales evidencian una tendencia de densificación habitacional siguiendo las pautas del mercado inmobiliario y de los sectores privados, en el marco de una normativa orientada a la densificación central y con una baja intervención del Estado en materia de planificación, de renovación y adaptación de los servicios y equipamientos urbanos a los nuevos niveles de población" (Aón, 2012).

${ }^{20}$ El Decreto Ley provincial de Ordenamiento Territorial y Uso Del Suelo nº8912 establece un marco mínimo de referencia de ocupación del suelo con estándares mínimos de uso, ocupación, subdivisión y equipamiento del suelo. El mismo tiene vigencia hasta la actualidad y ha permitido que muchos municipios de la provincia desarrollen un plan urbano asistido por la provincia. 

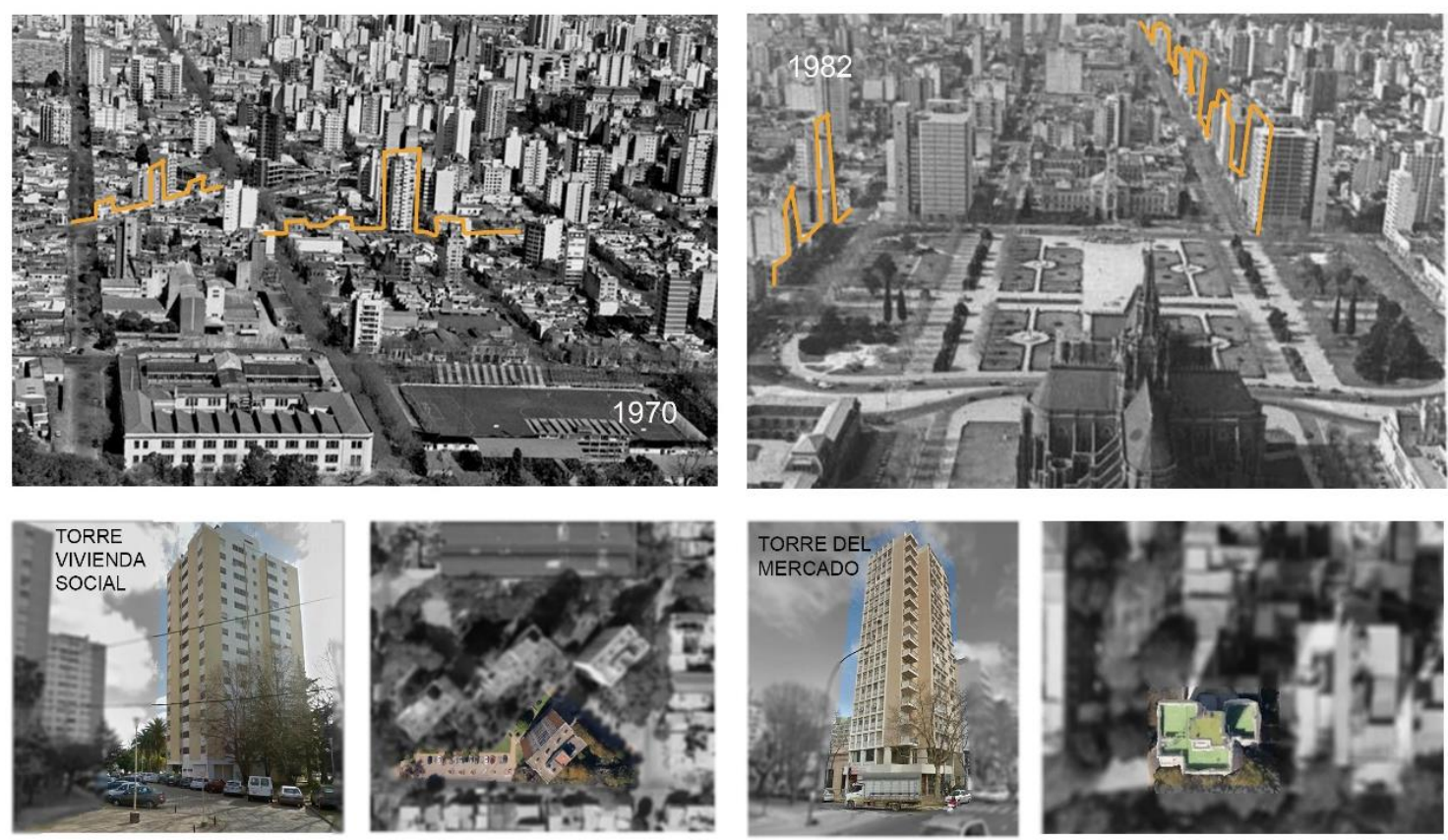

Imagen 8. Paisaje urbano y tipologías de vivienda, periodo 1970-2003. Fuente: Elaboración propia en base a relevamiento Google Earth y página web: Fotos históricas de La Plata.

Respecto al paisaje las transformaciones materiales comienzan a incidir en las componentes simbólicas, los procesos de densificación se orientan a la verticalización con edificios en altura que superan la referencia histórica definida por la altura de las torres de la catedral, acentuando la transformación del perfil original, avalado por la normativa de uso del suelo vigente desde 1978. Incluso algunas intervenciones urbanas de origen estatal no solo construyen con alturas máximas, sino que intervienen transformando la relación de llenos y vacíos del tejido urbano tradicional. Esto se puede ver en los casos de vivienda social construidos dentro del casco fundacional, donde se invierte la relación de lleno y vacío, otorgando gran cantidad de espacio al uso recreativo y al automóvil. Sin embargo, hasta el fin de siglo XX el perfil urbano de la ciudad era principalmente bajo, de uno y dos niveles de altura, los edificios en altura se concentran en el microcentro comercial de la ciudad. 


\section{Densificación y verticalidad}

A partir del cambio de siglo convergen una serie de factores que permiten definir un cambio de periodo. El cambio de siglo comienza con una fuerte crisis del modelo implementado en el periodo anterior, la crisis financiera nacional de 2001. A partir del año 2003 se implementaron un conjunto de políticas que implicaron un cambio en el modelo de desarrollo, un viraje importante hacia un modelo productivo (Seijo, 2011). Como lo define el economista Katz (2012) este periodo se puede caracterizar "por una política económica neo-desarrollista, priorizando el consumo y favoreciendo a los sectores agroindustriales en desmedro de los financistas". Este modelo generó un excedente de capitales, principalmente de los sectores agrarios y sectores medios y altos, que se volcaron hacia el mercado de la construcción.

La ciudad mantiene el crecimiento extensivo consolidando el crecimiento en las periferias de las zonas este y suroeste del partido. En esta etapa la actividad de la construcción se ve fortalecida por el acceso al crédito hipotecario que permite el acceso a la vivienda propia a la clase media. Sin embargo, al no estar regulado, el precio del suelo se incrementa rápidamente, lo que genera que las nuevas construcciones se ubiquen en los límites de la zona urbana, extendiendo más aún la mancha urbana sobre zonas sin infraestructura.

Al mismo tiempo, en el área central de la ciudad se incrementa la construcción de edificios de viviendas en altura, impulsado por capitales inversionistas. El incremento de las inversiones inmobiliarias durante esta década es utilizado como mecanismo de ahorro de capital, en especial, el fenómeno conocido como Bonos de Ladrillo ${ }^{21}$. Principalmente se realizan edificios sobre los

\footnotetext{
${ }^{21}$ Sin crédito, el inversor financió al emprendedor. Pero sin instrumentos de mediación, en lugar de suplir al financista este inversor reemplazó a la demanda real. La cuestión fue entonces (re)producir y despachar un ticket estandarizado de inversión por " $\mathrm{x}$ " dólares, traducidos a m2: las commodities que reemplazarían a los papeles depositados en el banco, los "bonos de ladrillo". Acorde a ese módulo de inversión, las tipologías más pequeñas se afirmaron entonces, hasta llegar -desde hace varios años- a explicar el $80 \%$ de la producción anual. (Fundación de Estudios para Desarrollos Inmobiliarios, 2012)
} 
corredores de los principales accesos a la ciudad y en torno a las plazas. En este periodo se construyeron 2 millones de metros cuadrados nuevos en el casco fundacional de la ciudad (DataUrbis, 2011), casi 7 veces la superficie del casco fundacional completo. Si bien el proceso tuvo un breve estancamiento en 2009 por efecto de la crisis financiera internacional, ese mismo año el proceso de construcción continúa e incluso se acentúa a partir de la implementación de la normativa de usos del suelo que concedió ciertos beneficios constructivos. Este periodo se extiende hasta el año 2014, al año siguiente se produce un cambio de gestión a nivel nacional acompañado de un cambio en la política económica, con apreciación del tipo de cambio y aumento de las tasas de interés, lo que bajó el nivel de la actividad de la construcción y fomentó el mercado financiero.

A nivel local se realizan dos reformulaciones de la ordenanza de uso del suelo, en el año 2000 se sanciona la Ordenanza 9231/00, a partir de la cual se incrementa el potencial constructivo de la ciudad, y en el año 2010, se sanciona la ordenanza 10703/10. La primera extiende el área urbana en un $17 \%$ e incrementa la superficie permitida para la construcción de viviendas en altura en un $622 \%$ respecto de la ordenanza antecesora del año 1978. La segunda, volvió a intensificar los indicadores tantos constructivos como de ocupación del suelo, eliminó algunos artículos de protección y generó ambigüedades en el texto que permiten interpretaciones arbitrarias y dan oportunidad de mayor densificación habitacional. 


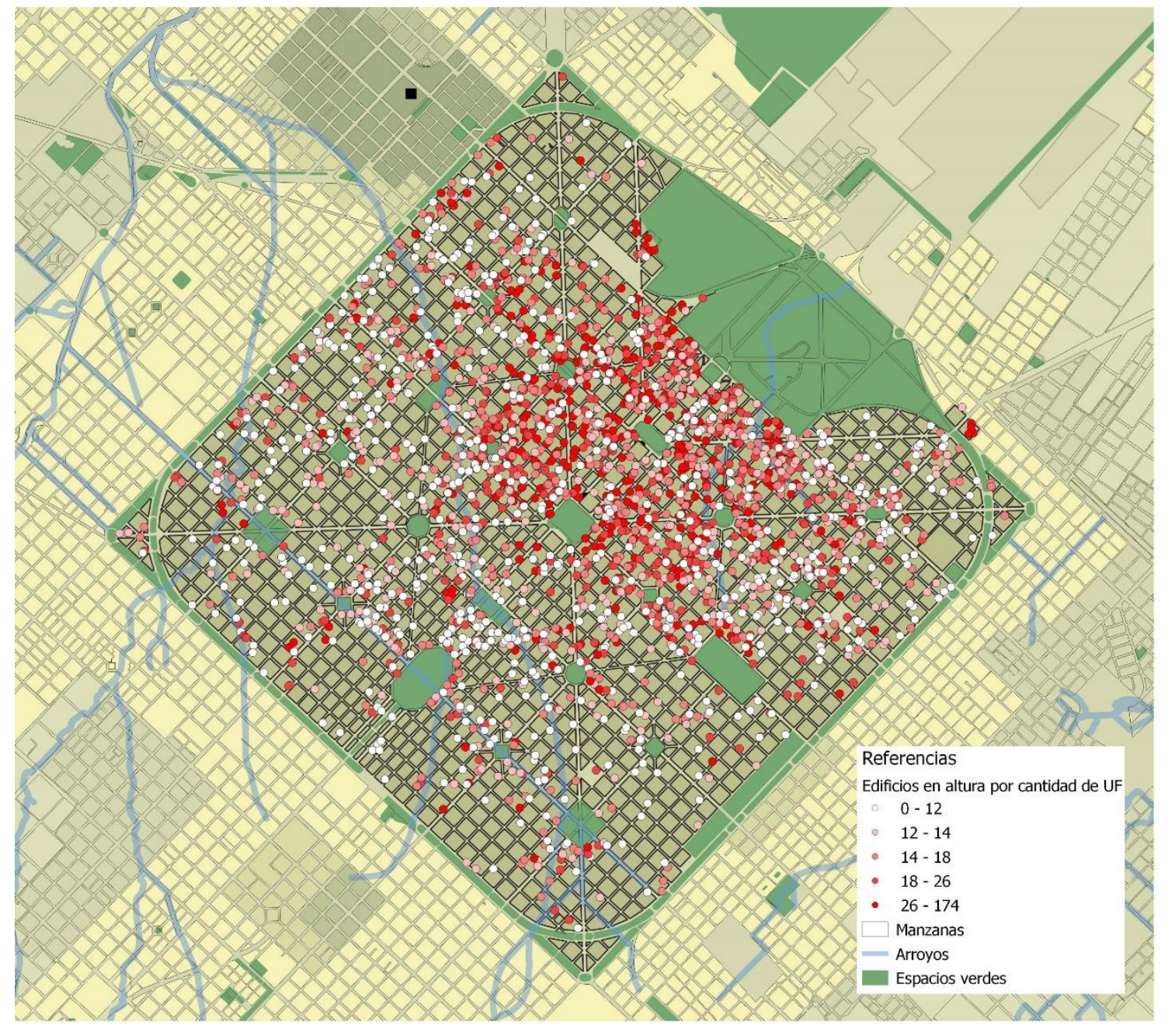

Imagen 9. Edificaciones Nuevas Ejes de desarrollo edilicio en La Plata 2004-2014. Fuente: Elaboración propia en base a relevamiento Google Earth.

Las acciones emprendidas a nivel local sumado al contexto macroeconómico, que generó un excedente de capitales que se volcaron hacia el mercado de la construcción, consolidan un periodo de densificación del parque habitacional de la ciudad que transforma nuevamente el paisaje urbano. Durante el periodo 2002 y 2009, la cantidad de metros cuadrados a construir autorizados por el Municipio en el casco fundacional se incrementó un $1.361 \%$. Este proceso genera impactos sobre el paisaje de la ciudad con la verticalización edilicia principalmente en los sectores de Av. 60, entre 1 y 14, Av. 1 entre 53 y 60, Av. 13, entre 42 y 64, Av. 19, entre 44 y 60, Av. 44 de 7 a 19 y en el entorno de la plaza Olazábal ( 7 y 38) continuando por la Av. 38 hasta 19, sectores que experimentan los cambios sufridos en el entorno de la Plaza Paso en la década del `90. 
Dicho proceso modificó la tendencia de tipologías construidas en el área central, donde hasta ese entonces predominaban las viviendas unifamiliares. De acuerdo con los datos censales de tipo de vivienda $^{22}$ (INDEC, 2010), podemos ver que en el año 2004 los porcentajes para las tipologías “casa" tenía una pequeña predominancia $(51 \%)$ por sobre la tipología "departamento" *(49\%) dentro del área central. En cambio, para el año 2014 la tipología "departamento" asciende del $61 \%$ del total de las viviendas. En la Imagen 10 se puede observar a partir del análisis de ofertas de departamentos de edificios en construcción, que las tipologías dominantes proponen unidades tipo monoambiente y un dormitorio.

Este patrón se relaciona con la rentabilidad que se obtiene por la venta de unidades, ya que al fraccionar más la superficie construida la ganancia es mayor, es decir que, este tipo de departamentos pequeños, tienden a ofrecer mayores y más rápidas ganancias. Este razonamiento es el que guía a los desarrolladores inmobiliarios, cuya motivación es mejorar los márgenes de ganancia. Asimismo, la oferta de departamentos está dirigida a un público que compra inmuebles como forma de inversión y no como vivienda propia por lo que la vivienda como producto se transforma en un 'comodity' y deja de ser un bien de uso. Este fenómeno hace que los compradores no se preocupen por la calidad habitacional tendiendo hacia la homogenización de la oferta con unidades de uno y dos ambientes.

\footnotetext{
${ }^{22}$ Los tipos de vivienda definidas por el INDEC para la aplicación metodológica define Casa como "vivienda con salida directa al exterior (sus habitantes no pasan por pasillos o corredores de uso común) construida originalmente para que habiten personas"; y Departamento como "vivienda que forma parte de un edificio o estructura con una entrada común que contiene por lo menos dos viviendas (o una vivienda y uno o más locales) a la que se accede a través de pasillos, escaleras, zaguanes o ascensores de uso común”.
} 


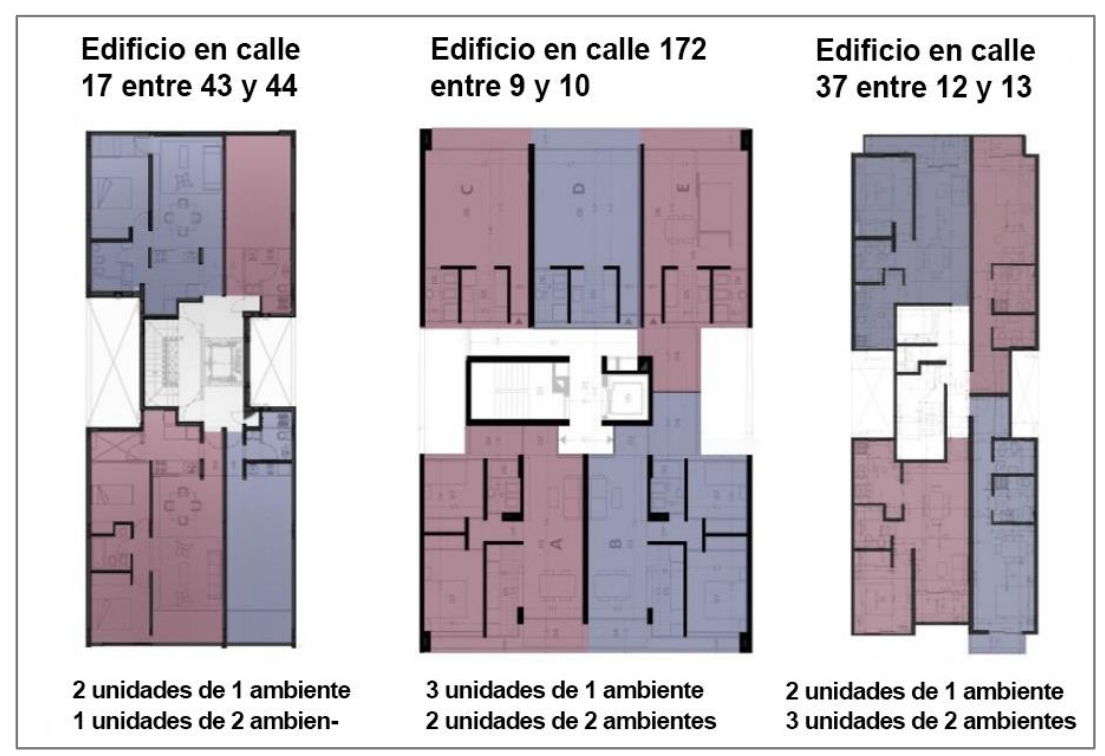

Imagen 10. Oferta de departamentos a la venta, planta tipo y unidades funcionales. Fuente: Elaboración propia en base a relevamiento en página web SIOC.

Asimismo, si comparamos el incremento del parque habitacional en el área central con el incremento de la población, vemos que no hay correlación (ver Tabla 4). El aumento de población equivale al 9\% entre 2004-2014, mientras que el incremento de viviendas durante el mismo periodo fue de $29 \%$. Dichos datos verifican que el incremento del parque habitacional es tres veces mayor que el incremento de la población, lo que arroja un índice de ocupación de 1.85 hab. /vivienda, muy por debajo del índice de ocupación del partido ${ }^{23}$ (2.55 hab. /Vivienda) y del índice provincial (2.91 hab. /Vivienda). Esto expone una diferencia entre los procesos de verticalización edilicia y los procesos de densificación poblacional.

\begin{tabular}{rrrr} 
AÑO & POBLACIÓN & VIVIENDA & INDICE DE OCUPACIÓN \\
\hline $\mathbf{2 0 0 4}$ & 189.452 & 80.114 & 2,36hab./viv \\
\hline $\mathbf{2 0 1 4}$ & 207.868 & 112.352 & $1,85 \mathrm{hab} . / \mathrm{viv}$ \\
\hline VARIACIÓN & $\mathbf{1 8 . 4 1 6}$ & $\mathbf{3 2 . 2 3 8}$ & \\
\hline
\end{tabular}

Tabla 4. Variación de población, hogar y vivienda en el área central de La Plata. Fuente: Elaboración Propia en base a Proyección censo 2001 y 2010, INDEC.

\footnotetext{
${ }^{23}$ La Plata presenta índices de ocupación menores en relación con los índices del país (2,87 hab. /vivienda), la provincia $(2,91)$ y la región metropolitana $(2,89)$. DataUrbis 2011
} 
Este fenómeno incide en otra variable, la redistribución de la población. La oferta de unidades del parque habitacional disponible repercute en la posibilidad de localización de la población y los diferentes tipos de hogares, ya que al homogeneizar la oferta habitacional tiende a limitar las opciones para los hogares que buscan viviendas dentro del área central, iniciando procesos de expulsión de hogares grandes del área central de la ciudad hacia la periferia.

Respecto al paisaje, en este periodo las transformaciones se profundizan y producen cambios más contundentes que afectan las componentes materiales y también las componentes simbólicas del paisaje. La verticalización del perfil de la ciudad en este periodo evidencia la superposición de distintas alturas permitidas por las sucesivas normativas urbanas (ver Imagen 11). Como se puede ver en la Imagen 12, se generan vistas de medianeras ciegas en distintos planos, que no son diseñadas, quedando como inconclusas a la espera del completamiento con otros edificios, situación que se extiende en tiempo y que deteriora el paisaje urbano. Asimismo, el paisaje en altura creado por estos edificios agrega el desafío de integrar la "quinta fachada" o vista de techo de las casas bajas, que no han sido diseñados como fachadas y que constituyen uno de los planos principales del paisaje en altura.
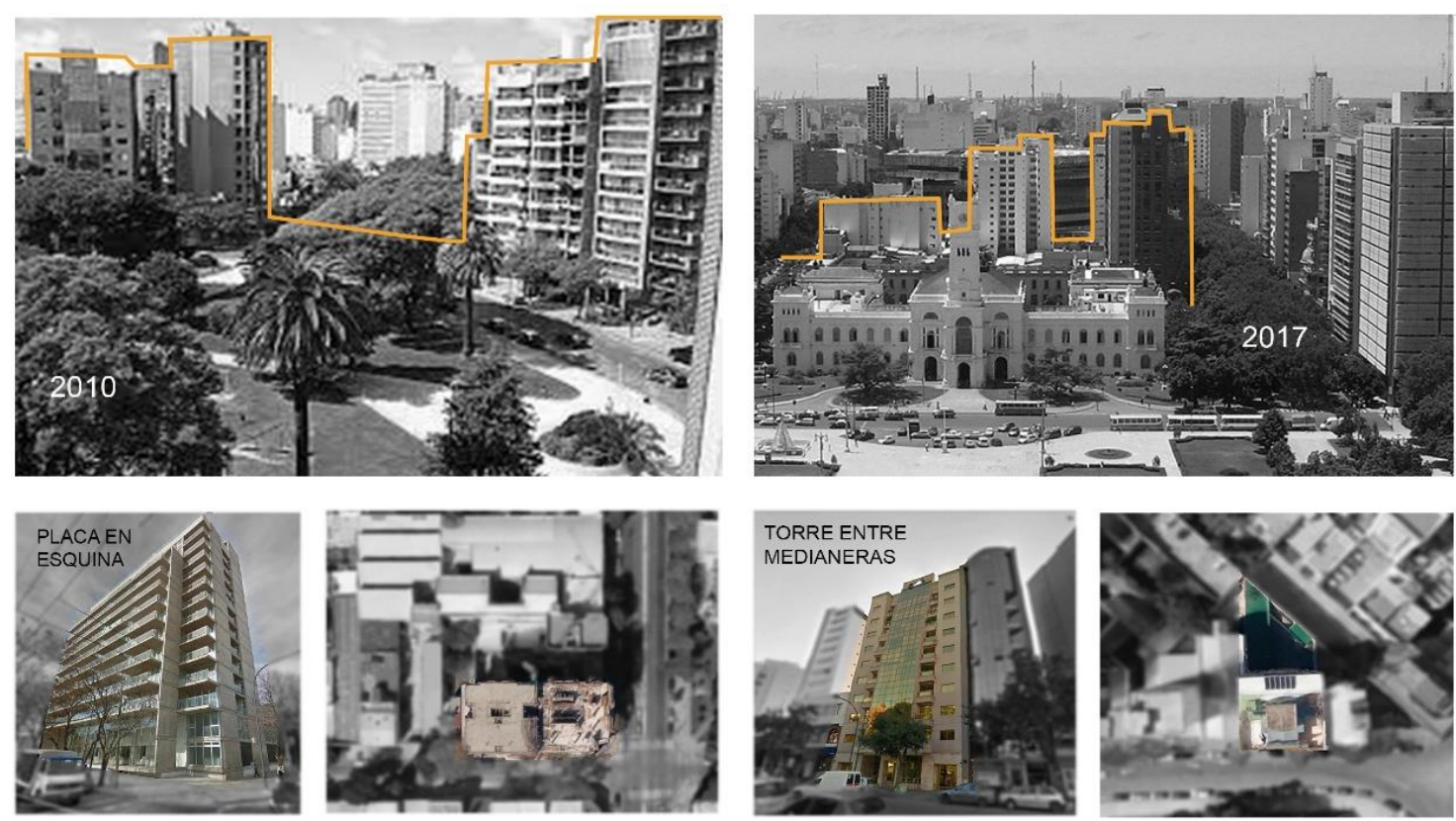

Imagen 11. Paisaje urbano y tipologías de vivienda, periodo. 2004-2014. Fuente: Elaboración propia en base a relevamiento Google Earth y página web: Fotos históricas de La Plata. 
La aparición de edificios en altura afecta al paisaje urbano de varias maneras, en términos patrimoniales se pierden fachadas históricas que son reemplazadas con fachadas estandarizadas y homogéneas. En términos visuales los aumentos de las alturas de construcción amplían los conos de sombra proyectados sobre la calle y modifican el crecimiento del arbolado público. También incide en términos funcionales, dado que cambia el modo de uso del espacio, la relación con la calle, el uso del espacio público y la dinámica urbana, ya que el aumento de viviendas induce el aumento de población y de movimiento en el área central, dando como resultado a nivel peatonal, veredas invadidas con accesos a los estacionamientos particulares de los edificios, quitando comunicación y contacto de las viviendas con la calle.
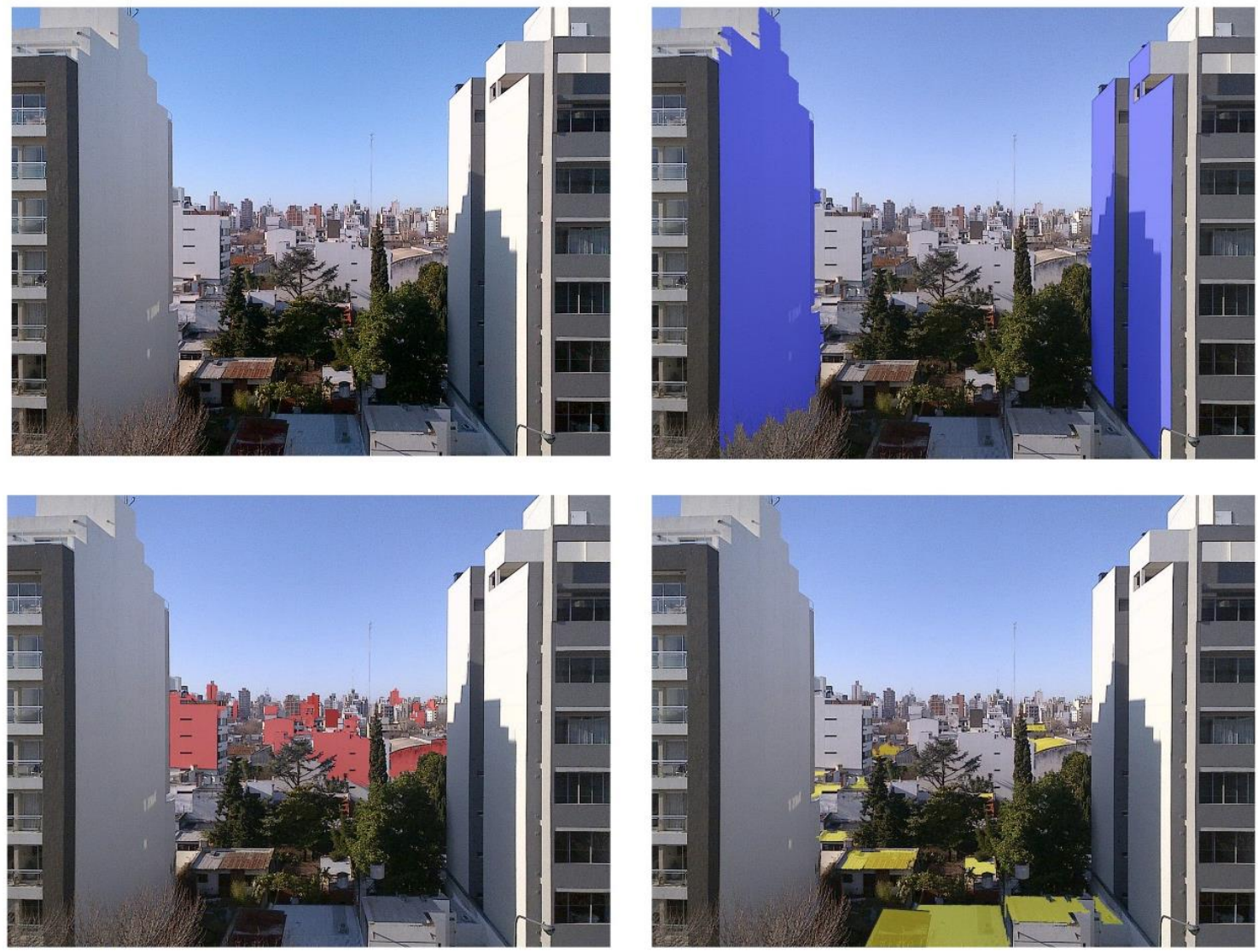

Imagen 12. Análisis de composición del paisaje, superposición de torres y medianeras. Fuente: Elaboración propia, fotos del autor 2018.

Asimismo, el proceso de verticalización implica una renovación edilicia que involucra edificios de carácter patrimonial, que estaban protegidos por el artículo 271 de la Ordenanza del año 2000, artículo que se elimina en la normativa de 2010 (ver Anexo 1). En 2008 el 59\% de los metros 
cuadrados de construcción aprobados ${ }^{24}$ se encuadran en la categoría “construcción y demolición”. Así también se registra en el mercado de tierra urbana, la oferta de lotes y terrenos para la venta con edificaciones en buenas condiciones, en algunos casos con edificaciones de valor patrimonial, ya que la venta de la capacidad constructiva del lote es mayor que el beneficio por la venta del inmueble. Dichos datos son indicativos del proceso de renovación edilicia en el área central, que reemplaza viviendas unifamiliares antiguas (y no tan antiguas) por edificios en altura. De esta manera se eliminan referencias simbólicas de la ciudad.

Para profundizar el análisis de las transformaciones materiales y simbólicas se requiere profundizar en un nivel de anclaje a partir de zonas testigos, donde se trabajan los datos con mayor precisión y con la opinión de los habitantes, para poder incorporar las dimensiones descriptivas del ambiente y las dimensiones que caracterizan la experiencia emocional, la valoración y la percepción del paisaje urbano. Dicho análisis se desarrolla en el siguiente capítulo.

${ }^{24}$ Dirección General de Estadística y Evaluación de Programas del Municipio. 
CAPITULO 5. La componente material de paisaje 


\section{Lo tangible y cuantificable en el paisaje}

A partir del análisis general del área central de La Plata se focalizó sobre dos zonas testigos, para realizar "análisis de sector" en cada caso y para poder cuantificar, espacializar y analizar los procesos de transformación y los efectos observados. De esta manera se abordaron dos sectores del casco fundacional, diferenciados en localización, niveles y diversidad de actividades y avance del proceso de densificación.

Como se ve en la Imagen 13, ambas zonas se encuentran sobre el eje de crecimiento Buenos Aires - La Plata. En su origen tuvieron un diseño simétrico, pero han tenido una evolución muy diferente en el tiempo. Una está ubicada hacia el norte del área central, ligada a la dinámica de la periferia norte y su conexión con Ciudad Autónoma de Buenos Aires (CABA). La otra zona testigo, está ubicada al sur del área central, ligada a dinámicas más endógenas. Ambas zonas presentan procesos de transformación diferentes respecto al espacio construido, al espacio público y a su organización social.

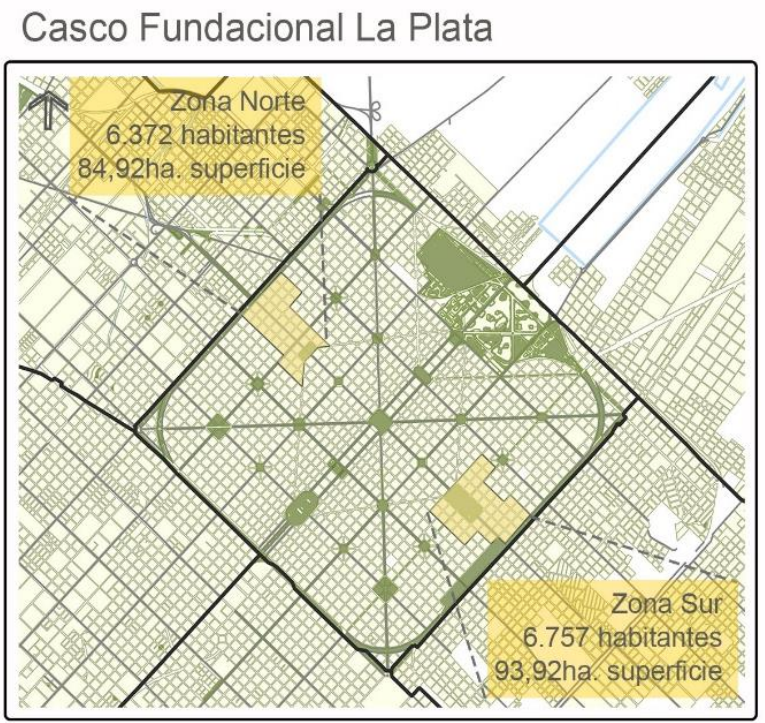

Imagen 13. Recorte espacial: Área central y zonas testigo seleccionadas. Fuente: Elaboración propia 2019. 
El recorte temporal corresponde al periodo de diez años de trasformaciones, iniciado en el año 2004, que se caracterizó por un fuerte incremento del parque habitacional local, y se extiende hasta el año 2014. Para analizar este periodo se toma información censal (población, hogares y viviendas) e imágenes satelitales (crecimiento del espacio construido) para construir la situación de inicio (2004) y final (2014) del periodo en cuestión.

El "análisis de sector" comprende la descripción, de las dimensiones trabajadas en el nivel contextual: configuración urbana desagregada en (a) configuración del espacio privado construido, que incluye los aspectos morfológicos y patrimoniales; (b) configuración del espacio público, que incluye aspectos ambientales y de movilidad y; (c) organización social, que apunta al reconocimiento de la funcionalidad y las características poblacionales.

\section{Caracterización y cuantificación de la componente material} en la Zona Norte

La zona Norte, ubicada dentro del casco fundacional, se encuentra comprendida entre la Av. 32 y la calle 41, y entre las calles 9 y 16 de la ciudad. En esta delimitación ${ }^{25}$ de 84.92 hectáreas, se agrupan 42 manzanas equivalente a 56.69 hectáreas, 20.17 hectáreas de superficie de calles, y 8.09 hectáreas de espacios verdes.

El tejido de la zona es predominantemente compacto, está constituido fundamentalmente por uso residencial con presencia de corredores comerciales sobre las avenidas. El perfil urbano presenta algunos edificios en altura, destinados a viviendas de uno y dos dormitorios. Hasta el año 2002 aproximadamente, se mantuvo la predominancia de las tipologías de vivienda unifamiliar y de alturas oscilantes entre uno y dos niveles.

\footnotetext{
${ }^{25}$ Esta delimitación corresponde a la clasificación del territorio platense en zonas de transporte, es un agrupamiento de radios censales, esta unidad trabaja con información de población hogar y vivienda y datos de transporte, permitiendo el abordaje del análisis material.
} 
Durante el periodo analizado se ha observado aumento del nivel de inversión inmobiliaria en la zona Norte, hecho que puede estar relacionado a dos factores. Por un lado, su ubicación intermedia entre el centro histórico de la ciudad y la periferia norte del Partido de La Plata (la zona más antigua y consolidada, y la de población predominante de altos y medio altos niveles de ingreso), y por el otro, con los cambios en la regulación del suelo que han aumentado su capacidad constructiva.

\section{ZONA NORTE - Manzana: av.13 - 14 - av.32 - 33}

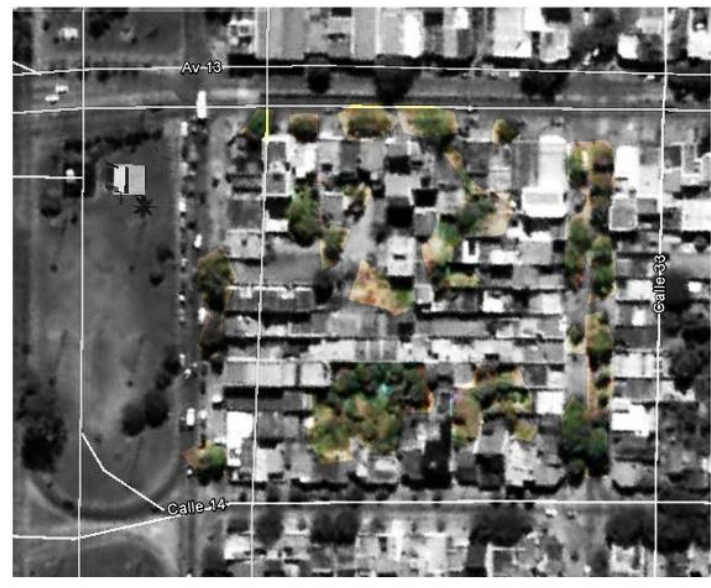

Año 2004

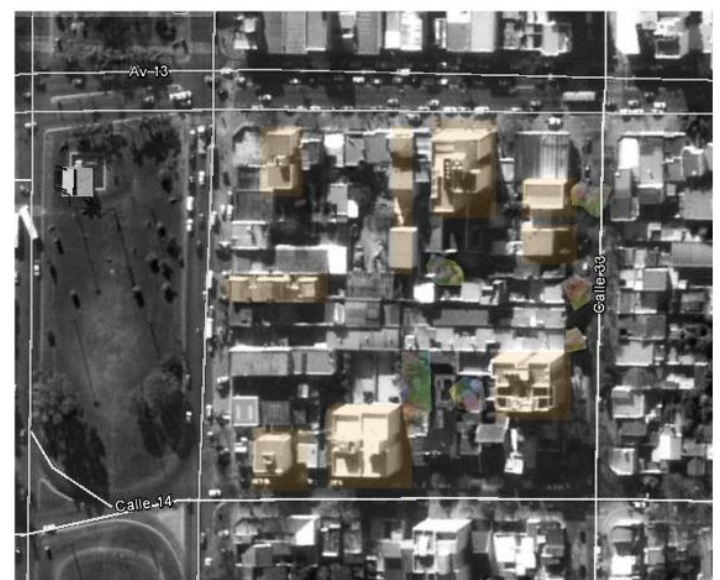

Año 2014

Imagen 14. Aparición de edificaciones en altura y pérdida de arbolado en una manzana, comparación año 2004-2014. Fuente: Elaboración propia en base a relevamiento de Google Earth.

En cuanto a la configuración del espacio privado construido se edificaron 103 edificios nuevos de viviendas multifamiliares, repartidos en construcciones de cinco niveles de altura (el 52\%), de seis niveles (el 39\%), de menos de cuatro niveles (el 2\%), y edificios de más de siete niveles de altura (el 7\%). La zona que, en el año 2004, era un barrio tranquilo de casas bajas y solo 49 edificios en altura, en 2004, se transformó a una zona con mucho tránsito y 152 edificios en altura en total. La cantidad de edificios en altura se triplicó en el periodo estudiado, pasando de 1 a 4 edificios por manzana. La Altura de edificios predominante por manzana pasó de 3 a 8 niveles, cambiando de forma significativa su perfil urbano (ver imagen 15). Sin embargo, el incremento es bajo en relación al potencial constructivo permitido por la normativa vigente. En este sentido la superficie construida por hectárea aumento levemente, de 1,45 ha. en 2004 a 1,54 ha en 2014. 


\section{PERFIL URBANO}

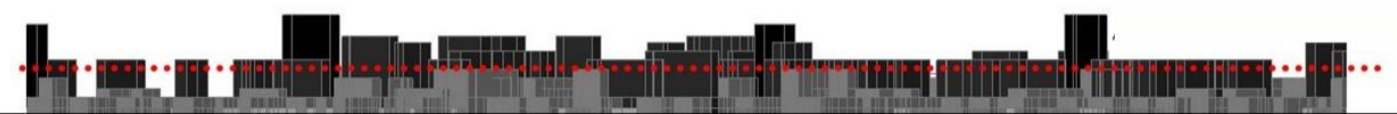

Imagen 15. Perfil urbano zona norte, año 2014. Fuente: Elaboración propia en base a trabajo de campo y relevamiento de Google Earth.

Desde el aspecto del patrimonio urbano la zona cuenta con pocos hitos urbanos, entre los cuales la Plaza Belgrano y la Asociación Cultural y Deportiva Reconquista son los más destacados. Estos resultan insuficientes comparado a la dimensión de la zona y a la cantidad de población. Por otro lado, según el catálogo de bienes patrimoniales ${ }^{26}$, en 2002 existían 378 edificaciones con distintos grados de valor patrimonial. Dicho parque patrimonial fue afectado por las construcciones de edificios de vivienda durante el periodo 2004-2014, perdiéndose 75 edificaciones de valor patrimonial.

\begin{tabular}{llcccccc} 
DIMENSION & VARIABLE & 2004 & 2014 & UNIDAD & VARIACION & CRITICIDAD \\
& $\begin{array}{l}\text { Cantidad de edificios en } \\
\text { altura por manzana }\end{array}$ & 1 & 4 & Unidad & $+210 \%$ & ALTA \\
\cline { 2 - 7 } $\begin{array}{l}\text { CONFIGURACION } \\
\text { ESPACIO }\end{array}$ & $\begin{array}{l}\text { Alturas de edificios } \\
\text { PRIVADO } \\
\text { PONSTRUIDO }\end{array}$ & $\begin{array}{l}\text { Superficie construida por } \\
\text { hectárea }\end{array}$ & 1,45 & 1,54 & M2/ha & $+7 \%$ & BAJA \\
\cline { 2 - 7 } & Hitos urbanos & 7 & 6 & Unidad & $-\mathbf{1 4 \%}$ & MEDIA \\
\cline { 2 - 7 } & Parque patrimonial existente & 378 & 303 & Unidad & $-\mathbf{2 0 \%}$ & MEDIA \\
\hline
\end{tabular}

Tabla 5. Comparación de variables de espacio construido de la zona norte. Fuente: Elaboración propia en base a trabajo de campo y relevamiento de Google Earth.

En cuanto a la configuración del espacio público en la actualidad, las plazas, parques, calles, ramblas y veredas disponibles, evidencian un cambio en el uso, con un marcado avance del protagonismo del automóvil y un retroceso de peatones y de utilización general del espacio público de recreación y paseos. La utilización de los espacios públicos en la zona es reducida.

\footnotetext{
${ }^{26}$ El catálogo de bienes patrimoniales fue elaborado a pedido del Municipio de La Plata para la normativa 9231/00 artículo 271 del año 2010. Ver anexo 1.
} 
Por un lado, se limita al uso deportivo de las áreas verdes ubicadas principalmente en el borde de la zona, y por el otro, las ramblas de la avenida son utilizadas como mercados de frutas y verduras.

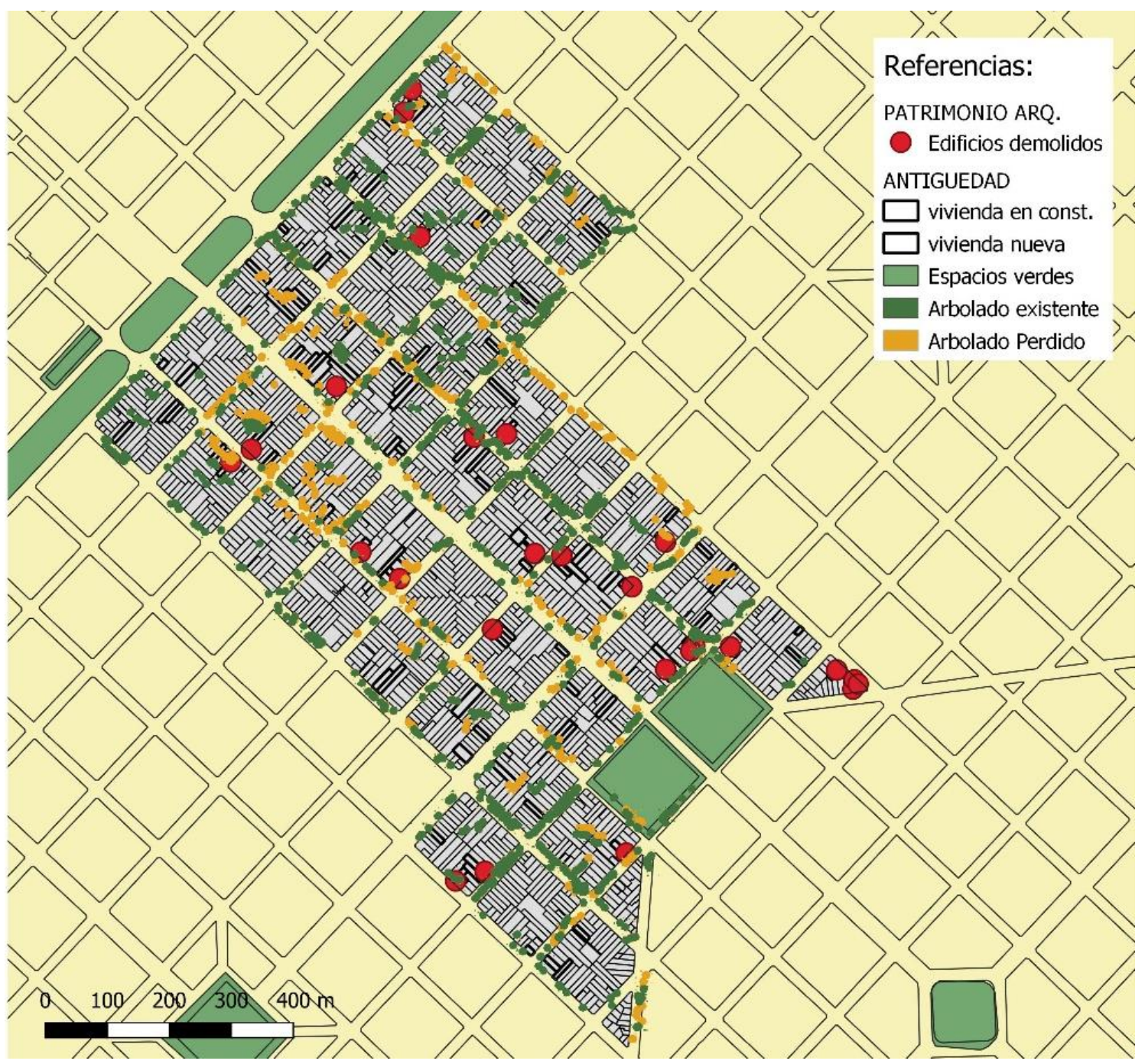

Plano 1. Relación entre edificaciones en altura y la pérdida de masa arbórea y de patrimonio arquitectónico, año 2014. Fuente: Elaboración propia en base a trabajo de campo y relevamiento de Google Earth.

No se registran actividades culturales permanentes en la zona, tampoco hay espacios culturales ni sociales reconocidos. Los espacios verdes, tanto la plaza como las veredas y las ramblas de las avenidas, tienen un lugar relegado como espacios públicos, son utilizadas como un lugar de tránsito entre la periferia norte y el centro comercial de la ciudad, incluso se prioriza la infraestructura de transporte por sobre el espacio público, al punto que la plaza Belgrano está dividida en dos partes por la Av. 13. 
Los espacios verdes de uso público no se han incrementado en correlación con el incremento del parque habitacional, de manera que la cantidad de espacio verde por habitante ha ido modificándose conjuntamente con la variación poblacional, pasando de $12 \mathrm{~m} 2 / \mathrm{hab}$. en 2004 a 10 m2/hab. en 2014, llegando al límite óptimo de espacios verdes por habitante que establece la organización mundial de la salud - OMS. Frente a la capacidad constructiva normativa de esta zona, que permitiría aumentar la densidad poblacional seis veces más, y sin posibilidad de expandir la superficie de espacio verde, se alcanzaría una relación crítica de $6 \mathrm{~m} 2 / \mathrm{hab}$.

Asimismo, la vegetación del espacio público se ve disminuida por la construcción de edificios. En el periodo de estudio la masa arbórea disminuyó de 9,3 $\mathrm{m} 2$ a $8 \mathrm{~m} 2$ por hectárea lo que implica una pérdida del 14\% de vegetación, en una zona de tradicional, con poca cantidad de árboles.

\begin{tabular}{|c|c|c|c|c|c|c|}
\hline DIMENSION & VARIABLE & 2004 & 2014 & UNIDAD & VARIACION & CRITICIDAD \\
\hline \multirow{4}{*}{$\begin{array}{l}\text { CONFIGURACION } \\
\text { ESPACIO } \\
\text { PÚBLICO }\end{array}$} & Masa arbórea & 9,3 & 8 & $\mathrm{~m} 2$ & $-14 \%$ & ALTA \\
\hline & Esp. Verde libre / hab. & 12 & 10 & $\mathrm{~m} 2 / \mathrm{hab}$ & $-21 \%$ & ALTA \\
\hline & Cantidad de autos & 1.494 & 7.064 & Unidad & $+373 \%$ & ALTA \\
\hline & $\begin{array}{l}\text { Capacidad de } \\
\text { estacionamiento }\end{array}$ & 1,07 & 0,27 & est./autos & $-75 \%$ & ALTA \\
\hline
\end{tabular}

Tabla 6. Comparación de variables de espacio público de la zona norte. Fuente: Elaboración propia en base a trabajo de campo y relevamiento de Google Earth.

En el aspecto de movilidad, se registra un aumento de las tasas de motorización de las personas y hogares. A nivel global en la ciudad, había 4,5 habitantes por auto en 2001 mientras que se llegó a 1,2 habitantes por auto en 2014. Esto significa un aumento de la cantidad de autos propios de los residentes (nuevos y antiguos) de la zona norte, pero también significa un aumento de automóviles “de paso", por su localización estratégica entre la periferia norte y el centro histórico y administrativo de la ciudad. 
Con respecto a los autos propios de la zona norte, crecieron un $373 \%$ en el periodo de estudio, de 1.494 autos en 2004 a 7.064 autos en 2014. Dicho incremento impacta no solamente en la congestión vehicular cotidiana, sino además en la capacidad de estacionamiento disponible, que pasó de tener plena disponibilidad de estacionamiento en 2004, con 1.07 estacionamiento por auto, a disminuir la capacidad en 75\% en 2014. Esta situación se refleja en el uso habitual de las veredas peatonales como lugares de estacionamiento de los vecinos de la zona norte. Es así que la capacidad de estacionamiento en el sector no estaría cubierta por completo, ya que no se previó en todos los casos de nuevos edificios de viviendas que se construyeron en la zona norte, un módulo de estacionamiento por unidad funcional, acorde a la tasa de motorización mínimas de los hogares de ingresos medio-altos, como los que se pueden localizar en los nuevos edificios de esta zona.

Al mismo tiempo, en la zona se suma el tránsito 'de paso', por efecto del incremento del índice de motorización y por tratarse de una zona de acceso al microcentro mediante el corredor de Av. 13, que se constituye en conexión de la periferia norte con el área central, lo que implica un problema para el uso de estacionamiento sobre la calle.

Si bien la densidad en la zona norte aún guarda cierta relación con los corredores principales, la distribución de las edificaciones nuevas, se aleja de la lógica de densificación sobre corredores. En el Plano 2 se puede ver como las nuevas edificaciones comienzan a diseminarse por el sector sin acentuar la verticalización de las avenidas principales, que son las calles donde se concentran los recorridos del transporte colectivo, los comercios y servicios. Este efecto no contribuye a una sinergia entre la densificación del área central y la reducción del uso de transporte privado. 


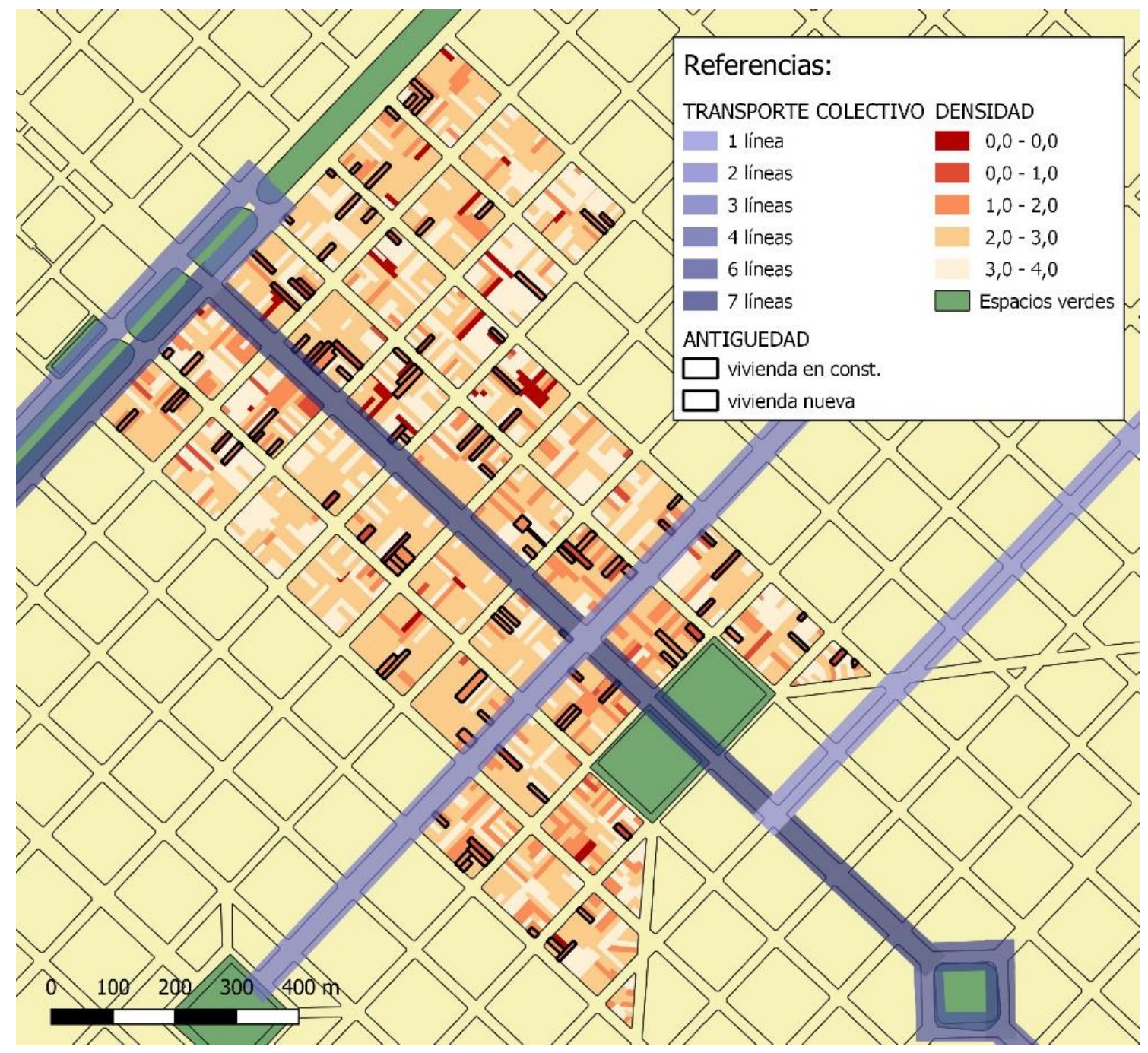

Plano 2. Relación entre densidad de población, nuevos edificaciones y accesibilidad a transporte masivo, año 2014. Fuente: Elaboración propia en base a trabajo de campo y datos censo INDEC (2010).

En términos de organización social, se puede observar que los aspectos de funcionalidad de la zona mejoraron levemente. Por un lado, se observa que el porcentaje de actividad comercial se mantuvo en el 99\% entre 2004 y 2014, con un leve incremento de la actividad comercial sobre los ejes de desarrollo de las avenidas 13 y 38 . Por otro lado, ha disminuido la escasa oferta de actividades culturales en la zona, las cuales representan el $0.31 \%$ del total de actividades en la zona en 2004 y solo el $0.26 \%$ de actividad recreativa del total de actividades en 2014 .

En cuanto a aspectos demográficos, la densidad de población no presenta mucha fluctuación, dado que pasó de 66 habitantes por hectárea en 2004 a 68 en 2014, pese al aumento del parque habitacional. Si bien la construcción de edificios implicaría un incremento potencial de 1.756 
nuevos habitantes en la zona (un incremento del 28\%), según datos censales el sector pasó de 6.094 habitantes en 2004 a 6.278 habitantes en 2014, lo que significa un incremento intercensal de casi el 3\%, muy lejos incluso del incremento total del partido que ronda el $13 \%{ }^{27}$. Dichas cifras reflejan una capacidad ociosa de los departamentos nuevos y una utilización de la zona norte como inversión con fines especulativos.

\begin{tabular}{|c|c|c|c|c|c|c|}
\hline DIMENSION & VARIABLE & 2004 & 2014 & UNIDAD & VARIACION & CRITICIDAD \\
\hline \multirow{6}{*}{$\begin{array}{l}\text { ORGANIZACIÓN } \\
\text { SOCIAL }\end{array}$} & Actividad comercial & $99,40 \%$ & $99,50 \%$ & porcentaje & $+0.1 \%$ & BAJA \\
\hline & Actividad recreativa & $0,31 \%$ & $0,26 \%$ & porcentaje & $-16 \%$ & BAJA \\
\hline & Densidad de población & 66 & 68 & $\mathrm{Hab} / \mathrm{ha}$ & $+3 \%$ & BAJA \\
\hline & $\begin{array}{l}\text { tamaño de hogar } \\
\text { predominante ( } 1 \text { y } 2 \\
\text { personas) }\end{array}$ & $56 \%$ & $64 \%$ & porcentaje & $+17 \%$ & MEDIA \\
\hline & $\begin{array}{l}\text { grupo etario } \\
\text { predominante (20-39 } \\
\text { años) }\end{array}$ & $33 \%$ & $38 \%$ & porcentaje & $+13 \%$ & MEDIA \\
\hline & $\begin{array}{l}\text { nivel educativo } \\
\text { predominante } \\
\text { (universitarios) }\end{array}$ & $39 \%$ & $43 \%$ & Porcentaje & $+23 \%$ & MEDIA \\
\hline
\end{tabular}

Tabla 7. Comparación de variables de organización social de la zona norte. Fuente: Elaboración propia en base a trabajo de campo y datos censo INDEC $(2001,2010)$

Respecto a la población, sí se verifica una variación en las características de la población. La población joven, de 20 a 39 años de edad, pasó de representar el 33\% de la población en 2004 al $38 \%$ en 2014, siendo la única franja etaria que incrementó su porcentaje durante este periodo. Así mismo, el porcentaje de población con estudios universitarios se incrementó, de 39\% en 2004 al $43 \%$ en 2014, siendo el grupo con mayor incremento intercensal, frente a los grupos con estudios primarios y secundarios que incluso disminuyeron su representación en el sector. Dichas cifras indican una tendencia de cambio de perfil poblacional que se orienta hacia un barrio con una población joven y profesional.

\footnotetext{
${ }^{27}$ El partido de La Plata tiene 649.613 habitantes según el censo (INDEC, 2010), 75.244 más que el censo anterior del 2001. Es decir, su población creció un 13,1\% en nueve años; similar al crecimiento provincial pero superior al 9,4\% nacional y al 10,7\% de la Región Metropolitana de Buenos Aires (RMBA). (DataUrbis, 2011)
} 
Esta tendencia de cambio de perfil también modifica el tamaño de hogar predominante, incrementando la cantidad de hogares pequeños (de 1 y 2 personas), que pasan de representar el $56 \%$ en 2004 al 64\% del total de los hogares del sector en 2014. Este incremento tiene relación con la diversidad de tipo de vivienda y la incorporación de nuevas tipologías. En la zona los edificios en altura se destacaban en el área solamente como hecho aislado y sobre las avenidas principales, pero con el incremento de la capacidad constructiva y la redistribución del potencial constructivo, introducidos a la normativa de regulación del suelo, los edificios en altura se multiplicaron en la zona. En términos cuantitativos los departamentos pasaron de representar el $35 \%$ de las viviendas en 2004 al 49\% en 2014, equiparando la cantidad de viviendas tipo "casa". Esto se deriva en una reducción de la superficie de las viviendas, y de la cantidad de dormitorios por vivienda, lo que desalienta la permanencia de hogares grandes en el sector.

En la zona norte las transformaciones del paisaje urbano son rápidas e intensas, a partir de la construcción de edificios en altura que alteran la apariencia del paisaje y también su funcionamiento. Los impactos más importantes afectan lo ambiental y patrimonial y el uso de los espacios públicos y actividades colectivas, impactando en la organización social, en los aspectos demográficos, transformando el perfil de población residente.

\section{Caracterización y cuantificación de la componente material} en la Zona Sur

La zona Sur, ubicada también dentro del casco fundacional, se encuentra comprendida entre la calle 64 y la Av. 72, y entre las calles 8 y 16 de la ciudad. En esta delimitación ${ }^{28}$ de 93.92

\footnotetext{
${ }^{28}$ Esta delimitación corresponde a la clasificación del territorio platense en zonas de transporte, es un agrupamiento de radios censales, esta unidad trabaja con información de población hogar y vivienda y datos de transporte, permitiendo el abordaje del análisis material.
} 
hectáreas, 57.63 hectáreas agrupadas en 40 manzanas, 2.12 hectáreas de superficie de calles y 15.09 hectáreas de espacios verdes.

El área se estructura a partir de dos espacios verdes públicos, el Parque Saavedra y las plazoletas de la Avenida Circunvalación. El tejido predominante en esta zona es de característica residencial y compacta, con tipologías de vivienda unifamiliares y de alturas oscilantes entre uno y dos niveles, con algunos edificios en altura aislados. Sobresale la presencia de una manzana atípica dentro del tejido, construida en la década de 1970, que invierte la relación de ocupación tradicional y supera la altura promedio alcanzando los 15 niveles de altura.

\section{ZONA SUR- Manzana: 65 - av.66 - 9 - 10}

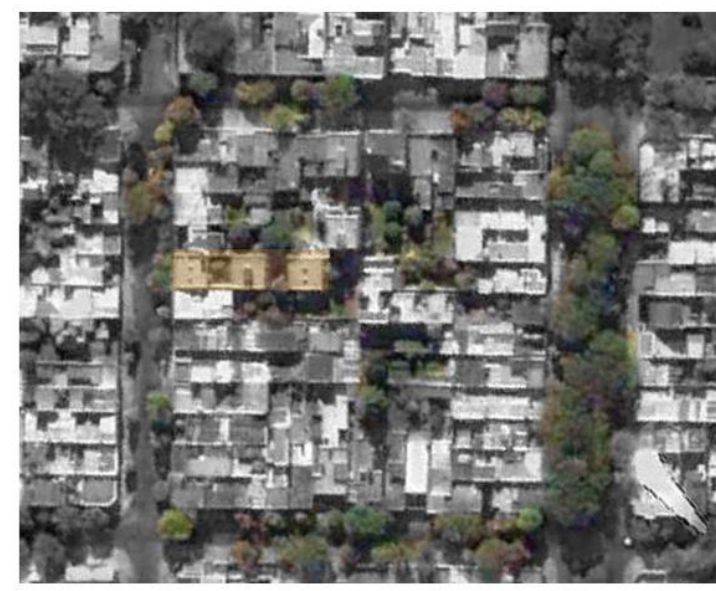

Año 2004

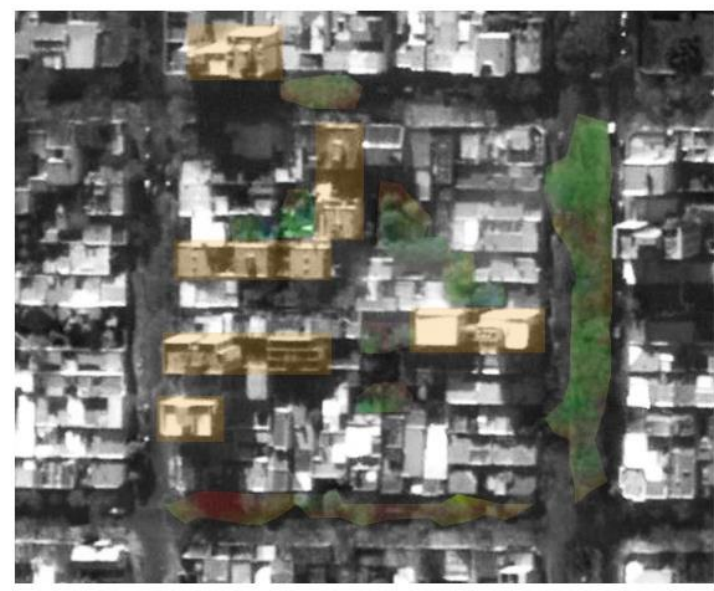

Año 2014

Imagen 16. Aparición de edificaciones en altura y pérdida de arbolado en una manzana, comparación año 2004-2014. Fuente: Elaboración propia en base a relevamiento de Google Earth.

Respecto a la configuración del espacio privado construido, durante el periodo de análisis, se construyeron 46 nuevos edificios en altura de viviendas multifamiliares, repartidas en construcciones de cinco niveles de altura (el 8\%), de seis niveles (el 19\%), de cuatro o menos niveles (el 54\%), y edificios de siete o más niveles (el 19\%). De esta manera, el sector ha transformado su paisaje, pasando de ser un barrio de casas bajas y con un total de 35 edificios en altura en el año 2004, a ser una zona con más movimiento y 81 edificios en altura en total en 2014. Si bien se duplicó la cantidad de edificios en altura existentes en 2004, el incremento resulta bajo en relación a la capacidad constructiva normativa en esta zona. 
En este sentido, la superficie construida por hectárea aumentó solo un $8 \%$, pasó de 1,20ha. en 2004 a 1,30ha. en 2014. En relación con la altura predominante por manzana, el sector pasó de 3 niveles de altura en 2004 a 6 niveles en 2014. Si bien se duplica la altura predominante, si analizamos el perfil urbano en su conjunto, éste se mantiene bajo y con gran compacidad entre alturas, como se puede apreciar en la Imagen 17.

\begin{tabular}{|c|c|c|c|c|c|c|}
\hline DIMENSIÓN & VARIABLE & 2004 & 2014 & UNIDAD & VARIACIÓN & CRITICIDAD \\
\hline \multirow{5}{*}{$\begin{array}{l}\text { CONFIGURACION } \\
\text { ESPACIO } \\
\text { PRIVADO } \\
\text { CONSTRUIDO }\end{array}$} & $\begin{array}{l}\text { Cantidad de edificios en } \\
\text { altura por manzana }\end{array}$ & 35 & 81 & unidad & $+100 \%$ & MEDIA \\
\hline & $\begin{array}{l}\text { Alturas de edificios } \\
\text { predominante por } \\
\text { manzana }\end{array}$ & 3 & 6 & pisos & $+100 \%$ & MEDIA \\
\hline & $\begin{array}{l}\text { Superficie construida por } \\
\text { hectárea }\end{array}$ & 1,2 & 1,3 & $\mathrm{~m} 2 / \mathrm{ha}$ & $+8 \%$ & BAJA \\
\hline & Hitos urbanos & 14 & 14 & unidad & $=0 \%$ & BAJA \\
\hline & $\begin{array}{l}\text { Parque patrimonial } \\
\text { existente }\end{array}$ & 460 & 440 & unidad & $-4 \%$ & MEDIA \\
\hline
\end{tabular}

Tabla 8. Comparación de variables de espacio construido de la zona sur. Fuente: Elaboración propia en base a trabajo de campo y relevamiento de Google Earth.

Según el catálogo de Bienes Patrimoniales ${ }^{29}$, en la zona existían 460 edificaciones con distinto grado de este valor, de las cuales se perdieron veinte que representan un $4 \%$ durante el periodo 2004-2014. Además, el sector presenta varios hitos urbanos, 14 en total, los cuales se conservaron en el tiempo e incluso se consolidaron en el imaginario social. Durante este periodo se manifestó un proceso de recuperación del patrimonio urbano del barrio. Ejemplo de ello es la recuperación de la Rambla de Av. 72 por donde pasaba la antigua traza del tren, la cual fue puesta en valor y acondicionada para actividades recreativas y consolidada como espacio colectivo de la ciudad y de la zona. Ligada a este espacio abierto se produjo la reapertura y recuperación de la vieja estación provincial para actividades educativas, culturales y recreativas, poniendo así también en valor las antiguas instalaciones del ferrocarril, que se encontraban abandonadas.

\footnotetext{
${ }^{29}$ El catálogo de bienes patrimoniales fue elaborado para la normativa 9231/00 artículo 271 del año 2010. Ver capítulo 4.
} 


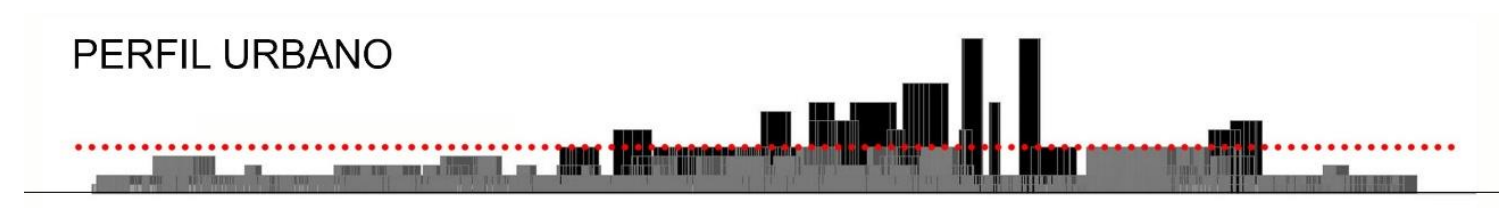

Imagen 17. Perfil urbano zona sur, año 2014. Fuente: Elaboración propia en base a trabajo de campo y relevamiento de Google Earth.

Con respecto a la configuración del espacio público, plazas, ramblas calles y veredas, son espacios muy importantes en la zona, en ellos se organizan una feria artesanal autogestionada, una biblioteca popular, un centro de entretenimiento infantil, un taller de escultura, y un centro cultural, todas iniciativas de la población que encuentran en esos espacios públicos un ámbito para actividades colectivas. También la actividad deportiva en los espacios públicos, tanto el Parque Saavedra como las ramblas de la Avenida de Circunvalación y el predio de la Estación Meridiano $\mathrm{V}$, denotan una buena relación de los habitantes del área con los espacios públicos de la zona.

Si bien los espacios verdes de uso público no se han incrementado en cantidad, se puede afirmar que se ha ampliado el uso de las áreas verdes disponibles que antes estaban abandonadas y hoy tienen mantenimiento y actividad intensa. En ese sentido, la relación entre espacios verdes y cantidad de habitantes ha disminuido levemente, acompañando el incremento de población, que pasó de $24 \mathrm{~m}^{2} / \mathrm{hab}$. en 2004 a $22 \mathrm{~m}^{2} /$ hab. en 2014. Sin embargo, dicha relación es muy superior en comparación con otras áreas de la ciudad y con lo establecido por la OMS (mínimo de $\left.10 \mathrm{~m}^{2} / \mathrm{hab}.\right)^{30}$.

\footnotetext{
${ }^{30}$ La Organización Mundial de la Salud estipula $10 \mathrm{~m}^{2} / \mathrm{hab}$. como la relación óptima entre espacios verdes y población,
} 


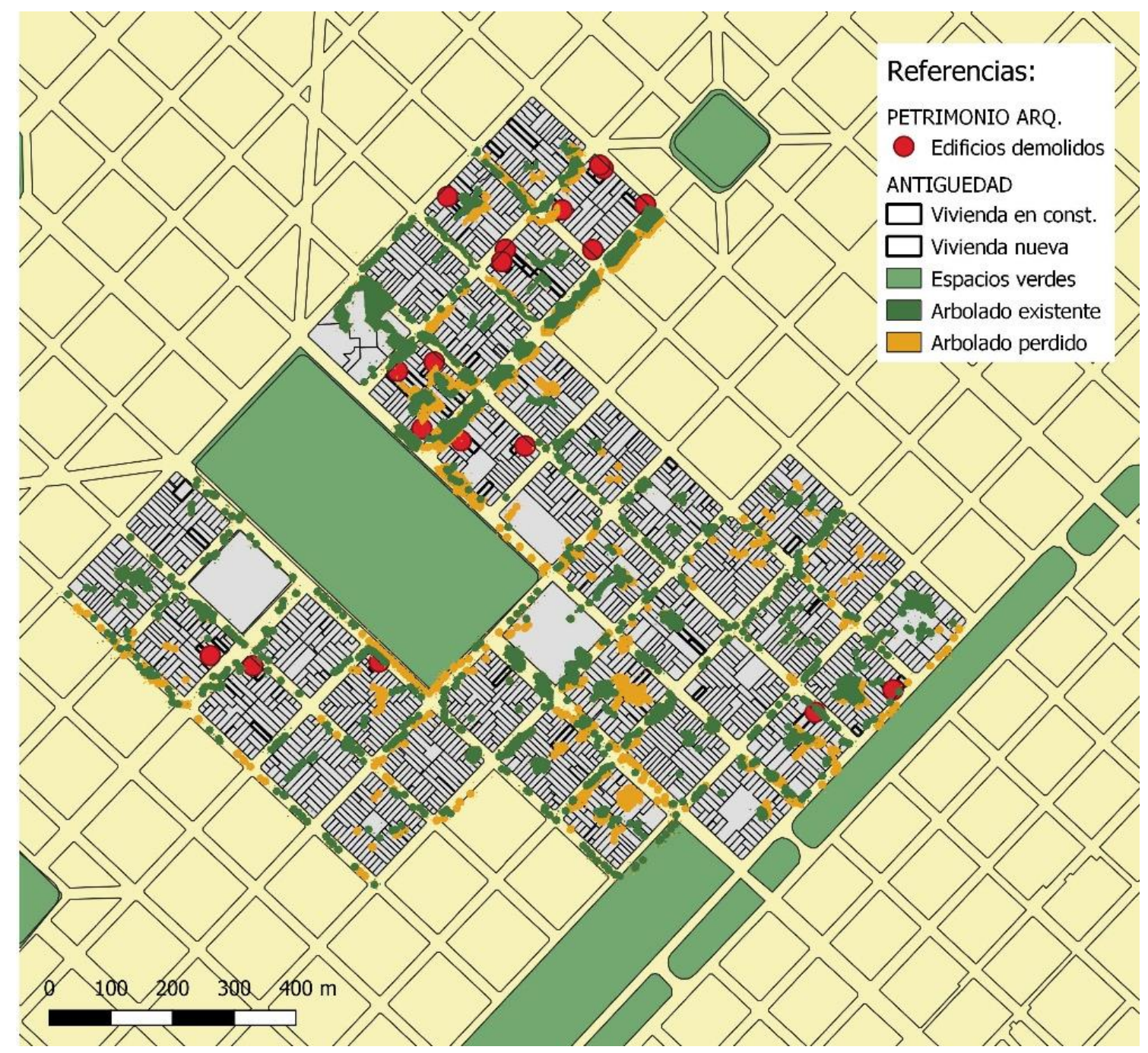

Plano 3. Relación entre edificaciones en altura y la pérdida de masa arbórea y de patrimonio arquitectónico en la zona sur, año 2014. Fuente: Elaboración propia en base a trabajo de campo y relevamiento de Google Earth.

La zona sur se destaca por la presencia de vegetación, tanto en el parque Saavedra como en las veredas y ramblas de toda su extensión. Durante el periodo estudiado, esta característica se conservó, la masa arbórea registró apenas un 4\% de reducción de la superficie cubierta por árboles (ver Plano 3). Por esto la apariencia de la zona se mantiene con fuerte presencia de vegetación en todo el espacio público.

Acerca de la movilidad los cambios están vinculados al índice de motorización, tal como se ha mencionado anteriormente (4,5 hab./auto en 2001 - 1,2 hab./auto en 2014), lo que en el sector implicó un incremento del $323 \%$ en la cantidad de autos residentes en la zona, pasando de 1.382 autos en 2004 a 5.848 autos en 2014. Dicho incremento impacta en la capacidad de 
estacionamiento disponible en el sector, que pasó de tener el doble de estacionamiento necesarios, con 2,05 estacionamientos por autos en 2004 , a 0,34 estacionamientos por autos, un $83 \%$ menos en 2014. La capacidad de estacionamiento estaría sobrepasada. Por otro lado, al ser una zona de paso, con servicios barriales, no presenta niveles de congestión importantes, exceptuando el área entorno al Hospital de Niños.

\begin{tabular}{llcccccc} 
DIMENSION & VARIABLE & 2004 & 2014 & UNIDAD & VARIACION & CRITICIDAD \\
\cline { 2 - 7 } $\begin{array}{l}\text { CONFIGURACION } \\
\text { ESPACIO } \\
\text { PÚBLICO }\end{array}$ & \begin{tabular}{l} 
Masa arbórea \\
\cline { 2 - 7 }
\end{tabular} & \begin{tabular}{l} 
Esp. Verde libre / hab. \\
\cline { 2 - 7 }
\end{tabular} & 24 & 22 & $\mathrm{~m} 2 / \mathrm{hab}$ & $-8 \%$ & ALTA \\
\cline { 2 - 7 } & $\begin{array}{l}\text { Cantidad de autos } \\
\text { Capacidad de }\end{array}$ & 1.382 & 5.848 & unidad & $=323 \%$ & ALTA \\
\hline
\end{tabular}

Tabla 9. Comparación de variables de espacio público de la zona sur. Fuente: Elaboración propia en base a trabajo de campo y relevamiento de Google Earth.

En lo que concierne a la organización social, el aspecto funcional se transformó, profundizando el perfil cultural de la zona. Por un lado, el porcentaje de actividad comercial se incrementó levemente del $71 \%$ en 2004 al $73 \%$ en 2014 . Dichas actividades se concentran sobre las avenidas que estructuran el sector, y son principalmente actividades gastronómicas. Por otro lado, las actividades culturales y deportivas se acrecentaron, la actividad recreativa pasó de representar el $2 \%$ al 3\% del total de actividades en 2014, lo que representa un incremento del $50 \%$ en diez años.

En cuanto a los aspectos demográficos, la densidad de la población se incrementó levemente, pasando de 65 habitantes por hectárea en 2004 a 69 en 2014. Si bien la construcción de edificios implicaría un aumento potencial de 2.017 nuevos habitantes en la zona, es decir un crecimiento del 29\%. Sin embargo, a partir de los datos censales se corrobora que el incremento de habitantes en la zona fue de solo el 7\%, la mitad del porcentaje que registró el partido en total, que ronda el $13 \%{ }^{31}$. Dichas cifras reflejan una capacidad ociosa de los departamentos construidos en este periodo en el sector.

\footnotetext{
${ }^{31}$ El partido de La Plata tiene 649.613 habitantes según el censo (INDEC, 2010), 75.244 más que el censo anterior del 2001. Es decir, su población creció un 13,1\% en nueve años; similar al crecimiento provincial pero superior al 9,4\% nacional y al 10,7\% de la Región Metropolitana de Buenos Aires (RMBA). (DataUrbis, 2011)
} 


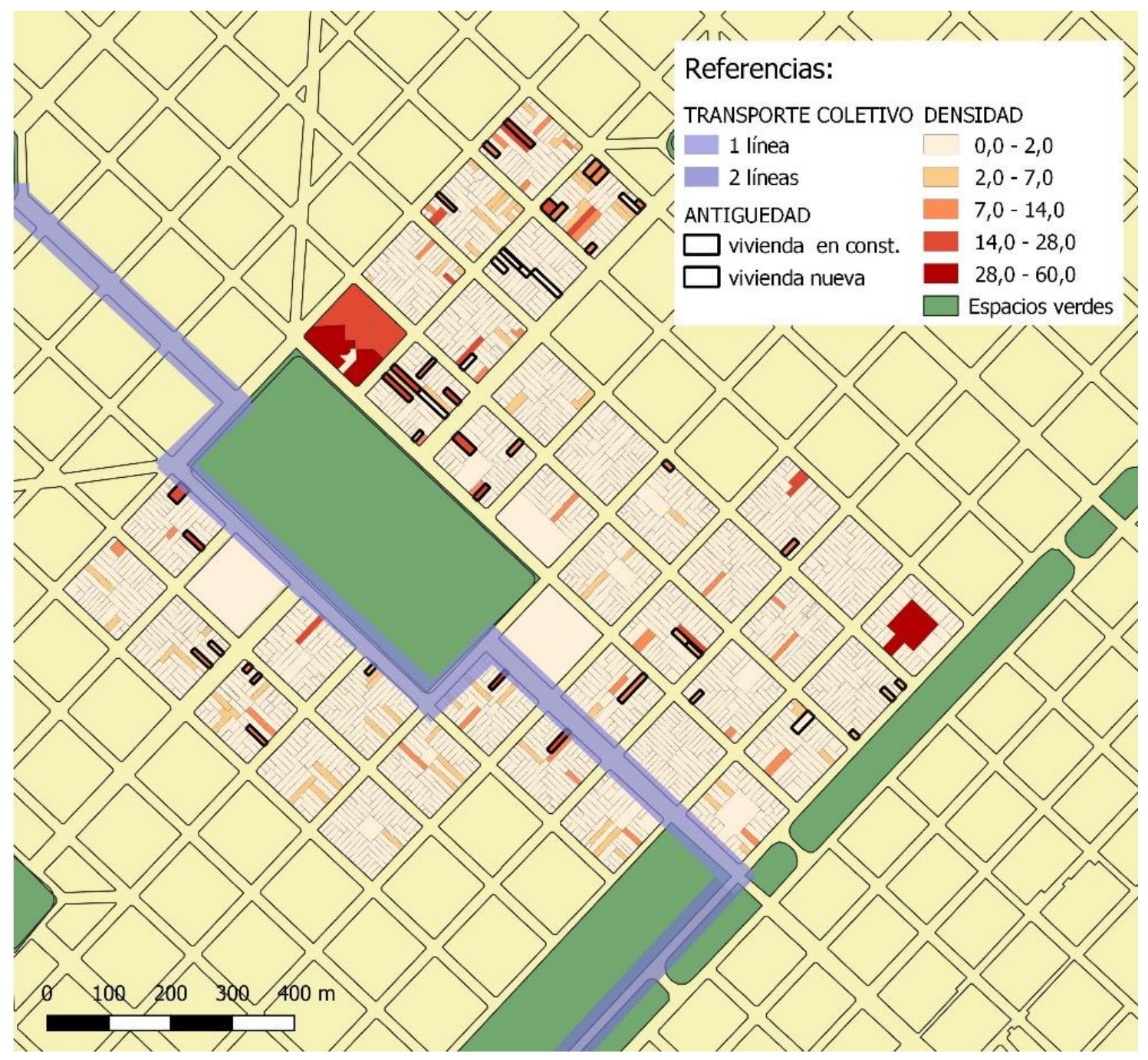

Plano 4. Relación entre densidad de población, nuevos edificaciones y accesibilidad a transporte masivo en la zona sur, año 2014. Fuente: Elaboración propia en base a trabajo de campo y datos censo INDEC (2010).

En la población, sí se verifica una variación en las características de edad, tamaño de hogar y nivel de instrucción. Por un lado, se incrementó la cantidad de población joven, de entre 20 a 39 años de edad, que pasó de representar el 33\% de la población en 2004 al 38\% en 2014, siendo la única franja etaria que se incrementó en el sector. Por otro lado, también se incrementó el porcentaje de población con estudios universitarios, que pasó del $40 \%$ en 2004 al 49\% en 2014 , siendo el grupo con mayor incremento intercensal, frente a los grupos con estudios primarios y secundarios que incluso disminuyeron en este sector. Dichas cifras indican una tendencia de cambio de perfil poblacional que, al igual que en la zona norte, se orienta hacia un barrio con una población joven y profesional. 


\begin{tabular}{|c|c|c|c|c|c|c|}
\hline DIMENSION & VARIABLE & 2004 & 2014 & UNIDAD & VARIACION & CRITICIDAD \\
\hline \multirow{6}{*}{$\begin{array}{l}\text { ORGANIZACIÓN } \\
\text { SOCIAL }\end{array}$} & Actividad comercial & $71 \%$ & $73 \%$ & porcentaje & $+3 \%$ & BAJA \\
\hline & Actividad recreativa & $2 \%$ & $3 \%$ & porcentaje & $+50 \%$ & ALTA \\
\hline & Densidad de población & 65 & 69 & hab/ha & $+6 \%$ & BAJA \\
\hline & $\begin{array}{l}\text { tamaño de hogar } \\
\text { predominante } \\
\text { (1 y } 2 \text { personas) }\end{array}$ & $58 \%$ & $68 \%$ & porcentaje & $+14 \%$ & MEDIA \\
\hline & $\begin{array}{l}\text { grupo etario } \\
\text { predominante } \\
\text { (20-39 años) }\end{array}$ & $33 \%$ & $38 \%$ & porcentaje & $+15 \%$ & MEDIA \\
\hline & $\begin{array}{l}\text { nivel educativo } \\
\text { predominante } \\
\text { (universitarios) }\end{array}$ & $40 \%$ & $49 \%$ & porcentaje & $+10 \%$ & MEDIA \\
\hline
\end{tabular}

Tabla 10. Comparación de variables de organización social de la zona sur. Fuente: Elaboración propia en base a trabajo de campo y datos censo INDEC (2001, 2010).

Respecto al cambio de perfil poblacional, el tipo de hogar predominante también varió, se incrementó la cantidad de hogares pequeños (de 1 y 2 personas), que pasan de representar el 58\% en 2004 al 68\% del total de los hogares del sector en 2014. Estos cambios tienen relación con las variaciones del tipo de vivienda predominante en la zona, particularmente con el incremento del tipo "departamento", que pasó de representar el 42\% de las viviendas en 2004 al 50\% en 2014, equiparándose a la tipología "casa" o vivienda unifamiliar.

En esta zona las transformaciones del paisaje urbano son más lentas, si bien se construyen edificios en altura que alteran la apariencia de las calles, la zona todavía conserva sus características barriales, así como también sus espacios públicos con una gran intensidad de uso, constituyendo elementos referenciales para los habitantes de dicha zona. No obstante, el cambio en la organización social, se comienza a visibilizar, con el cambio en las actividades y el perfil de población. 


\section{Dos etapas del proceso de densificación}

El análisis realizado para la zona norte y para la zona sur, seleccionadas como áreas testigo del proceso de densificación habitacional del área central de la ciudad de La Plata, pone en evidencia procesos de verticalización, que presentan efectos materiales muy diferentes y algunas similitudes. En términos de transformación del paisaje urbano, cada zona parece atravesar diferentes etapas del mismo proceso de densificación.

Por un lado, la zona norte sufrió una transformación abrupta del paisaje, el área se ha transformado de un barrio de casas bajas a una zona con muchos edificios en altura, en pocos años, reemplazaron viviendas unifamiliares, nuevas y antiguas, y de valor patrimonial. El parque edilicio se ha transformado notoriamente la cantidad de habitantes residentes y de parque automotor propio y de paso, también han crecido. Este proceso se ha dado de manera acelerada, con pérdida de patrimonio arquitectónico y urbano en la zona y un cambio en las prácticas urbanas cotidianas. Si comparamos con el periodo de diez años anterior la cantidad de edificios construidos se duplica. Esto ha generado que el tiempo de adaptación a los cambios se reduzca, y en lugar de adaptación al cambio, se reemplace la dinámica en el barrio. Las actividades nuevas se orientan a la nueva población que llega al barrio, así como el uso de los espacios públicos.

Por otro lado, en la zona sur, el proceso de verticalización fue más lento y mucho menos intenso, ya que mientras en la zona norte hubo un proceso de verticalización agresivo en cantidad, alturas y velocidad de la transformación material del espacio urbano, en la zona sur las transformaciones materiales pueden indicar apenas una etapa incipiente del proceso de verticalización edilicia. Por esto es que en el paisaje en la zona sur se conserva todavía cierta identidad ligada a tipologías de vivienda unifamiliares, con alturas de entre uno y dos niveles, a lo que se incorporan paulatinamente algunos edificios, manteniendo cierta continuidad paisajística en el tiempo. 
Dicha transformación del paisaje también se verifica en los aspectos patrimoniales y ambientales. En la zona norte el patrimonio arquitectónico disminuyó en un 20\% y la masa arbórea se redujo en un $14 \%$, mientras que en la zona sur las pérdidas fueron sólo del 4\%. En el Plano 1 se puede ver la coincidencia entre las edificaciones nuevas y los edificios con valor patrimonial demolidos en la zona norte. Los edificios en altura reemplazaron viviendas unifamiliares antiguas y no tan antiguas, cambiando la apariencia de las calles antes soleadas, hoy oscurecidas por la sombra que arrojan los edificios de hasta 10 niveles. Las edificaciones también afectan al arbolado público de manera directa, durante el periodo de construcción y post construcción debilitando raíces y copa de los árboles, e indirectamente cambiando el régimen de asoleamiento al que estaban adaptados.

No obstante, también se reconocen coincidencias entre las construcciones realizadas durante el periodo 2004-2014 en ambas zonas. Por un lado, al igual que se ve en los datos globales del área central, se constata una diferencia entre el incremento de construcción de viviendas y el incremento de población. Ambos sectores presentan mayor porcentaje de incremento de superficie construida ( $7 \%$ de incremento en la zona norte, $8 \%$ en la zona sur) que de incremento de densidad poblacional ( $3 \%$ de incremento de densidad en la zona norte y $6 \%$ en la zona sur). De la misma manera, se verifican comportamientos similares en cuanto a la variación del tamaño de hogar y la franja etaria mayoritaria residente en cada zona en el periodo en estudio. La variación que se registra en las dos variables, indica que, en el periodo de estudio, el efecto del proceso de densificación habitacional provocó un incremento, de población más joven y de hogares más pequeños en ambas zonas. La situación indica que, en el largo plazo, se perdería diversidad de población y hogares en el área central y que estos hogares se trasladarían hacia otros sectores, probablemente de la periferia.

Por otro lado, la distribución de las edificaciones en las zonas no guarda relación con el modelo de densificación por corredores principales que se plantea en el código de edificación. Como se puede ver el Plano 2 y Plano 4, la distribución de las edificaciones nuevas se aleja de los corredores, y comienzan a diseminarse por toda la zona, sin acentuar la verticalización sobre 
avenidas principales, que son las calles donde se concentran los recorridos del transporte colectivo, los comercios y servicios. La situación no contribuye a generar una sinergia entre densificación del área central y la reducción del uso de transporte privado.

Resulta de la comparación realizada que, tanto la composición como la disposición de la edificación transforman la configuración del espacio construido y tienen efectos que inciden sobre otras dimensiones de la la ciudad, transformando el paisaje de manera sistémica. Es decir, el incremento del parque habitacional como disparador del proceso, impulsa un recambio poblacional condicionado por el poder adquisitivo y el tamaño de las nuevas unidades funcionales. La nueva población atraída por estas nuevas condiciones urbanas de centralidad es joven y profesional.

Es probable que este perfil poblacional, por su composición de hogar unipersonal o de dos miembros, siendo profesional económicamente activo, tienda a desplegarse menos en el espacio público urbano, así como también tienda a participar menos de las actividades colectivas barriales. Se trata de jóvenes sin hijos, viviendo solos o en pareja, que suelen dedicar más horas al trabajo y deportes o hobbies, de menor impacto en el espacio colectivo de la ciudad.

Este perfil poblacional parece tener más oportunidades de consolidarse o generalizarse en la zona norte, tanto por la cantidad de departamentos pequeños vacantes como por la poca oferta de actividades colectivas que no son de predominante interés de este sector poblacional. Mientras tanto, en la zona sur, este perfil poblacional parece más tender a consolidarse como uno de los diversos grupos poblacionales de la zona, por efecto de la mixtura de tipos de población, tamaños de hogares y oferta de actividades colectivas muy consolidadas en la historia de estos barrios y con buena proyección. 
CAPITULO 6. La componente simbólica del paisaje 


\section{Lo simbólico, la identidad y la apropiación}

Complementariamente al estudio de las componentes materiales del paisaje, se desarrolla el estudio cualitativo y de mayor detalle, que busca conocer la percepción de los habitantes en relación a la transformación del paisaje urbano, indagando en la apropiación del espacio barrial mediante la valoración e identificación con la ciudad densificada. La apropiación espacial, en ámbitos urbanos, constituye un proceso simbólico que apela a una cierta identidad colectiva, grupal, de comunidad o de la sociedad, y a la acción (y transformación) en y hacia el barrio.

En este proceso los individuos se reconocen en el espacio colectivo a partir de elementos de referencia del paisaje, que actúan como símbolos que contienen y transmiten significados y códigos culturales. Estos son procesos simbólicos que se evidencian a partir de una cierta identificación, valoración, significación y en el reconocimiento de un área como una unidad con identidad propia; sea barrial, social o paisajística.

El estudio cualitativo se realizó en las dos zonas, Norte y Sur, a fin de detectar las diferencias y similitudes en cada caso, acerca de la percepción de los habitantes y vincularlo con el grado de transformación material del paisaje, previamente analizado. El estudio se realizó mediante entrevistas semiestructuradas, organizadas en torno a tres temas: i) Identificación con el barrio, ii) valoración y significado del paisaje y iii) acción y transformación del barrio.

Para caracterizar (i) la identificación de los habitantes con el barrio, se indagó en el reconocimiento de identidad o nombre de su barrio, en el reconocimiento de los límites de ese mismo barrio que habitan, y la caracterización del paisaje urbano. Para dar cuenta de la percepción de los habitantes respecto de la (ii) valoración y significado del paisaje, se indagó en el reconocimiento del estado de la zona, la valoración del paisaje del espacio residencial densificado y en la valoración del paisaje del espacio público. Para investigar (iii) La 
transformación del barrio, se investigaron las acciones orientadas al barrio a través del registro de las actividades que los habitantes realizan dentro del barrio, el registro de la apropiación de espacios colectivos y las actividades colectivas vecinales.

\section{Percepción de la componente simbólica en la zona norte}

En relación a la identificación de los habitantes con el barrio (I), los resultados del estudio en la zona norte evidencian en general una cierta ausencia de identificación colectiva o pertenencia grupal a los sectores que la componen. A juzgar por las respuestas obtenidas, es posible afirmar que no existe un barrio concreto al cual apelar, dado que no se reconoce una percepción de unidad barrial en los relatos de los entrevistados.

Al preguntar si el lugar donde vive forma parte de un barrio, más de la mitad de los entrevistados dijo no reconocer un nombre de barrio propio ni asociado a alguno de sus espacios públicos. Los restantes entrevistados reconocieron la zona como de interfase entre dos barrios más tradicionales o como parte del centro de la ciudad. En general, los entrevistados tampoco reconocieron los límites o alcances de su barrio de forma clara, es decir, no se reconoce una unidad barrial con la cual identificarse. Al analizar las respuestas, tanto afirmativas como negativas, no se encuentra correlación entre la cantidad de años de residencia de los habitantes en la zona y el reconocimiento de identidad barrial, es decir que, el tiempo no resulta determinante en este caso. 


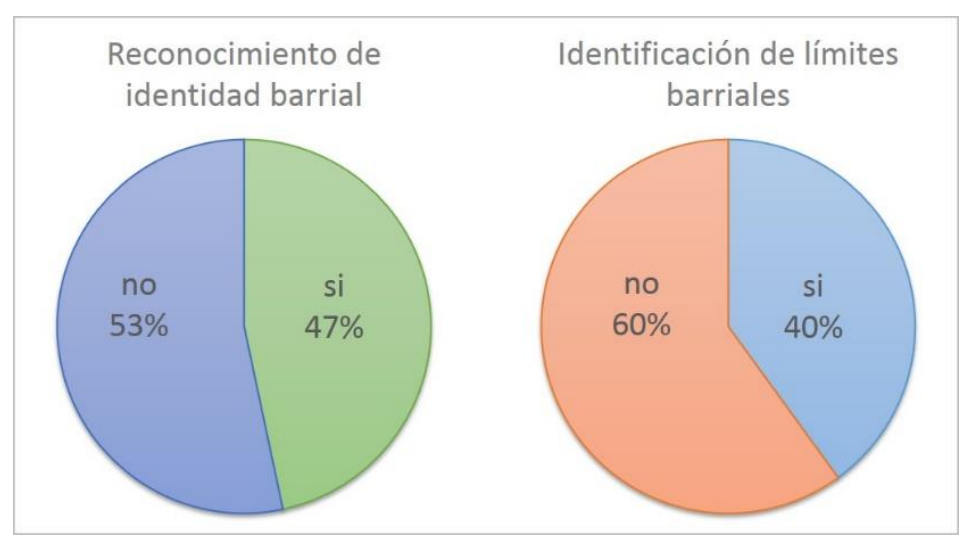

Gráfico 1. Reconocimiento de Identidad y límites del barrio en la zona norte. Fuente: Elaboración propia en base a entrevistas semiestructurada 2019.

Referente a la caracterización del paisaje barrial, se le preguntó cómo describiría el paisaje urbano del barrio o la zona donde vive y qué elementos destaca como significativos, a fin de detectar elementos que puedan dar cierta unidad al paisaje. Las respuestas se pueden agrupar en cinco paquetes temáticos, que se asocian a elementos de referencia del paisaje. (Ver Gráfico 2) En primer lugar, se destacó al paisaje como un paisaje cambiante, en constante transformación, vinculado a la construcción de edificios en altura. En segundo lugar, se describió como un paisaje caótico, vinculado al intenso tránsito vehicular y la sobrecarga de autos estacionados. En tercer lugar, se describió al paisaje como agradable, vinculado al cuidado y limpieza de la zona. Por último, y en igual proporción, se describió como un paisaje tranquilo y verde, en relación refiriendo a la presencia de espacios verdes y la calidad de la zona.

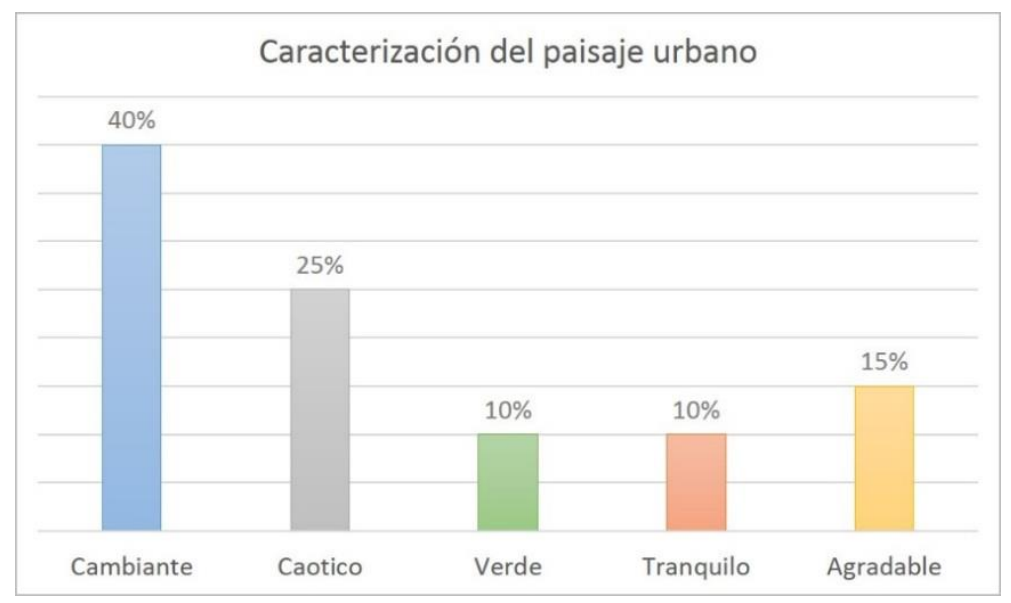

Gráfico 2. Palabras que utilizan para descripción el paisaje los entrevistados de la zona norte. Fuente: Elaboración propia en base a entrevistas semiestructurada

2019. 
Los resultados de la caracterización del paisaje de la zona norte indican que, a pesar de que más de la mitad de los entrevistados lo describió de forma negativa, todos los entrevistados declararon estar contentos de vivir en el barrio, destacando, como principal atractivo, la accesibilidad al centro. Paradójicamente, dicha ventaja es la contracara del tránsito caótico y ruidoso, que es la principal crítica expuesta por los entrevistados:

Investigador: ¿Está contento de vivir ahí ¿Por qué?

Entrevistado: "Si, me gusta vivir en este barrio. Es dentro de todo más tranquilo que el centro y tiene buena accesibilidad y está cerca de todo." Entrevistada $n^{\circ} \mathrm{N} 15$, comunicación personal, 3 de septiembre 2018

Con relación a la valoración y significado del paisaje en esta zona (II), la mayoría de los entrevistados expresaron que el estado del barrio ha empeorado y lo relacionaron a la construcción de nuevos edificios con efectos sobre los temas de infraestructura. Por un lado, el incremento de viviendas y población afecta a la capacidad de los servicios de agua, cloaca, luz y gas, ya que al tener mayor demanda comienzan a tener problemas en la distribución. Por otro lado, mayor población incrementa las tasas de motorización en la zona, con lo cual aumenta el tránsito en la zona y escasea el espacio de estacionamiento.

Investigador: ¿Cómo cree que está hoy la zona en la que usted vive, mejor/ igual/ peor que hace unos años atrás?

Entrevistado: "Peor en cuanto al crecimiento de edificios. En 3 años se hicieron muchos nuevos edificios y los servicios son los mismos que antes. Hay mucho tránsito. Mejor en cuanto a la actividad, muchos comercios, se puede hacer todo en el barrio sin tener que ir al centro." Entrevistada $n^{\circ}$ N15, comunicación personal, 3 de septiembre 2018.

Investigador: ¿Cómo cree que está hoy la zona en la que usted vive, mejor/ igual/ peor que hace unos años atrás?

Entrevistado: "mejor en cuanto al crecimiento del barrio, y hay más servicios, peor porque es más inseguro, hay mucho tránsito y no hay estacionamiento." Entrevistada $n^{\circ}$ N12, comunicación personal, 2 de septiembre 2018.

En respuesta a la misma pregunta una minoría señaló que el barrio está igual, y solo 2 entrevistados dijeron que la zona está mejor. Estos últimos, relacionaron la mejora del barrio con 
el incremento de los comercios y la posibilidad de resolver las actividades sin desplazarse grandes distancias. En este caso se puede establecer una relación entre una mayor antigüedad de residencia y una valoración negativa de las transformaciones paisajísticas, ya que son los residentes con mayor cantidad de años en la zona, los que pueden establecer comparaciones con momentos previos al inicio del proceso de verticalización.

Para al reconocimiento y valoración del paisaje se preguntó por dos tipos de paisaje, a partir de la presentación de fotografías de esta zona, una escena urbana con densificación habitacional y otra con espacios públicos propios de la zona.

Al valorar el paisaje del espacio privado densificado la mayoría de los entrevistados consideró al paisaje, por un lado, como algo cuidado, algo seguro y algo tranquilo, y por el otro, indicó que estos paisajes son insignificantes o desagradables. Es decir, los entrevistados destacan al paisaje densificado como positivo en un sentido funcional, pero no en términos de valoración simbólica.

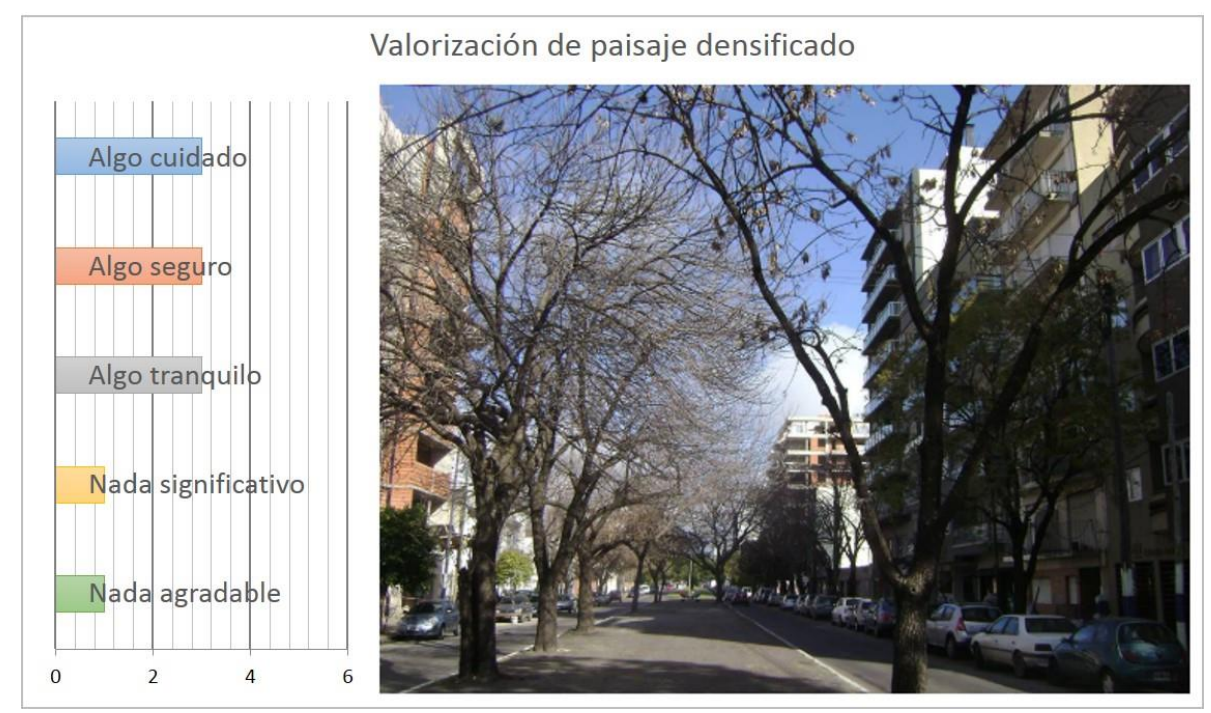

Gráfico 3. Reconocimiento y valoración del paisaje del espacio privado densificado en la zona norte. Fuente: Elaboración propia en base a entrevistas semiestructurada y fotografías del autor 2019.

En el caso de la valoración del paisaje del espacio público, la mayoría de los entrevistados consideró al paisaje de manera positiva. Por un lado, se valoró como muy cuidado, muy tranquilo y algo seguro, y por el otro, se indicó que estos paisajes son bastante significativos y muy 
agradables, es decir que presenta elementos simbólicos y estéticos valorados por los entrevistados.

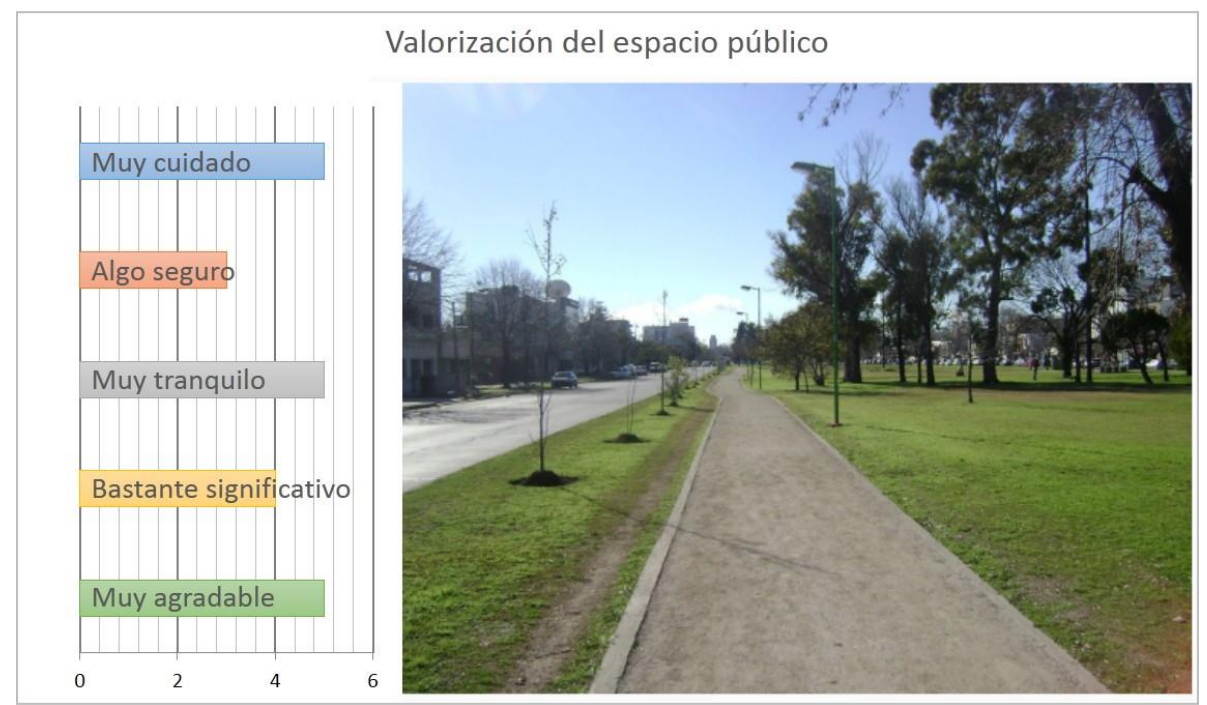

Gráfico 4. Reconocimiento y valoración del paisaje del espacio público zona norte. Fuente: Elaboración propia en base a entrevistas semiestructurada y fotografías del autor 2019.

Sobre la transformación del barrio (III), hay una generalizada percepción de la transformación material ligada al proceso de densificación y verticalización en esta zona. El estudio detectó en los relatos, el impacto de la actividad de la construcción como principal percepción de cambio por parte de los habitantes. Todos los entrevistados señalaron que hay más edificios y más altos, casi la totalidad de los entrevistados reconoció que hay nuevos vecinos en el barrio, y una gran mayoría percibió que hubo un incremento de las actividades comerciales, principalmente. Asimismo, los entrevistados resaltaron la presión que ejerce la actividad inmobiliaria en la venta de viviendas unifamiliares tradicionales, que luego son convertidas en edificios en altura, lo que resulta de gran incomodidad a quienes continúan viviendo rodeados de edificios en altura.

Sobre las acciones orientadas al barrio, que exponen el vínculo del individuo (y también los grupos sociales) con el espacio barrial, los entrevistados declararon en su mayoría realizar las actividades cotidianas dentro del barrio. Esto podría evidenciar que la zona tiene comercios y servicios que pueden abastecer el consumo diario. 


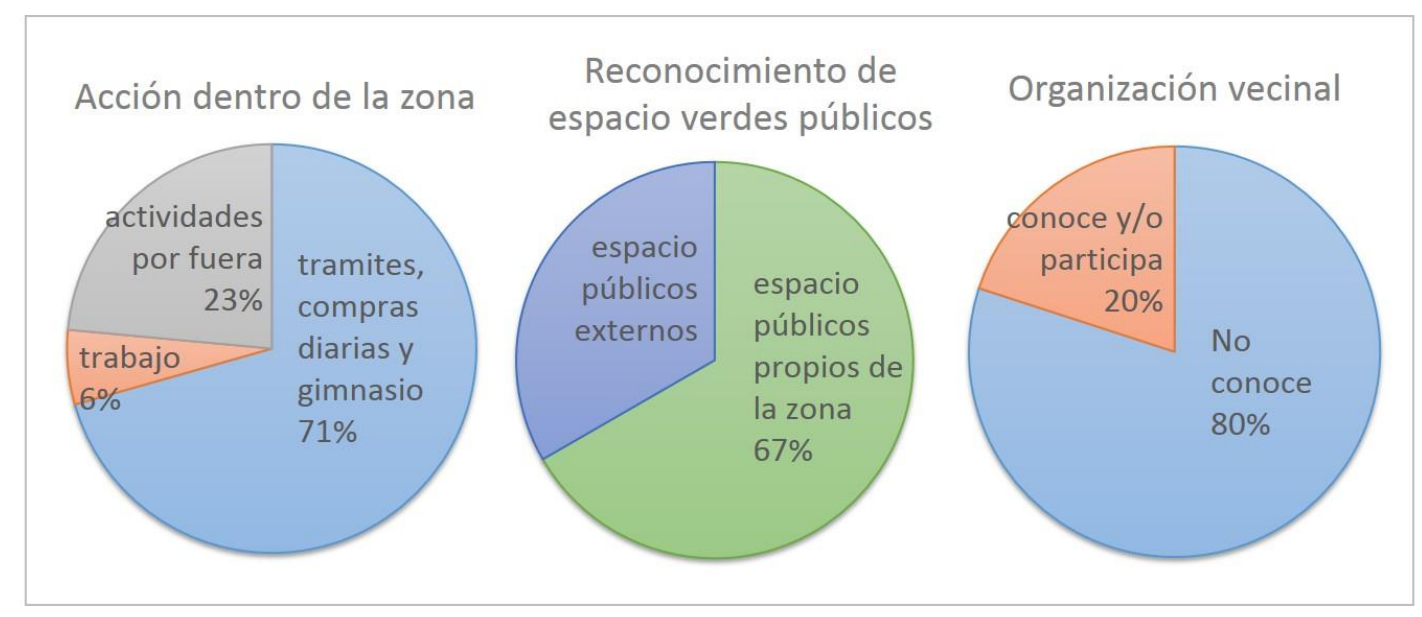

Gráfico 5. Apropiación de espacios colectivos y actividades del barrio, zona norte. Fuente: Elaboración propia en base a entrevistas semiestructurada 2019.

Con relación a la apropiación de los espacios colectivos dentro del sector, los resultados indican que los residentes guardan escasa relación con éstos. En este sentido cabe destacar que, si bien la totalidad de los entrevistados reconoció la existencia de espacios públicos en el sector, la tercera parte de ellos identificó veredas, plazas y parques externos al barrio, lo que visibiliza que los espacios verdes públicos apropiados por los entrevistados estarían por fuera del área de la zona norte.

Respecto a las actividades colectivas vecinales, los resultados muestran una tendencia de la zona a las actividades urbanas más individuales. Los resultados del estudio indican que los vínculos entre vecinos son muy escasos, siendo una minoría de los entrevistados quienes reconocen la existencia de algún tipo de organización vecinal o tiene participación en alguna de ellas, lo que sugiere cierto déficit de organización social en la zona. Estas respuestas son convergentes con las observaciones realizadas en el espacio público, restringido predominantemente a prácticas urbanas cotidianas individuales, con ausencia de iniciativas colectivas, que permitan construir y compartir códigos culturales en común.

En síntesis, la dimensión simbólica del paisaje densificado de la zona norte da indicios de pérdida y fractura, visibles en la falta de identificación de los habitantes con el barrio, en el escaso reconocimiento de identidad o nombre del barrio y en la falta de reconocimiento de los límites de ese mismo barrio que habitan. La percepción recogida de los habitantes respecto de la valoración 
del barrio, no es negativa, pero hace hincapié en aspectos espaciales y estéticos no vinculados al despliegue de la pertenencia social y colectiva de los habitantes con el barrio. En este sentido, se destacan aspectos de la seguridad y tranquilidad, ligadas a las prácticas urbanas más individuales. La percepción general a la transformación del barrio, es negativa, haciendo hincapié en la pérdida de calidad urbana producto del incremento de edificaciones en altura. En relación a las acciones orientadas al barrio, no se evidencia el uso y participación en los espacios y actividades colectivas, solo se destaca la actividad individual en los servicios y comercios de la zona.

\section{Percepción de la componente simbólica en la zona sur}

En cuanto a la identificación de los habitantes con el barrio (I), los resultados del estudio en la zona sur evidencian una situación bien diferenciada respecto de los hallados en la zona norte. El estudio permite dar cuenta de una identificación colectiva o pertenencia grupal con los barrios que componen la zona. A juzgar por las respuestas obtenidas, es posible afirmar que, no solamente existen barrios colectivamente reconocidos y que llevan los nombres de los espacios públicos de uso colectivo que los conforman, sino que además se reconoce una percepción de unidad barrial en los relatos de los entrevistados.

Al preguntar si el lugar donde vive forma parte de un barrio, la mayoría de los entrevistados de la zona sur reconoció el nombre de los barrios que habitan. Igualmente, reconocieron que el corredor de Av. 13 que atraviesa el sector provoca una divisoria de la zona separando en dos barrios: Barrio Meridiano V hacia el sur, y Barrio Parque Saavedra hacia el norte.

En este caso, el peso del tiempo influye en la construcción de identidad de barrio y en el reconocimiento que pueden hacer los habitantes residentes en la definición de límites barriales, acorde al tiempo de residencia de los entrevistados. Es decir que hay una coincidencia entre las 
respuestas con afirmaciones más contundentes y con más detalles y la mayor cantidad de años de residencia en la zona, que alcanza los 74 años en el caso del entrevistado con más antigüedad.

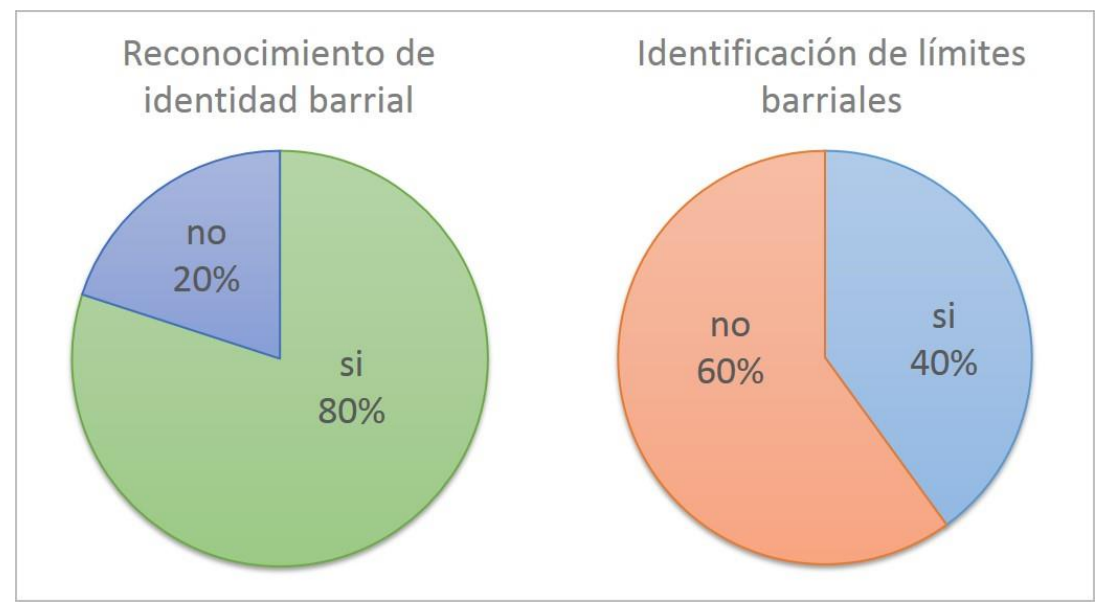

\section{Gráfico 6. Reconocimiento de Identidad y límites del Barrio en la zona sur. Fuente:} Elaboración propia en base a entrevistas semiestructurada 2019.

Para los habitantes del barrio Meridiano $V$, la antigua estación del tren provincial que le dio su nombre, junto al club barrial del mismo nombre, componen la identidad y el imaginario del barrio. Los entrevistados residentes dentro del barrio Parque Saavedra no se consideran participantes de un barrio constituido, a pesar de que reconocen el parque, su adoquinado y el Hospital de Niños, como elementos de identidad barrial. Si bien no se desprende de las entrevistas la posibilidad de establecer los límites de cada barrio y de hecho los límites no se perciben claramente, sí es posible distinguir con certeza cuales son aquellos elementos e hitos urbanos que componen la identidad barrial de cada uno.

En cuanto a la caracterización del paisaje urbano, los temas clave que aparecen en las entrevistas son claramente diferentes de los que se dan en la zona norte. Las respuestas se pueden agrupar en cuatro paquetes temáticos, donde particularmente el 'verde' como tema, presenta una notable preponderancia en las respuestas de los entrevistados de esta zona. En torno a este tema clave, se describe un paisaje verde, ligado a la fuerte presencia de arbolado y espacios verdes públicos. En segundo lugar, se destaca el tema de un paisaje histórico, vinculado al patrimonio arquitectónico y cultural presente en la zona. En tercer lugar, se describe al paisaje como tradicional, en relación 
a que los vecinos se mantienen en la zona y se conocen entre ellos. Por último, se describe el paisaje como cambiante, vinculado a la construcción de edificios en altura. Los temas mencionados pueden reconocerse en elementos de referencia que componen el paisaje de la zona sur.

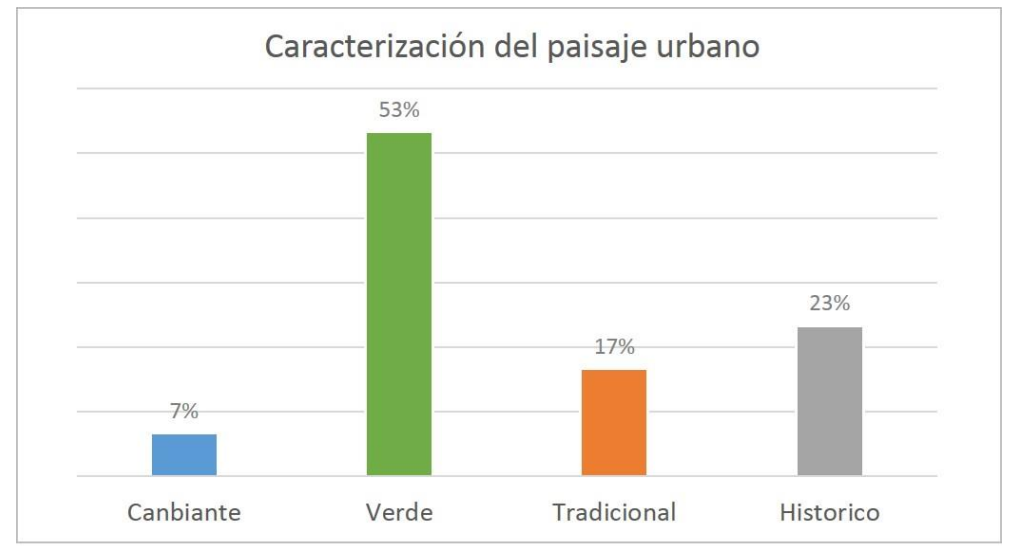

Gráfico 7. Palabras que utilizan para descripción el paisaje los entrevistados de la zona sur. Fuente: Elaboración propia en base a entrevistas semi-estructurada

2019.

Los resultados de la caracterización del paisaje de la zona sur indican que, casi la totalidad de los entrevistados está contenta de vivir en la zona, y más de la mitad volvería a elegir la zona como residencia. Las razones que expresan aluden a los temas con los que describen el paisaje, la tranquilidad, los espacios verdes, la accesibilidad y las actividades dentro de la zona.

Investigador: ¿Está contento de vivir ahi? ¿Por qué?

Entrevistado: "Si, muy contenta porque aqui tengo todo lo necesario desde los comercios como lugares de esparcimiento, con calles amplias, arboladas, escuelas, el hospital de niños. Me encanta mi barrio." Entrevistada $n{ }^{\circ} S 6$, comunicación personal, 25 de abril 2018

En cuanto a la valoración y significado del paisaje en esta zona (II) valoración del estado de la zona, la mitad de los entrevistados expresaron que el estado del barrio es mejor y lo relacionaron a la infraestructura y el incremento de comercios principalmente gastronómicos. También, se expresaron de manera muy positiva con la presencia de actividades culturales en la zona, como por ejemplo las actividades autogestionadas en el Parque Saavedra y el Centro Cultural Meridiano V. Del resto de los entrevistados, más de la mitad señala que el barrio está igual, y una minoría 
dice que la zona está peor, vinculado a la construcción de edificios en altura y la pérdida de patrimonio arquitectónico. El tiempo no resulta determinante en este caso, si analizamos las respuestas, tanto afirmativas como negativas, no se encuentra correlación entre cantidad de años de residencia en la zona y la valoración del estado del paisaje.

Investigador: ¿Cómo cree que está hoy la zona en la que usted vive, mejor/ igual/ peor que hace unos años atrás?

Entrevistado: "Similar, mejor en la cantidad de locales y servicios que ofrece el barrio, pero más atareado por los edificios y cantidad de habitantes."

Entrevistada $n^{\circ}$ S4, comunicación personal, 25 de abril 2018

En cuanto a la valoración del paisaje del espacio privado densificado, a partir de la presentación de fotografías de esta zona, los entrevistados valoraron este paisaje como algo tranquilo y significativo, pero como poco seguro, poco agradable y nada cuidado. En este caso, la imagen muestra la gran presencia de verde en la zona, que es uno de los elementos destacados por los habitantes, y al mismo tiempo la irrupción de los edificios en altura, destacado como elemento negativo en el paisaje.

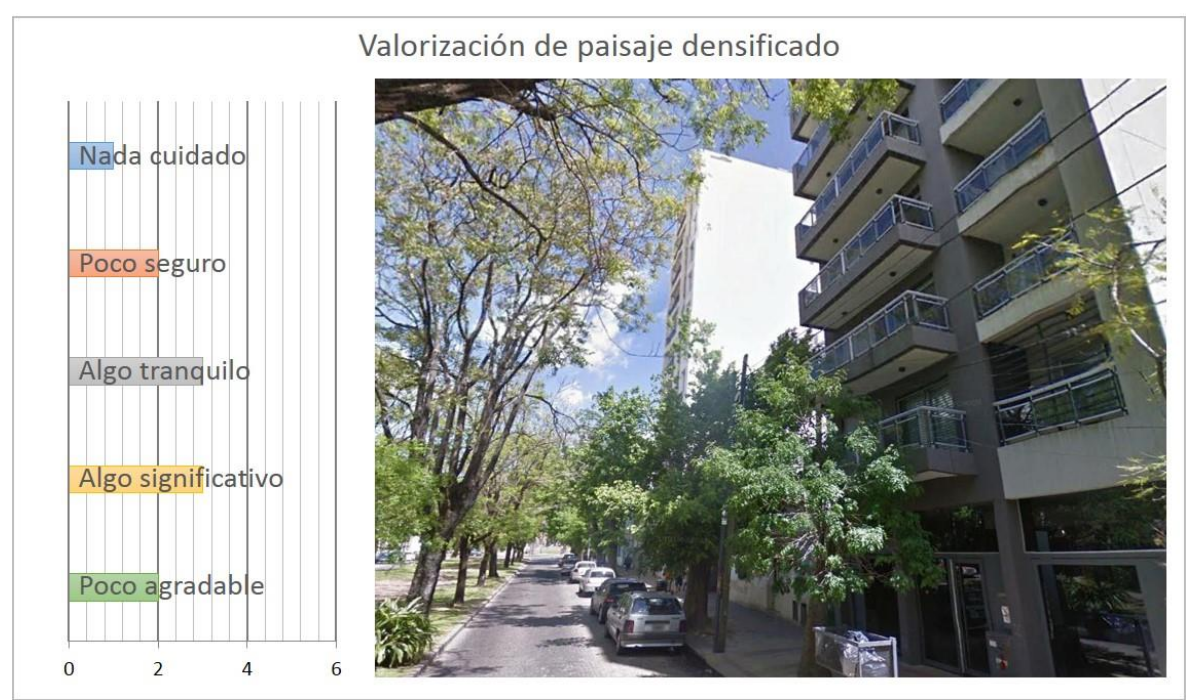

Gráfico 8. Reconocimiento y valoración del paisaje del espacio privado densificado zona sur. Fuente: Elaboración propia en base a entrevistas semiestructurada y fotografías del autor 2019.

En cuanto a la valoración del paisaje del espacio público, la presencia de arbolado en todas las imágenes urbanas es muy valorada. En el caso del Parque Saavedra, la presencia de la feria y la 
forestación es valorada como bastante agradable y significativa, respecto a la funcionalidad resulta algo tranquilo y algo cuidado, pero poco seguro.

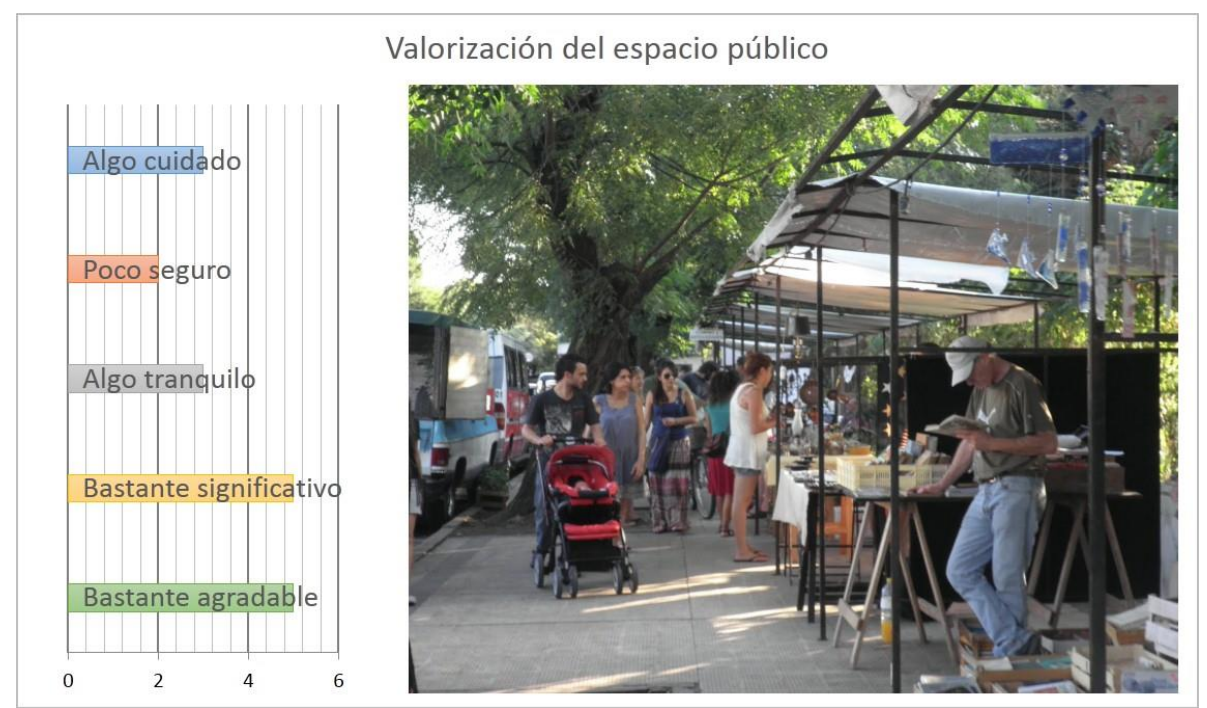

Gráfico 9. Reconocimiento y valoración del paisaje del espacio público zona sur. Fuente: Elaboración propia en base a entrevistas semiestructurada y Fotografías de la autora 2019.

En relación a la transformación del barrio (III), se verifica una generalizada percepción de la transformación material ligada al proceso de crecimiento del parque habitacional y de la población en ambos barrios que componen la zona sur. A través de los resultados del estudio se detectó en los relatos, la percepción de cambios en la zona, no solamente de nueva población sino además de aparición de nuevos edificios en altura y nueva actividad. La mayoría de los entrevistados reconoció que hay nuevos edificios en la zona, y casi todos percibieron que hubo un incremento de las actividades comerciales, principalmente relacionadas con la gastronomía, y más de la mitad señaló que hay nuevos vecinos en el sector. Los entrevistados del Barrio Parque Saavedra son los que reconocen, en mayor medida, la presión que ejerce la actividad inmobiliaria en la zona.

Investigador: ¿Desde que usted está viviendo en este lugar, aumentó la población residente?

Entrevistado: Si aumentó. Tengo los mismos vecinos y algunos nuevos por la cantidad de edificios que han hecho. Entrevistada $n^{\circ}$ S6, comunicación personal, 25 de abril 2018. 
En lo que se refiere a las acciones orientadas al barrio, que exponen el vínculo del individuo (y también de los grupos sociales) con el espacio barrial, los entrevistados declararon en su mayoría realizar las actividades cotidianas dentro del barrio. Esto podría evidenciar que la zona tiene comercios y servicios que pueden abastecer el consumo diario. Y en relación a la apropiación de los espacios colectivos dentro de la zona, los resultados indican que los residentes tienen gran relación con estos espacios. Casi la totalidad de los entrevistados reconoció la existencia de espacios verdes públicos en el sector, y la mayoría identificó los nombres y reconoció que los usan cotidianamente. En este sector se da un fenómeno particular, que es la autogestión vecinal para desarrollar actividades y rehabilitar espacios públicos.

Se destacan, en este sentido, La Biblioteca "Del otro lado del árbol" en el Parque Saavedra, la estación de calle 12 y 72, la Feria Artesanal del Parque, desprendimiento de los clubes de trueque iniciados en la crisis de 2001. Estas iniciativas son ejemplo de cómo la gente se organiza y encuentra en estos espacios públicos el lugar para sus actividades colectivas y lo hace propio, invirtiendo tiempo, esfuerzo y recursos en mejorarlo, acondicionarlo y mantenerlo.

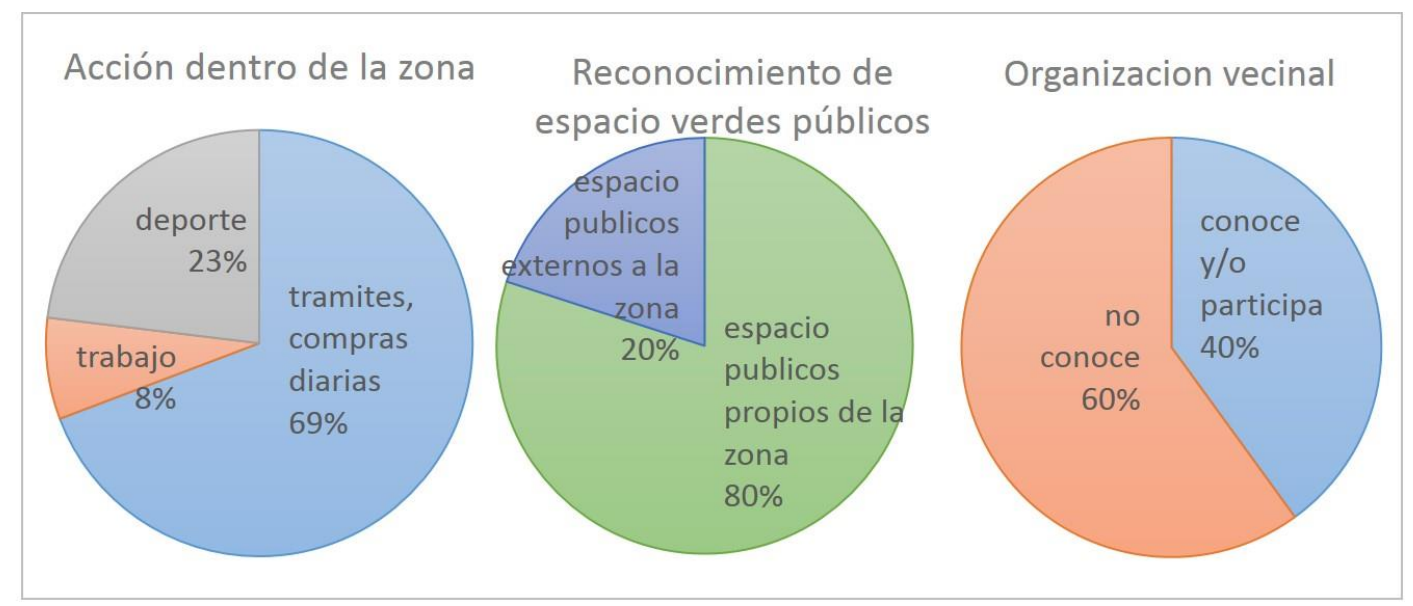

Gráfico 10. Apropiación de espacios colectivos y actividades del barrio, zona sur. Fuente: Elaboración propia en base a entrevistas semiestructurada 2019.

En relación a las actividades colectivas vecinales, los resultados muestran la permanencia de este tipo de actividades colectivas en la zona. Los resultados del estudio indican que hay vínculos 
entre vecinos, siendo un poco menos de la mitad de los entrevistados, quienes reconocen la existencia de algún tipo de organización vecinal o tiene participación en alguna de ellas, lo que refleja una mayor organización barrial, respecto de la zona norte. Estas respuestas son convergentes con las observaciones realizadas en el espacio público, con fuerte presencia de actividad y prácticas urbanas colectivas, que permiten construir y compartir códigos culturales en común en esta zona.

En síntesis, la dimensión simbólica del paisaje densificado de la zona sur da indicios de una apropiación del espacio barrial, evidenciado en la identificación de los habitantes con los espacios colectivos y en el reconocimiento de identidad barrial. La percepción recogida de los habitantes respecto de la valoración del barrio, es positiva, haciendo hincapié en la pertenencia social y colectiva de los habitantes con el barrio, se destacan aspectos de agrado y significación, ligadas al valor patrimonial y estético de las componentes del paisaje. Respecto la transformación del barrio, si bien la pérdida de calidad urbana producto del incremento de edificaciones en altura se reconoce como un proceso incipiente y perjudicial para la zona, la percepción general es positiva, haciendo hincapié en los procesos de recuperación de los espacios públicos. Las acciones orientadas al barrio evidencian una alta participación en los espacios y actividades colectivas, y se destaca que los elementos referenciales en la zona están relacionados con el espacio público.

\section{Dos procesos de apropiación en áreas centrales}

Si comparamos las componentes simbólicas de ambas zonas vemos que, así como la transformación material del paisaje presenta diferencias y similitudes en las zonas estudiadas, también hay discrepancias y coincidencias en cuanto a percepción y valoración del paisaje entre los relatos de los habitantes de ambas zonas. 
En términos generales, la zona norte es percibida como un área no muy definida, constituida por la continuidad de un tejido urbano consolidado y denso, con buena accesibilidad, pero desprovista de ciertas componentes simbólicas, de identidad y pertenencia barrial. En esta zona, los procesos de transformación material que modifican el subsistema construido y producen la verticalización edilicia y el recambio de población, se perciben por parte de los residentes, como procesos invasivos y negativos. Los entrevistados ponen en valor ciertas características de estética y seguridad de la zona, pero, sin embargo, reconocen más procesos y factores negativos que positivos en ese paisaje.

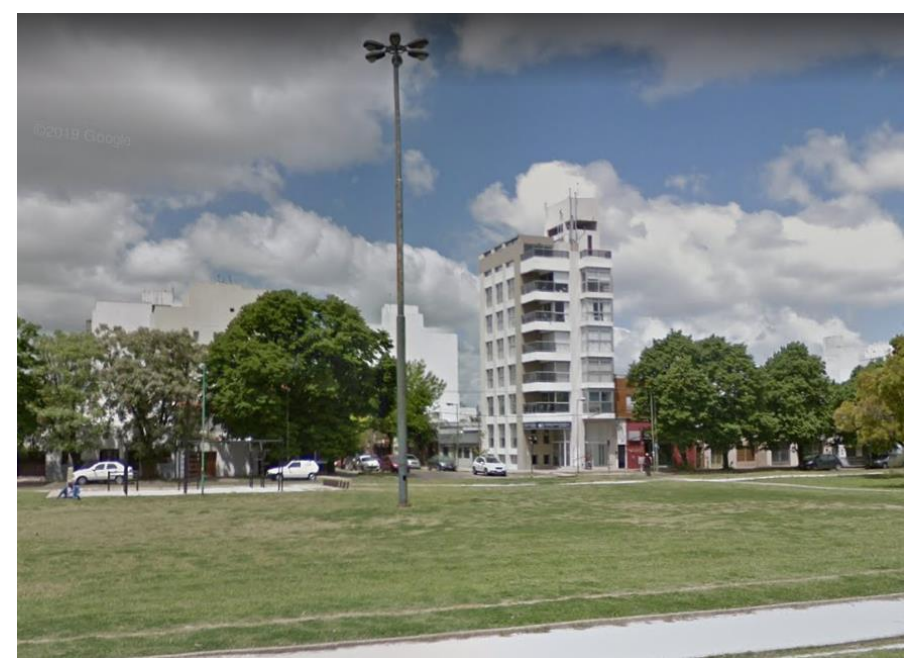

Imagen 18. Rambla de avenida circunvalación. Fotografías de la autora 2014

En contraposición, la zona sur es percibida de manera predominantemente positiva. En las respuestas de los entrevistados se pueden distinguir las distintas y unívocas identidades barriales, ligadas a lugares y a actividades. Se reconocen asimismo los dos sectores barriales que componen la zona, diferenciados por nombre. De los relatos de los entrevistados se registra una importante carga de elementos simbólicos que permiten referenciar, espacial y temporalmente, procesos y actividades colectivas. Estos tienen mayor preponderancia en la percepción del paisaje de la zona, que los procesos de verticalización iniciados en el sector. Los temas valorados de la zona son los espacios verdes públicos, la identidad de cada barrio, la calidad paisajista y la tranquilidad, y como temas conflictivos se destacan el incremento de tránsito, el ruido y la inseguridad. 


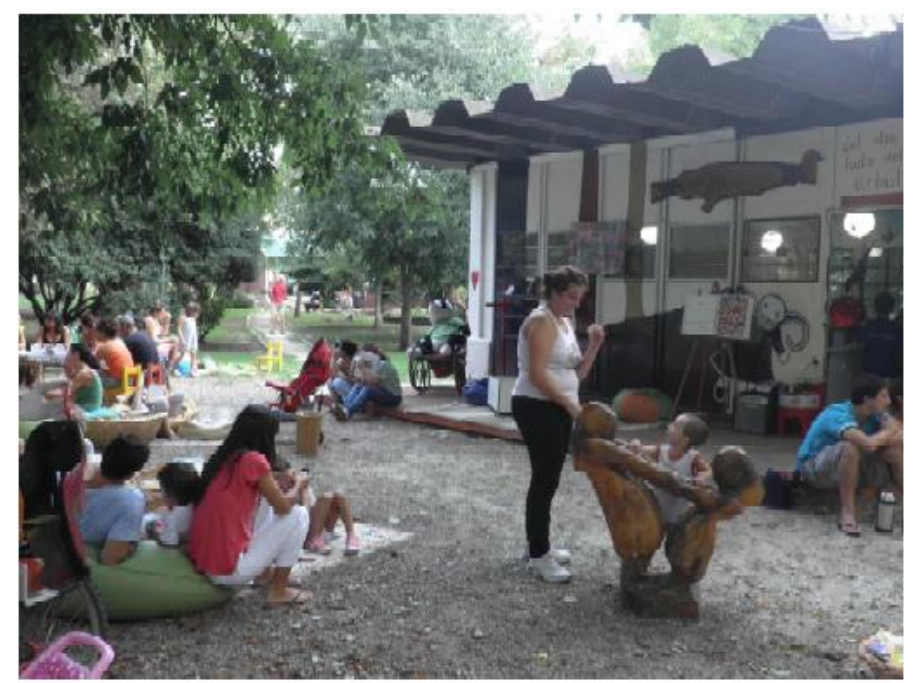

Imagen 19. Biblioteca “del otro lado" Parque Saavedra. Fotografía de la autora 2012.

Una de las discrepancias encontradas está en relación a la identificación de los habitantes con el barrio. Si bien en ambas zonas la percepción de límites de los barrios es casi nula, la percepción de identidad se comporta de manera diferente. Casi la totalidad de los entrevistados en la zona sur reconoce su identidad barrial, mientras que en la zona norte menos de la mitad de los entrevistados logra identificarla. En la zona sur las identidades barriales están ligadas a los hitos urbanos existentes, el Parque Saavedra y la Estación Meridiano V. En contraposición, en la zona norte, la homogeneidad del tejido urbano y la menor cantidad e impacto de los hitos urbanos, no permite ligar el espacio barrial con algún elemento de referencia que aporte identidad a la zona.

A cerca de la percepción de transformación, hay similitud en las percepciones, en ambos sectores se declaró que el paisaje ha cambiado. Sin embargo, la valoración de los cambios es diametralmente opuesta, en la zona norte la mayoría expresa que la zona está peor que antes, mientras que en la zona sur casi la totalidad señala que la zona está mejor que antes. Si confrontamos estas respuestas con los grupos de temas que surgen de la caracterización del paisaje en cada sector, podemos identificar los elementos clave en la valoración del paisaje del área central de La Plata. Los procesos continuos de transformación y el caos, vinculado al incremento de construcción, personas y automóviles circulando, son factores negativos que aparecen fuertemente en la zona norte y que aparecen con debilidad en la zona sur. Los espacios verdes y 
el capital cultural, acumulado y plasmado en patrimonio arquitectónico y urbano, son factores positivos que aparecen en la zona sur y que no se perciben de igual manera en la zona norte.

A partir de esta comparación se reconoce que, la transformación material dispar genera a su vez, efectos sociales diferenciados, consolidando diversas formas de relación de las personas con su barrio. De esta manera, el despliegue de vínculos de pertenencia de la población con el lugar orienta formas de crecimiento y desarrollo urbano-ambiental más sustentable. Mientras que el proceso de densificación con transformaciones bruscas del paisaje desencadena la pérdida de referencia de la población con su hábitat. En estas afirmaciones las condiciones materiales prexistentes en cada caso son muy relevantes, ya que las proporciones de espacio público potencialmente apropiable para cada zona, eran similares en tiempos de la fundación de la ciudad, pero tenían desventajas en la zona norte, al inicio del periodo de estudio.

Esta disponibilidad de espacios públicos, ya sean parques, plazas, ramblas o edificios de uso colectivo como generadores de oportunidades de actividades colectivas y condensadores de significados históricos compartidos, cobra mayor relevancia en contextos de tejido urbano en proceso de consolidación. En efecto la zona norte, como se ha señalado, viene siendo presionada por el mercado inmobiliario desde mediados del siglo XX por su mayor proximidad a ciudad de Buenos Aires como gran atractor laboral y productivo. Es en ese proceso que los espacios públicos pierden jerarquía y valor como atributo del paisaje en la zona y los procesos de apropiación espacial comienzan a declinar. Para la zona sur este proceso de densificación reciente, constituye una posibilidad material de consolidar su tejido urbano, condicionado por las restricciones propias que ofrecen los territorios cuyos procesos urbano-sociales son intensos y están arraigados y muy consolidados en el espacio público, tal como sucede en la zona sur. En este caso el proceso de verticalización acompaña el proceso de apropiación espacial, rescatando los elementos del paisaje valorados: la presencia de vegetación, espacios verdes y la actividad cultural, como estrategia de marketing para la venta de los inmuebles. 
CAPITULO 7. Análisis de resultados 


\section{Componentes del paisaje y sus relaciones}

A partir del estudio y análisis de los datos cuantitativos y de las entrevistas registradas y comparadas, se ponen en evidencia no solamente las componentes del paisaje urbano que entran en juego en los procesos de densificación y verticalización urbana, sino también, las relaciones directas e indirectas que se despliegan entre sus componentes materiales y simbólicos. Si bien el proceso de densificación mediante la verticalización edilicia es un proceso que afecta directamente a la configuración del espacio privado construido, el fenómeno se transforma en problema a partir de reconocer los impactos derivados de la dimensión de la configuración del espacio público y la organización social, que a su vez inciden en las dimensiones simbólicas de identificación, valoración, significado y transformación del barrio, que componen el paisaje urbano y cuando estos efectos contradicen los objetivos del proceso de densificación que les dio origen.

Como se ha señalado el modelo de crecimiento compacto, como alternativa al crecimiento periférico extensivo, requiere aumentar las densidades de ocupación aprovechando la disponibilidad de infraestructura y servicios subutilizados en las centralidades. Sin embargo, si el proceso de verticalización genera una sobrecarga en la capacidad de estacionamientos, un reemplazo de los servicios disponibles, una reducción de la oferta de espacios verdes público o un recambio poblacional con desplazamientos, como se pudo verificar en el caso de la zona norte del área central de la ciudad, los resultados obtenidos por el proceso producido claramente son los esperados.

En este sentido, en el proceso de verticalización edilicia en el área central de La Plata se detectan dos núcleos problemáticos que estructuran el análisis. Por un lado, las transformaciones del espacio construido no se limitan a un cambio de forma, sino que el cambio de tipología edilicia 
transforma las viviendas y condiciona el perfil de población que puede habitar la zona, lo que incide en la transformación de la manera de usar este espacio urbano. Por otro lado, al transformar el espacio construido se cambia también la apariencia y dinámica del espacio público, incidiendo en la manera de percibir y valorar el paisaje urbano.

Estos procesos, propios de las transformaciones urbanas en áreas centrales, alteran las características materiales y los códigos y pautas simbólicas del paisaje consolidadas a lo largo de los años. De esta manera, se cambian las condiciones en las que los habitantes del área central habían iniciado los procesos de apropiación espacial, quebrando los procesos y obligando a los habitantes a establecer otros códigos y relaciones con el paisaje.

\section{Morfología y tipología en el espacio construido}

La principal transformación en el paisaje, producto del proceso de verticalización analizado, se produce en el aspecto morfológico de la configuración del espacio construido, ya que en este tipo de proceso la altura de edificación es la variable en juego más evidente. Si bien hay muchas edificaciones con alturas diversas, producto de la construcción histórica del paisaje del área central de la ciudad y de la superposición de normativas que regulan la construcción, lo destacable en el periodo analizado es que la altura predominante aumentó a más del doble en un periodo de diez años. Dicho incremento cambia por completo la percepción del paisaje urbano, a partir del cambio en la relación de luz y sombra y la relación con el arbolado público. Es decir que la forma que tomó el espacio construido impactó a la escala humana y urbana más allá de cómo se componga hacia su interior (con oficinas o comercios, o con viviendas grandes o pequeñas, de buena o mala calidad). El impacto de la transformación material del paisaje urbano tiene un peso grande porque cambió estructuralmente la fisonomía de la ciudad que esos habitantes conocieron, particularmente en la zona norte, donde la escala barrial y las relaciones vecinales se perdieron. 
En tal sentido, la cantidad de edificios en altura construidos resulta crítica, ya que el acelerado proceso cuadruplicó esa cantidad en solo diez años. Estos edificios reemplazaron viviendas unifamiliares que componían la identidad local del paisaje urbano de la ciudad de La Plata, muchas de ellas de valor patrimonial. Viviendas que fueron reemplazadas por edificios en altura, que cambiaron la escala urbana, el asoleamiento y la vegetación del área fundacional, produciendo un indiscutible impacto negativo en el paisaje urbano.

Dichas transformaciones no tienen únicamente efectos formales o de apreciación o valoración de la arquitectura histórica de la ciudad, sino que, el cambio de tipología edilicia implica cambios en la organización social de los habitantes del área, con relación a quienes lo habitan y como lo usan. El recambio de tipologías edilicias y el reemplazo de muchas viviendas unifamiliares de varios dormitorios por pequeños departamentos de uno y dos ambientes, condiciona la estructura familiar de estos nuevos habitantes residentes de las áreas densificadas.

En procesos de densificación edilicia impulsados por el mercado inmobiliario y sin regulaciones normativas para mantener proporciones de usos no residenciales, las áreas afectadas tienden a volverse predominantemente residenciales perdiendo riqueza y diversidad de usos. Se trata de un tema crítico en los sectores que experimentan procesos de densificación. En este estudio resultó crítico el porcentaje de uso recreativo en la zona norte, la más afectada, ya que no se incrementó en igual proporción al incremento de viviendas, reduciendo la oferta de actividades deportivas y culturales en el sector y restando diversidad de usos, y estimulando viajes hacia otras zonas mejor provistas.

Referente a los nuevos habitantes, el proceso de optimización económica de los desarrolladores inmobiliarios, combinado con la ausencia de restricciones normativas que incentiven la diversidad tipológica, tiende a homogeneizar el perfil poblacional, atrayendo a una población de perfil “joven profesional con hogares pequeños" a estas reformuladas áreas residenciales centrales. Si bien el análisis del proceso demostró que la densidad poblacional no ha variado en la misma proporción que la densificación habitacional (ver Tabla 11), la composición de dicha población si se ha 
modificado durante el periodo analizado. Tanto la edad como el nivel educativo de la población reflejan el cambio demográfico ligado a las nuevas tipologías edificadas orientadas hacia comprador/inquilino joven y profesional.

De este modo, el cambio en el tamaño de hogar revela una tendencia de cambio hacia una población con hogares pequeños y sin hijos. Esto incide, de manera directa, en la pérdida de diversidad de población, hogares y actividades del sector, en el mediano y largo plazo; y de manera indirecta, incidiría en el desaprovechamiento del equipamiento de infraestructura escolar del área central, aumentando la necesidad de viajes de las familias numerosas que debieron irse del centro, pero deberán viajar cotidianamente hacia el centro en busca de dichos equipamientos.

\begin{tabular}{|c|c|c|c|}
\hline DIMENSION & VARIABLE & $\begin{array}{c}\text { VARIACIÓN } \\
\text { ZONA } \\
\text { NORTE }\end{array}$ & $\begin{array}{l}\text { VARIACIÓN } \\
\text { ZONA SUR }\end{array}$ \\
\hline \multirow{5}{*}{$\begin{array}{l}\text { CONFIGURACION } \\
\text { ESPACIO } \\
\text { CONSTRUIDO }\end{array}$} & Cantidad de torres / cuadra & CRITICA & MEDIA \\
\hline & Alturas predominante torre / cuadra & CRITICA & MEDIA \\
\hline & Sup. Const. / ha. & BAJA & BAJA \\
\hline & $\begin{array}{l}\text { Hitos o elementos referenciales } \\
\text { reconocidos }\end{array}$ & MEDIA & BAJA \\
\hline & Parque patrimonial existente & CRITICA & MEDIA \\
\hline \multirow{6}{*}{$\begin{array}{l}\text { ORGANIZACIÓN } \\
\text { SOCIAL }\end{array}$} & Uso comercial & BAJA & BAJA \\
\hline & Uso recreativo & CRITICA & CRITICA \\
\hline & Densidad de población & BAJA & BAJA \\
\hline & Tamaño de hogar (1 y 2 personas) & MEDIA & MEDIA \\
\hline & Población joven (20-39 años) & MEDIA & MEDIA \\
\hline & Mayor nivel educativo (universitarios) & MEDIA & MEDIA \\
\hline
\end{tabular}

Tabla 11. Relación entre el espacio construido y organización social en ambas zonas. Fuente: Elaboración propia en base a trabajo de campo y relevamiento Google Earth.

La consolidación de áreas centrales con viviendas tan pequeñas también condicionará en el futuro a que las familias y hogares vivan pocos años en esos lugares, el tiempo que les lleve hacer crecer sus familias, momento en el cual deberán mudarse fuera de las áreas centrales, hacia las periferias 
de la ciudad, por efecto de esta tendencia del mercado inmobiliario, que ofrece unidades de uno y dos ambientes de manera generalizadas en toda el área central (ver Imagen 10 en página 76).

El cambio en las tipologías de vivienda y en las características de la población, evidencia que los procesos de verticalización edilicia y los procesos de densificación poblacional no están necesariamente interrelacionados. Se verifica en el caso de La Plata que el proceso de verticalización no logra la intensificación de la ocupación del área central de la ciudad, lo que impide establecer una sinergia entre la cantidad de población y los servicios e infraestructura disponibles, la cual permitiría reducir la cantidad de viajes hacia el área central en busca de los servicios allí concentrados como objetivo del modelo compacto.

De esta manera, la densificación producida inició procesos de pérdida de diversidad urbana, tanto funcional como de la población residente, siendo este uno de los principales valores del modelo compacto. El proceso de verticalización edilicia transforma el paisaje urbano en su conjunto, desde la relación del edificio construido como modelador del espacio público, del edificio en relación a la ocupación futura, del edificio en relación a la diversidad de usos urbanos y del edificio en relación a los habitantes.

El análisis evidencia que el proceso de verticalización impactó de manera diferente en el uso del espacio urbano en ambas zonas. La zona norte, donde la transformación fue mayor, evidencia menor grado de involucramiento de los habitantes con el espacio urbano barrial y mayor presencia y valoración de actividades individuales. El cambio de la componente material se acompañó de un incremento de la individualización de las acciones en el espacio urbano, que por el contrario en la zona con menor grado de transformación (zona sur), conservó la participación colectiva, la organización barrial y el uso de los espacios públicos. Al respecto es necesario recordar que tanto la escasa actividad colectiva en la zona norte como el intenso uso del espacio público en la zona sur, preceden a este proceso. El proceso analizado en esta tesis potenció y ayudó a consolidar las tendencias y encontró más oportunidades en el espacio urbano residencial individual de la zona norte para desplegar arquitectura residencial tan densa y en altura. 
Estas relaciones, entre la transformación del espacio privado y los cambios en el uso y ocupación del espacio público, no están contempladas en las ordenanzas de uso del suelo. Esta norma se concentra en establecer porcentajes de ocupación del suelo, alturas y usos, pero con indicadores rígidos para cada parcela y no establece parámetros de conjunto urbano. Tampoco se exigen estudios para analizar el impacto de la densificación habitacional sobre la dinámica urbana, permitiendo que las transformaciones materiales incidan en la forma de uso, el movimiento y circulación en el espacio público.

Como señala Kullock (1994), es la organización social la que establece las condiciones del ambiente de la ciudad. Esto también afecta al paisaje urbano: incluso un paisaje que mantenga las características del espacio construido pero que modifique la organización, uso y funcionamiento del espacio público y privado, resulta en un paisaje que cambia por completo. Se puede concluir que la manera de construir la ciudad de manera individualizada, mediante la sumatoria de construcciones con parámetros vinculados a la parcela, sin visión de conjunto urbano, impide o anula procesos que contribuyan a la construcción de una unidad paisajística en la que entran en juego mayor cantidad de dimensiones.

\section{Dinámica y composición del espacio público}

La nueva forma del espacio construido impactó negativamente en el espacio público, ya que como el espacio vacío se define por el espacio lleno, la constitución de los bordes del espacio público está dada por la forma del espacio construido privado. En este sentido, las transformaciones morfológicas de espacio privado construido, antes analizadas, tienen efectos que inciden en la configuración del espacio público que afectan en términos visuales, de valoración, de calidad ambiental, de uso y de funcionamiento. 
En consideración a la valoración de los habitantes, el aspecto patrimonial resulta clave en la percepción del espacio público, ya que la pérdida de la belleza arquitectónica tradicional, que fue hasta ahora escenografía del espacio público, redefine la relación de los habitantes con estos lugares de esparcimiento. El parque patrimonial edilicio fue afectado principalmente en la zona norte donde se redujo drásticamente (ver Tabla 13). Esta pérdida de patrimonio resultó crítica frente al acelerado proceso de verticalización edilicia, que reemplazó edificios de valor patrimonial eliminando referencias urbanas y edilicias.

\begin{tabular}{|c|c|c|c|}
\hline DIMENSION & VARIABLE & $\begin{array}{l}\text { VARIACIÓN } \\
\text { ZONA NORTE }\end{array}$ & $\begin{array}{l}\text { VARIACIÓN } \\
\text { ZONA SUR }\end{array}$ \\
\hline \multirow{5}{*}{$\begin{array}{l}\text { CONFIGURACION } \\
\text { ESPACIO } \\
\text { CONSTRUIDO }\end{array}$} & Cantidad de torres x MZN & CRITICA & MEDIA \\
\hline & $\begin{array}{l}\text { Alturas predominante } \\
\text { torre } \times \mathrm{MZN}\end{array}$ & CRITICA & MEDIA \\
\hline & Sup. Const. x HA & BAJA & BAJA \\
\hline & $\begin{array}{l}\text { Hitos o elementos } \\
\text { referenciales reconocidos }\end{array}$ & MEDIA & BAJA \\
\hline & $\begin{array}{l}\text { Parque patrimonial } \\
\text { existente }\end{array}$ & CRITICA & MEDIA \\
\hline \multirow{4}{*}{$\begin{array}{l}\text { CONFIGURACION } \\
\text { ESPACIO } \\
\text { PUBLICO }\end{array}$} & Masa arbórea & CRITICA & CRITICA \\
\hline & Esp. Verde libre / hab. & CRITICA & CRITICA \\
\hline & Cantidad de autos & CRITICA & CRITICA \\
\hline & $\begin{array}{l}\text { Capacidad de } \\
\text { estacionamiento }\end{array}$ & CRITICA & CRITICA \\
\hline
\end{tabular}

Tabla 12. Relación entre el espacio construido y no construido en ambas zonas. Fuente: Elaboración propia en base a trabajo de campo y relevamiento Google

Earth.

Con relación al aspecto ambiental, la vegetación y masa arbórea pública, que según los resultados del estudio disminuyeron en ambas zonas, fueron afectadas tanto por prácticas constructivas como por la falta de sol y la reducción de espacio para crecer. Otro factor importante es la relación entre espacio verde y cantidad de habitantes (ver Tabla 12), teniendo en cuenta que los espacios verdes públicos no se incrementaron en el área central durante este periodo. Es clave tener en cuenta que el aumento de la construcción de viviendas aumenta la cantidad de población, 
distorsionando el balance ambiental que ofrecen los espacios verdes públicos en el área central de la ciudad.

En ambas zonas se concluye que el cambio de dinámicas en el espacio público es crítico. Tanto la cantidad de espacios verdes públicos por persona como la cantidad de árboles en la ciudad son componentes que tienen gran influencia en la forma de usar los espacios públicos. Poder transitar por una vereda fresca y con sombra en verano, o encontrar espacio en un parque para disfrutar un momento al aire libre, genera una sensación de confort que permite mejorar la experiencia de transitar de un lugar a otro de la ciudad y que las experiencias urbanas cobren significado en sí mismo.

Cabe destacar que, en el caso de La Plata, estas componentes responden a un aspecto ambiental y al mismo tiempo patrimonial, ya que la vegetación y los espacios verdes públicos son elementos del diseño urbano fundacional de la ciudad con fundamentos estéticos y de higiene, por lo que dichas componentes toman una doble dimensión al analizar el paisaje urbano de la ciudad.

Otro aspecto crítico en la transformación es la movilidad en el área central. El crecimiento de viviendas en ambas zonas generó un impacto negativo por el aumento de la cantidad de vehículos de los propios habitantes, lo que tuvo una repercusión negativa en la dinámica de circulación y estacionamiento de autos. Este hecho influye en el uso del espacio público: tanto por los automóviles que circulan por las calles como por los que están estacionados, se genera una sobrecarga de la estructura vial, y la capacidad de estacionamiento es crítica en ambos casos. La nueva dinámica urbana, genera una invasión de los espacios públicos que se constituyen como lugar de tránsito protagonizado por el automóvil. Esta es una variable crítica para el área central ya que el espacio público debe contemplar la demanda interna de circulación y de estacionamiento, en conjunto con la demanda externa de los 1.120 .000 viajes (Aón, Giglio, \& Cola, 2017) que se producen desde la periferia hacia el área central diariamente.

La experiencia urbana cambia sustancialmente según las formas de movilidad. Por un lado, la presencia dominante del automóvil en el espacio público restringe el vínculo de los habitantes 
con el espacio público, dando prioridad de uso al vehículo y relegando a las personas al uso de espacios residuales. Por otro lado, cuando la experiencia urbana se vive encapsulada dentro de un automóvil la relación con el espacio es nula y la percepción del paisaje se limita a lo visual. De esta manera se establece una relación contemplativa con el paisaje urbano.

DIMENSION

\begin{tabular}{ll} 
IDENTIFICACIÓN & $\begin{array}{l}\text { patrimonio } \\
\text { arquitectónico }\end{array}$ \\
\hline & $\begin{array}{l}\text { constante } \\
\text { transformación y caos } \\
\text { CaLORACIÓN }\end{array}$ \\
& $\begin{array}{l}\text { (de hogar con actividad) } \\
\text { ACCIÓN }\end{array}$ \\
TRANSFORMACIÓN & estado general peor
\end{tabular}

ESPACIO PUBLICO

Identidad barrial

límites de barrio

Presencia de elementos de referencia urbana

vegetación y espacios

verdes públicos histórica del barrio, el patrimonio arquitectónico y cultural

relaciones entre vecinos

actividad de grupos

organizados mejoras barriales

estado general mejor espacios de organización barrial

Tabla 13. Matriz de comparación de percepción. Fuente: Elaboración propia en base a entrevistas.

Como se puede ver en la Tabla 13, la valoración de las transformaciones incluye la transformación del espacio construido privado y también las transformaciones del espacio público. En el caso de la zona sur, la rehabilitación del predio de la estación de ferrocarril para actividades culturales y las actividades en el Parque Saavedra son un ejemplo. Como se ha señalado antes, en la zona sur la morfología del espacio construido se transforma lentamente manteniendo ciertas continuidades en el paisaje urbano, lo que hace que la percepción de las transformaciones de los habitantes sea positiva. En contraposición, en la zona norte las transformaciones se valoraron como negativas, ya que no se reconocen más cambios que la configuración del espacio construido, producto de la 
densificación habitacional y de los impactos derivados de ello. Esto evidencia la percepción y valoración de los espacios barriales, se construye desde el uso y disfrute de las actividades y de dichos espacios, incorporando el paisaje circundante a la memoria de las experiencias vividas. En el caso de la zona norte, a partir del relato de los entrevistados se pudo corroborar que en este tipo de paisajes no hay un vínculo más allá del simple hecho de circular por el espacio público y tampoco hay manifestaciones de uso del espacio público ni el cuidado o interés por el mismo. Los habitantes no registran rasgos propios del paisaje urbano ya que el espacio público del barrio es sólo un espacio intermedio entre su vivienda y el destino al que se dirigen, no se constituye como espacio en sí mismo. Dicha apatía por el espacio barrial incide en la construcción de identidad. La carencia de reconocimiento de características propias y de unidad paisajística, consolida una identidad de espacio intermedio, como transición entre y hacia otro barrio con identidades arraigadas.

Por el contrario, en zonas donde se conservan los elementos paisajísticos, las referencias materiales y simbólicas, hacen que se reconozcan identidades barriales arraigadas en los habitantes. En caso de la zona sur los habitantes reconocieron dos identidades barriales bien diferenciadas, relacionadas a componentes materiales (presencia de vegetación, los edificios históricos) de los paisajes propios de la zona. También destacaron el vínculo entre vecinos y el significado histórico del barrio como componentes simbólicas. Estos elementos pueden estar presentes en otras zonas de la ciudad, pero aquí son percibidos, reconocidos y valorados a partir del uso del espacio público.

\section{Transformación y apropiación del paisaje urbano}

La relación que los habitantes establecen con un paisaje que se ha transformado, tanto en su composición como en su dinámica, necesariamente enfrenta una adaptación que puede resultar de 
dos maneras: que los cambios sean asimilados con el tiempo y los vínculos se reinventen, o que los cambios sean rechazados y se desarrolle un vínculo con un paisaje por fuera de la zona de residencia. Los casos de estudio muestran situaciones que permiten situar espacialmente dichos procesos simbólicos.

Si bien se reconocieron importantes transformaciones del paisaje en los dos casos testigos analizados, con varias similitudes entre los elementos de la componente material, la percepción y la valoración de los procesos son muy diferentes. Mientras que en la zona sur los cambios se perciben como favorables, en la zona norte los cambios se perciben como negativos, invasivos y perjudiciales. Esto se debe a que la clave de la valoración del paisaje no radica en el espacio construido privado solamente, sino que está el espacio público del barrio, sus características, sus componentes, la forma de uso e intervención y el contexto edilicio que lo rodea.

Cuando el espacio público del barrio no contiene los elementos paisajísticos valorados, los habitantes no se apropian de su espacio barrial. Al analizar la percepción de las transformaciones en la zona norte se halló una desconexión con el paisaje barrial. Se encontró que los habitantes valoraron como atributos propios de su barrio la cercanía al centro y la buena accesibilidad, lo que es decir que la valoración esta puesta en factores externos al barrio o en factores que hacen a la calidad de sus actividades urbanas cotidianas individuales (proximidad, seguridad, higiene). Al destacar como valorable 'la relación de cercanía con...' se revela que el interés está puesto en actividades y/o espacios ubicados en otros sectores urbanos, es decir, que el espacio valorado y usado, apropiado efectivamente, se encuentra por fuera de su barrio de residencia.

En el otro extremo, en la zona sur, el estudio revela que el espacio público tiene contenido y significado para los habitantes residentes del lugar, es un espacio más para habitar y realizar actividades, deportivas, culturales, de esparcimiento, e incluso actividades productivas. En ese proceso se construye una imagen mental donde se vinculan elementos materiales del paisaje urbano con los recuerdos y significados otorgados a los espacios de la zona a lo largo de su 
historia. El espacio público se habita, se ve, se observa, se apropia y se carga de significaciones en la zona sur.

Como se ha dicho el paisaje urbano es relacional, y plantea un proceso circular donde la sociedad transforma el medio y el medio condiciona a la sociedad y su forma de ver y comprender el medio que habita. De esta manera se recompone la relación entre cultura y naturaleza, entre sujeto y objeto, entre razón y emoción. Con la misma circularidad, el proceso de apropiación del espacio se entiende como aquel en que la persona se hace a sí misma mediante las propias acciones en un contexto socio-cultural e histórico (Vidal Moranta \& Pol Urrútia, 2005). Es decir, el paisaje urbano actúa como resultado del proceso de apropiación espacial producido.

En este punto es donde la circularidad del proceso se ve truncado. En momentos en el que se interfiere modificando el paisaje, las referencias construidas mediante la apropiación se pierden, el vínculo con el espacio se establece desde lo funcional y no se desarrolla un lazo emocional. No se logra recomponer la relación circular entre cultura y naturaleza, entre el sujeto habitante y el objeto espacio urbano. Allí se evidencia que hay una ruptura del vínculo del habitante con el espacio urbano, un quiebre en el proceso de apropiación. 


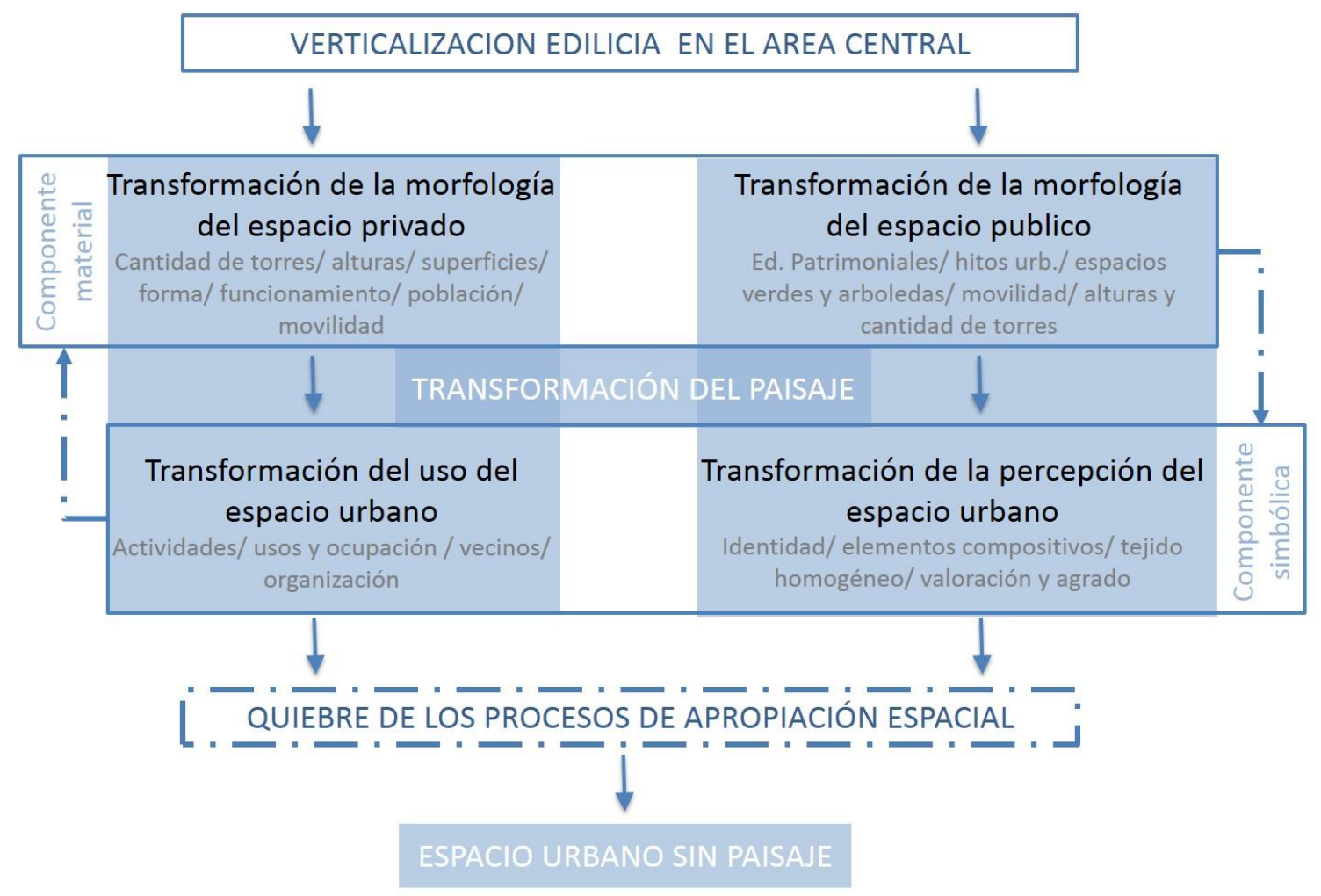

Cuadro 8. Síntesis analítica de los procesos y componentes producidos en el área central. Fuente: Elaboración propia 2019.

El espacio urbano de uso público, incluye la superficie necesaria para la circulación en la ciudad, pero también para el desarrollo de los contactos y vínculos sociales "que son la esencia de la ciudad como hecho colectivo" como expresa Rueda (2003). El espacio público es el protagonista del paisaje urbano, ya que es el lugar de observación desde el cual se percibe la morfología y la dinámica del paisaje y se lo experimenta.

De acuerdo con los resultados de este estudio, el espacio público resultó ser la dimensión más afectada por los procesos de densificación habitacional y verticalización edilicia en el área central de La Plata. Por un lado, se transformó la componente material, como se pudo evidenciar, a partir de la modificación de los espacios construidos privados que con sus fachadas le dan forma al espacio público y también por las actividades y movimientos que transformaron la dinámica del paisaje. Y, por otro lado, también se vio afectada la componente simbólica, como se verifica por medio de los relatos de los entrevistados, los espacios barriales afectados pierden su significado y sentido propio, transformándose en espacios de transición. 
Si bien en ambas zonas se puede ver que el impacto de la densificación habitacional se profundiza en esta dimensión clave, la diferencia está en los niveles de apropiación espacial que se registra en cada sector. La clave para entender esta diferencia se evidencia en relación a la velocidad de los procesos de transformación del paisaje, y la cantidad de elementos simbólicos, sus códigos culturales y los modos de uso de los espacios que fueron o no afectados por el proceso de verticalización edilicia en cada zona.

Recuperar estas claves en los procesos de transformación del paisaje, es importante principalmente en el caso de áreas centrales, que son por lo general, las zonas históricas con mayor provisión de equipamientos, mayor concentración de actividades y mayor acumulación de patrimonio arquitectónico y urbano. Estas áreas contienen referencias simbólicas no sólo para la población residente, sino también para la población de toda la ciudad y que también son, por esas mismas características, las zonas donde se dirigen las políticas urbanas de densificación con verticalización, que buscan consolidar un modelo compacto de crecimiento urbano como modelo de crecimiento sustentable.

Sin embargo, como se ha podido registrar y analizar, tanto en procesos agresivos de verticalización como en procesos de verticalización incipiente, la búsqueda de una pretendida mayor sustentabilidad urbana a través de la verticalización edilicia, sin tener en cuenta la dimensión paisajística (la historia, el espacio público, las actividades colectivas, las posibilidades de uso, el perfil de los nuevos residentes, la atractividad de los lugares) puede traer aparejado problemas tales como recambio de población, sobrecarga de las infraestructuras, empobrecimiento de los patrones de uso de los espacios públicos, pérdida de patrimonio urbano y ambiental, desvalorización estética y desapego emocional de habitantes históricos y nuevos problemas urbanos, todos estos, que pueden desencadenar el quiebre de procesos de apropiación de los espacios, lo que redunda en un espacio urbano sin imaginario, en una ciudad sin paisaje. 
REFLEXIONES FINALES 
A través del desarrollo de esta investigación se logró concretar el objetivo planteado: analizar la transformación del paisaje urbano del área central La Plata, provocada por el proceso de densificación habitacional a través de la verticalización edilicia y su incidencia en los procesos de apropiación del espacio urbano.

Se arriba a las conclusiones finales que se exponen en este capítulo luego de haber analizado el proceso de densificación habitacional de La Plata, a partir de la producción del parque edilicio y sus características morfológicas y tipológicas, de dimensionar los cambios materiales provocados por la verticalización edilicia y su incidencia en los aspectos simbólicos del paisaje urbano y de investigar la apropiación del espacio urbano analizando la percepción de los habitantes sobre el proceso de densificación y su valoración.

Al respecto, a través del nivel superior de análisis o contextual, se pudieron detectar y analizar los dos procesos de crecimiento que configuraron el paisaje de la ciudad de La Plata, principalmente orientados por la expansión horizontal, y con una densificación vertical que aparece en varios momentos de la historia de la ciudad, pero que se consolida como proceso, hacia finales del siglo XX y principios del siglo XIX. También se pudieron establecer vínculos entre las formas de ocupación características de cada periodo, las normativas que sustentaron dicha ocupación, las lógicas de los desarrolladores inmobiliarios y la expresión paisajística resultante. Se reconoció que en los primeros periodos no había una normativa que prefigurara la forma urbana, lo que permitió que se pierdan características del diseño fundacional, así como también se reconoció que en los últimos periodos de análisis la forma urbana resultante, no está pensada como paisaje urbano futuro sino como sumatoria de intervenciones particulares. Tanto la libertad que ofrece el instrumento normativo, para definir densidades habitacionales, cantidad de unidades funcionales y tamaños de departamentos, como la oferta de cocheras a los nuevos habitantes, van produciendo por defecto, un nuevo paisaje de mayor protagonismo de lo edificado y del automóvil, y menores oportunidades de encuentro y socialización. 
Asimismo, en el análisis del periodo de crecimiento vertical, se pudieron reconocer los procesos económicos impulsados por el sector inmobiliario y de la construcción que orientan dicho proceso, y el marco que prefigura el modelo de crecimiento urbano. A su vez, las formas que toman las acciones de los desarrolladores inmobiliarios en tal contexto normativo, producen recambios poblacionales que terminan siendo resultado de omisiones de la planificación normativa. Se corrobora a partir del análisis de la oferta habitacional de alquiler, que el mercado inmobiliario, desarrolla una oferta habitacional que tiende a consolidar un mercado de alquileres, por efecto de las pequeñas tipologías que produce._Esta preferencia de productos con los que el mercado inmobiliario desarrolla la "ciudad compacta", anticipa una tendencia en el mediano plazo de áreas centrales, construyendo un parque habitacional que estimula el recambio constante de población, que difícilmente pueda llegar a desarrollar vínculos emocionales con el espacio barrial.

El análisis en este nivel, permitió establecer tendencias de localización y las tipologías predominantes, a partir de lo cual se detectaron zonas homogéneas de crecimiento que sirvieron para hacer el recorte de los casos testigos y encarar el análisis detallado de las componentes del paisaje urbano.

Este abordaje, permitió dimensionar la transformación urbana y reconocer cuáles elementos fueron afectados por el proceso de densificación habitacional. Las nuevas tipologías de viviendas construidas, producen un contraste en la transformación de los elementos morfológicos del paisaje urbano preexistente que afecta el perfil urbano, las alturas dominantes, la cantidad de metros cuadros construidos incrementados, el patrimonio arquitectónico y urbano, y la masa arbórea. Asimismo, se reconocieron los elementos de la organización social que se modificaron en cada zona, desde el incremento de población, la tendencia al recambio de familias grandes por jóvenes profesionales, las demandas de servicios, la forma de uso del espacio público, el aumento de automóviles y en consecuencia el incremento de la congestión, es decir, el cambio de la dinámica del paisaje. 
En este sentido, a partir del trabajo realizado podemos reconocer que hubo efectivamente una transformación material del paisaje urbano del área central de La Plata, en un proceso que presenta distintos grados de desarrollo en cada zona analizada. A partir de esto, se reconoce una tendencia que contribuye a la degradación del paisaje urbano del área central en el largo plazo.

A partir del abordaje de la componente simbólica del paisaje urbano se pudo precisar que las transformaciones en el paisaje urbano de la ciudad son percibidas por los habitantes. Mediante el registro y análisis de las entrevistas a los residentes en ambas zonas, se detectó que la totalidad de los entrevistados reconocen el proceso de densificación habitacional en el periodo analizado. A su vez los habitantes reconocen realizar actividades cotidianas de carácter individual dentro del barrio, pero que no demuestran un uso colectivo de los espacios públicos de la zona, así como tampoco establecen relaciones con los vecinos, en espacios de organización barrial. Se encontró que, en el caso de la zona norte, las características del paisaje valoradas por los habitantes no son propias de la zona, sino que se relacionan con la ubicación geográfica y las posibilidades de conectividad y accesibilidad. Estos elementos dan pautas de una individualización de la experiencia urbana, y de un desapego hacia el hecho colectivo.

La pérdida de los elementos de referencia de identidad y valor paisajístico, en el caso de la ciudad de La Plata con un origen planificado, trasciende el parque patrimonial arquitectónico, y contempla características urbanas como el tejido, el perfil urbano y la forestación. Este proceso tiende a distanciar emocionalmente al habitante del entorno que habita, sin estimular la apropiación del espacio barrial. Como señala Jacobs (1961) las transformaciones urbanas inciden en la relación que los habitantes establecen con su barrio. Sin embargo, en los casos analizados, los entrevistados manifiestan que continuarían viviendo en el sector, a pesar de no destacar componentes positivos en el paisaje, ponderando atributos funcionales de la zona como la accesibilidad y la oferta comercial. De esta manera, se vislumbra que el vínculo desarrollado con el barrio es meramente funcional sin profundizar en un vínculo emocional con él, evidenciando una ruptura en el vínculo del habitante con el espacio habitado. 
En este sentido, se puede estimar qué sucedería cuando se rompen las relaciones de identidad y pertenencia de los habitantes de un barrio con su entorno, en los casos en que la población queda expuesta a un paisaje que le resulta ajeno y con la añoranza del paisaje perdido. Para comprenderlo, se plantean dos alternativas posibles a partir de las respuestas obtenidas. La primera es, la permanencia a disgusto en un paisaje urbano que resulta extraño, profundizando la no implicación en la dinámica barrial, idea que se verifica en el caso de los entrevistados de la zona norte, que señalan que continuarían viviendo en la zona, al mismo tiempo que destacan factores negativos al estado y valoración del paisaje de su barrio. La segunda deriva en el desplazamiento de los habitantes de la zona hacia otros barrios en busca de características paisajísticas y urbanas perdidas. También se desprende del relato de los entrevistados de la zona norte, su identificación con espacios públicos de otras partes de la ciudad y no con los espacios del propio barrio.

En referencia a los procesos que se dan en ambos sectores, si bien se reconoce que hubo un cambio en las características de la población, no puede afirmarse que se hayan iniciado procesos de "gentrificación". Por un lado, en la zona norte, hay un recambio habitacional dirigido a niveles socio económicos medio altos, que es el nivel socio económico históricamente predominante en este sector. Mientras que, para el caso de la zona sur, donde habitan personas de condición socio económica diversa, las trasformaciones recientes han sido gestionadas colectivamente, los nuevos espacios públicos no son espacios de consumo para niveles socio económicos altos y tampoco los nuevos edificios son de alta categoría o inaccesibles para la diversidad de habitantes de esta zona.

En cambio se corrobora que dentro del proceso de densificación habitacional existió un efecto indirecto que estimuló, y continúa estimulando, la desvinculación emocional de los habitantes históricos con el espacio barrial en la zona norte, proceso muy ligado a la ausencia de espacios y actividades colectivas, al avance cuantitativamente superior del desarrollo de espacio construido residencial en altura, a la ocupación de espacio público de circulación por automóviles transitando o estacionados y a las escasas oportunidades de encuentro que estas condiciones del nuevo tejido urbano producen. Mientras, la población residente de las nuevas viviendas en la zona norte, 
tampoco reconoce lugares comunes de encuentro o de identificación simbólica. La morfología resultante ofrece un paisaje compuesto por una predominancia de espacios privados residenciales, con espacios públicos invadidos por el uso del automóvil, generando una superioridad de actividades individuales por encima de colectivas.

A partir del trabajo realizado se pudo reconocer un patrón de identificación y valoración del paisaje barrial, que estaría marcado por el vínculo que tienen los habitantes con los espacios públicos y el grado de transformación que tuvo el paisaje: la valoración, en efecto, disminuye en relación directa con el mayor grado de densificación. Es posible afirmar que los procesos de apropiación se ven alterados, no sólo por la magnitud de las transformaciones sino también por la velocidad con que éstas se producen. Como se señala en el análisis de resultados, 'a mayor velocidad de los cambios materiales, menor la posibilidad de asimilación de los cambios y la capacidad de respuesta colectiva'. De esta manera, se verifica una tendencia de degradación y desvalorización del paisaje urbano que induciría en el mediano y largo plazo a un quiebre en los procesos de apropiación del espacio urbano. La transformación material del paisaje fractura en el imaginario de los antiguos habitantes las referencias de la ciudad construidas en el recorrido histórico, a la vez que las nuevas tipologías apuntan a un recambio de la población tradicional, condicionado por dos factores: el tamaño de las tipologías y la oferta habitacional orientada al mercado de alquileres.

Conforme a esto, se consiguió validar la hipótesis que plantea lo siguiente: "El proceso de densificación a partir de la verticalización edilicia en el área central de la ciudad de La Plata provoca cambios materiales y simbólicos en el paisaje urbano que producen el quiebre de los procesos de apropiación de la población histórica con su entorno”. El abordaje planteado permitió un análisis cualitativo del paisaje a partir de la técnica de entrevista estructurada, que contribuyó a reconocer patrones de identificación y valoración del paisaje, así como una tendencia de largo plazo de perdida de apropiación del espacio urbano. Sin embargo, se reconoce que es necesario profundizar la indagación con entrevistas en profundidad para analizar el origen y los motivos de estos patrones detectados. 
En relación a las preguntas del estudio original “¿Hasta qué punto es factible la transformación del paisaje urbano mediante procesos de densificación habitacional de áreas centrales sin que los habitantes pierdan las relaciones de identidad y pertenencia con el lugar?”, “QQué elementos o caracteres paisajísticos es necesario preservar?", claramente hay una clave en la generación de espacios públicos colectivos que es necesario preservar y/o generar así como también resulta necesario intervenir en los tamaños tipológicos con que densifica el mercado inmobiliario, a fin de evitar que los hogares grandes y medios sean expulsados de las áreas centrales de la ciudad.

En cuanto a la metodología formulada y aplicada en esta tesis, ella posibilita i) abordar desde múltiples escalas y con diversas aproximaciones, los procesos particulares de crecimiento urbano, detectando y profundizando en las zonas y periodos críticos respecto a la densificación habitacional mediante verticalización edilicia, pudiendo reconocer particularidades y diferencias dentro del mismo proceso en diferentes sectores urbanos. ii) integrar herramientas de análisis cuantitativo y cualitativo, lo que permite recomponer las dimensiones material y simbólica del paisaje urbano.

Asimismo, el trabajo realizado da cuenta de una posición respecto al camino teórico metodológico que reconoce la complejidad de los procesos urbanos y la importancia que tienen los fenómenos sociales frente a las políticas de planificación urbana. Es necesario revalorizar la multiplicidad de enfoques que son necesarios para interpretar al espacio urbano, pero, sobre todo, poner en relevancia el aporte sustancial que puede ofrecer a nuestra disciplina la mirada paisajística en la planificación de modelos de crecimiento urbano, en general, y procesos de densificación, en particular.

En este sentido, el análisis de las transformaciones paisajísticas y la percepción de dichos cambios, brindan pautas para la consideración de las políticas urbanas implementadas y se constituye como la base para la caracterización del modelo implementado, para la definición de políticas urbanas que tiendan a la sostenibilidad efectiva del modelo de crecimiento urbano. Para ello es necesario pensar no solamente en la configuración urbana sino tener en cuenta que se 
modifican indirectamente aspectos funcionales sociales y paisajísticos, que pueden revertir los efectos buscados por las políticas de densificación.

Es por esto, que ningún modelo que se pretenda sostenible puede soslayar los procesos de apropiación e identificación con el paisaje, marginando a los actores sociales de la toma de decisiones y las transformaciones sobre su ciudad. Incluir variables paisajísticas en los análisis de los procesos de transformaciones urbanas, en particular en los procesos de densificación que tienen gran impacto en la morfología urbana, complementa un análisis urbano multidimensional. Tanto en los casos donde se visualiza el inicio de procesos de densificación, como en casos en los que se planifica intensificar la densidad habitacional en un sector determinado de la ciudad, es necesario tener en cuenta este análisis para poder desplegar estrategias que regulen y mitiguen los posibles conflictos, relacionados con el nuevo perfil de habitantes de las áreas centrales, las nuevas formas de vida urbana de las familias numerosas que debieron irse fuera del centro y los modelos de planificación normativa posibles. En este sentido se abren nuevos interrogantes que plantean futuras líneas de investigación:

¿Cuáles serían los conflictos derivados del recambio poblacional periódico en áreas centrales?

¿Cuáles son las nuevas prácticas urbanas de las familias numerosas expulsadas de las áreas centrales?

¿Cuáles son los modelos posibles de planificación normativa que orienten ciudades compactas, complejas y diversas que no rompan los vínculos de los habitantes con sus áreas de residencia histórica? 
ANEXOS Y BIBLIOGRAFIA 


\section{Anexo catalogo patrimonial de la ciudad de La Plata}

Artículo 271 de la Ordenanza 9231 sancionada el año 2000, incorpora un catálogo de edificios patrimoniales que debían ser conservados, con el fin de proteger intereses públicos comprometidos en su inalterabilidad y jerarquización, en virtud de sus especiales valores y características culturales, históricas, artísticas, urbanísticas, arquitectónicas, paisajísticas y ambientales, y define 4 categorías de inmuebles a preservar a partir del valor de cada edificio y como aporta al paisaje: (i) Bienes patrimoniales de Interés Monumental, (ii) Bienes patrimoniales de Interés Arquitectónico (iii) Bienes patrimoniales de Interés Ambiental, (iv) Bienes patrimoniales de Interés Arqueológico.

El catálogo permite, mediante el análisis por cuadrantes, observar que la mayor cantidad de inmuebles de tipo I y II se encuentran en el cuadrante NE, coincidente con el sector de mayor densidad, pero con menor variación inter censal. Los cuadrantes NO y SE presentan gran cantidad de inmuebles catalogados bienes patrimoniales de Interés Ambiental, por el aporte de contexto al paisaje urbano. Sin embargo, no se consideran dichos inmuebles de valor arquitectónico en sí mismos, lo cual implica una vulnerabilidad frente a la tendencia de renovación edilicia presente en dichas zonas. 
Inventario de bienes patrimoniales catalogados. Fuente: Elaboración propia en base al catálogo de edificios patrimoniales de la Municipalidad de La Plata

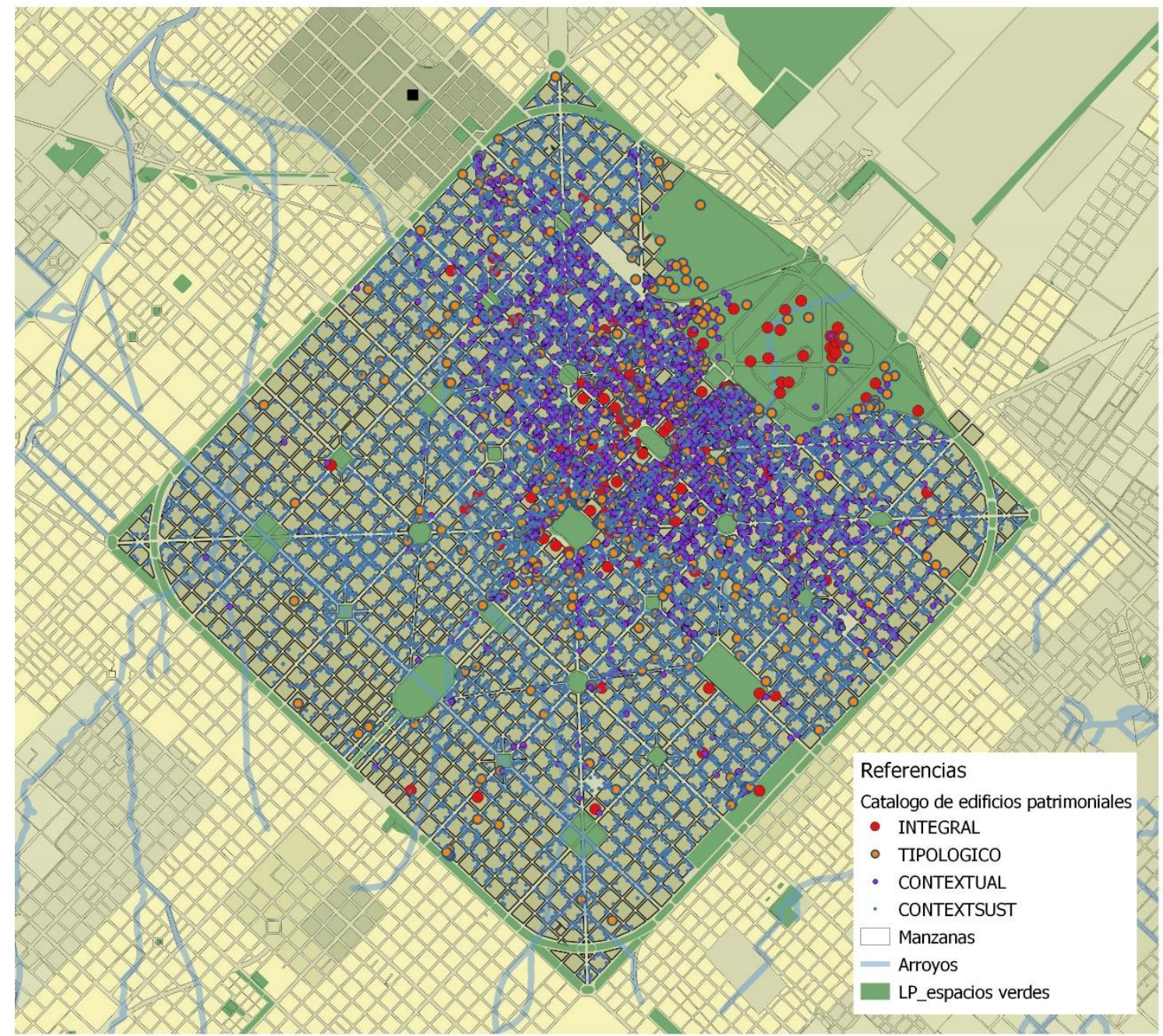

Decreto municipal 1579/06

\section{Digesto Municipal de La Plata}

LA PLATA, 17 de octubre de 2006

VISTO:

Lo dispuesto por los artículos 274, 275, 276, 280, 281 siguientes y concordantes de la Ordenanza 9231 y sus modificatorias; y

CONSIDERANDO:

Que, por dicha norma se dispuso la elaboración y aprobación, previo informe de la Comisión del Sitio, del catálogo definitivo de bienes a preservar como así también la elaboración de un Pre - inventario, por el que se deberá fijar los límites precisos de las zonas de preservación patrimonial, la asignación de los nuevos indicadores urbanísticos, las limitaciones al volumen, la determinación de usos admitidos y listado definitivo de bienes catalogados;

Que, la postulación del casco fundacional de La Plata a la Lista del Patrimonio Mundial de la UNESCO, proceso iniciado en 1995, actúa como proyecto unificador de programas y planes tendientes a la valoración y protección del patrimonio;

Que, si bien el inventario del patrimonio de la ciudad debe extenderse a otras escalas de componentes, como espacios verdes, áreas y sitios de interés y mobiliario urbano, la identificación de edificios y conjuntos edilicios de valor histórico, arquitectónico o ambiental constituye una tarea prioritaria que justifica su 
consideración específica. La dinámica de cambio en el tejido urbano implica en algunos casos la pérdida o alteración de componentes arquitectónicos caros para la historia y la identidad de la ciudad, lo que requiere definir medidas de protección que permitan, en el marco de la renovación y de la promoción de la actividad económica, conservar referentes importantes de la tradición cultural platense;

Que, la Ordenanza 9231, determina los criterios de selección de los bienes susceptibles de ser catalogados, así como el régimen de tratamiento y el procedimiento para la aprobación de intervenciones;

Que, a efectos de poner en marcha esta tarea, el inventario del patrimonio arquitectónico del casco fundacional de La Plata fue realizado por la Facultad de Arquitectura y Urbanismo de la Universidad Nacional de La Plata mediante Convenio con la Municipalidad, entre los años 2001 y 2003 y el inventario preliminar de los centros y áreas urbanas del partido fuera del casco fundacional, fue realizado, a su vez, por la Dirección de Planeamiento Urbano municipal;

Que, como resultado del trabajo realizado por la Facultad de Arquitectura y Urbanismo, fueron identificados edificios que presentan valor histórico, arquitectónico o ambiental, los que se agruparon en categorías para las cuales se definieron los grados de valor y de protección;

Que el total de edificios identificados en el casco fundacional de La Plata ascendió a 13.336, quedando luego de la revisión y ajuste del catálogo del patrimonio arquitectónico del casco fundacional, por parte de la Dirección de Preservación de Patrimonio, un total de 1826 edificios correspondiendo 40 a la categoría de protección Integral, 171 a la de Protección Estructural y 1559 a la de Protección Contextual, quedando afectadas a Protección Cautelar 227 parcelas;

Que, en el mismo orden se ha procedido a definir la propuesta de preinventario, determinándose los bienes patrimoniales que serán incluidos en la etapa final de inventario, mediante la formulación de la Propuesta de Zonas Especiales de Preservación Patrimonial -Casco Urbano Fundacional de La Plata- las que han sido definidas como Zona Paseo del Bosque, Áreas Universitarias e Hipódromo, Zona Avenida 13, Parque Saavedra y Barrio Meridiano V, Zona Escuela 8 y Zona Eje Monumental, área central y extensión por Avenida 1 hacia Tolosa, fijándose el tratamiento de edificios catalogados como patrimonio arquitectónico y los incentivos propuestos para propietarios de edificios catalogados;

Que, por todo lo expuesto y en el marco de lo dispuesto por los artículos 274, 275, 276, 280, 281 siguientes y concordantes de la Ordenanza 9231 y sus modificatorias, corresponde el dictado del presente acto administrativo;

POR ELLO:

\section{EL INTENDENTE MUNICIPAL} DECRETA

ARTÍCULO $1^{\circ}$ : Apruébase el Catálogo de bienes que integran el patrimonio arquitectónico del casco fundacional de La Plata, conforme a plano y listado de bienes integrantes que conforman los Anexos I y II del presente decreto.

ARTÍCULO $2^{\circ}$ : Los bienes catalogados han sido categorizados según la nomenclatura establecida por el artículo $287^{\circ}$ de la Ordenanza 9231 y sus modificatorias, en:

Bienes patrimoniales de Interés Monumental: Edificios públicos o privados con alto valor histórico y/o arquitectónico, cuya significación excede el marco local.

Bienes patrimoniales de Interés arquitectónico: Edificios públicos o privados con valor histórico y/o arquitectónico.

Bienes patrimoniales de Interés ambiental: Edificios públicos o privados que pueden no presentar valores históricos o arquitectónicos destacados pero que contribuyen, por contigüidad con otros similares, al carácter o identidad del área de inserción.

ARTÍCULO $3^{\circ}$ : Los bienes catalogados, incluidos en las categorías determinadas en el artículo $2^{\circ}$, tendrán los siguientes grados de protección, de acuerdo al régimen de preservación previsto en el artículo $277^{\circ}$ de la Ordenanza 9231:

Edificios de Categoría A

Tendrán un grado de Protección Integral, consistente en la conservación de los rasgos exteriores e interiores que otorgan al edificio sus valores, incluyendo esquema tipológico, volumen, fachada, disposición interior, aspecto interior de los espacios principales, elementos de ornamentación exterior e interior.

Edificios de Categoría B

Tendrán un grado de Protección Estructural, consistente en la conservación del esquema tipológico del edificio, incluyendo su composición, volumen y fachada.

Edificios de Categoría C

Tendrán un grado de Protección Contextual, consistente en la conservación de los rasgos que hacen que el edificio contribuya al carácter del área, incluyendo volumen sobre la línea de frente de la parcela y su aspecto exterior. 
ARTÍCULO $4^{\circ}$ : Toda intervención a realizarse en los bienes catalogados y categorizados, de acuerdo a los diferentes grados de protección determinados en el artículo $3^{\circ}$, además de los previsto en los artículos $278^{\circ}$ y $279^{\circ}$ de la Ordenanza 9231 y sus modificatorias, se ajustarán a las siguientes normas de intervención: Grado de Protección Integral.

Las intervenciones se orientarán a poner en evidencia y salvaguardar los valores del edificio y al respeto y la puesta en valor de su autenticidad de diseño, materiales y ejecución.

Intervenciones permitidas:

Acciones de mantenimiento, conservación, restauración, consolidación.

Afectación a nuevos usos, compatibles con las características físicas del edificio y con el carácter del área de inserción.

Eliminación de partes no originales que no posean valor en sí mismas y que alteren la composición o aspecto originales.

Incorporación de componentes exigidos por cuestiones de habitabilidad o confort en la medida que se compatibilicen con el edificio y no pongan en riesgo sus valores.

1.2. Intervenciones no permitidas:

Alteraciones en el volumen o en el aspecto exterior.

Alteraciones en los espacios interiores significativos del edificio.

Eliminación de partes originales.

Eliminación de ornamentación, exterior o interior.

Remoción de escultura u obras de arte integradas a la estructura del edificio.

Tratamientos de superficies que pongan en riesgo la autenticidad de diseño, materiales y mano de obra.

Grado de Protección Estructural.

Las intervenciones se orientarán a poner en evidencia y salvaguardar los valores del edificio y al respeto y la puesta en valor de su autenticidad de diseño, materiales y ejecución. Se permitirán modificaciones que no alteren la sustancia tipológica del inmueble.

2.1. Intervenciones permitidas:

Acciones de mantenimiento, conservación, restauración, consolidación.

Afectación a nuevos usos, compatibles con las características físicas del edificio y con el carácter del área de inserción.

Eliminación de partes no originales que no posean valor en sí mismas y que alteren la composición o aspecto originales.

Incorporación de componentes exigidos por cuestiones de habitabilidad o confort en la medida que se compatibilicen con el edificio y no pongan en riesgo sus valores.

Modificaciones internas que no alteren la estructura tipológica del edifico ni los espacios más significativos. Ampliaciones que resulten compatibles con la estructura tipológica. Se podrán estudiar ampliaciones en altura limitadas en la medida que las mismas no alteren la estructura tipológica ni el aspecto exterior.

2.2. Intervenciones no permitidas: Alteraciones en el aspecto exterior.

Alteraciones en los espacios interiores significativos del edificio.

Eliminación de partes originales.

Eliminación de ornamentación, exterior o interior.

Remoción de escultura u obras de arte integradas a la estructura del edificio.

Tratamientos de superficies que pongan en riesgo la autenticidad de diseño, materiales y mano de obra del edificio.

Grado de Protección contextual.

Las intervenciones se orientarán a conservar los valores por los cuales el edificio contribuye al carácter del área de implantación.

3.1. Intervenciones permitidas:

Acciones de mantenimiento, conservación, restauración, consolidación.

Afectación a nuevos usos, compatibles con las características físicas del edificio y con el carácter del área de inserción.

Eliminación de partes no originales que no posean valor en sí mismas y que alteren la composición o aspecto originales.

Incorporación de componentes exigidos por cuestiones de habitabilidad o confort en la medida que se compatibilicen con el edificio y no pongan en riesgo sus valores.

Modificaciones internas, con la recomendación que, en lo posible, no alteren la estructura tipológica del edificio ni los espacios más significativos.

Ampliaciones que, en lo posible, puedan ser compatibles con la estructura tipológica. Se podrán incrementar en forma limitada la altura del edificio en la medida que no se alteren los valores por lo que el mismo contribuye al carácter del entorno y el volumen resultante sea compatible con las características del área de inserción. 
3.2. Intervenciones no permitidas:

Alteraciones en el aspecto exterior.

Alteraciones en los espacios interiores significativos del edificio.

Eliminación de partes originales que contribuyen al carácter del área.

Eliminación de ornamentación exterior.

Remoción de escultura u obras de arte integradas a la estructura del edificio. Tratamientos de superficies de fachadas que pongan en riesgo la autenticidad de diseño, materiales y mano de obra del edificio.

La referencia a "espacios interiores significativos", alcanza a los locales principales de los edificios, donde se pueden encontrar riqueza espacial, como también ornamentación o tratamiento de superficies de calidad. ARTÍCULO $5^{\circ}$ : Los edificios que no están categorizados por su valor histórico, arquitectónico o ambiental, pero que resultan linderos a inmuebles catalogados con grados de Protección Integral o Estructural y los inmuebles integrados a grupos o conjuntos de edificios catalogados con Protección Contextual, tendrán un grado de Protección Cautelar.

ARTÍCULO 6 $6^{\circ}$ : A los inmuebles identificados con grado de Protección Cautelar, que sean intervenidos o reemplazados por otros nuevos, se les podrá establecer mediante estudio particularizado, limitaciones al volumen y especificaciones al proyecto con el fin de lograr su integración armónica de los edificios catalogados linderos, en un todo de acuerdo a lo previsto en el artículo $135^{\circ}$ de la Ordenanza 9231 y sus modificatorias.

ARTÍCULO 7º: Formúlase la Propuesta de Preservación, estableciéndose los límites y las Zonas Especiales de Preservación Patrimonial en el Casco Urbano Fundacional de La Plata, con la asignación de indicadores urbanísticos, la determinación de usos admitidos y las limitaciones al volumen, que regirán para las manzanas y parcelas comprendidas en las mismas, que conforman el Anexo III del presente decreto, de acuerdo a la siguiente clasificación y fijación de pautas de intervenciones a las que someterán dichos bienes: Zona Paseo del Bosque, Áreas Universitarias e Hipódromo.

Esta zona será objeto de un Plan Especial que contemple y determine usos, ocupación y explotación del suelo, conservación del espacio público, conservación y renovación del patrimonio forestal, conservación y restauración del patrimonio arquitectónico y escultórico, conservación y renovación del mobiliario urbano y señalización.

1.1. Delimitación de zona:

Desde calle 41 y vías de Ferrocarril General Roca, por éstas hasta avenida 122, por ésta hasta vías, por éstas hasta calle 64, por ésta hasta boulevard 113, por ésta hasta intersección de calle 116 y avenida 60, por ésta hasta avenida 1, por ésta hasta calle 47, por ésta hasta intersección con vías, por éstas hasta avenida 44, por éstas hasta calle 116, por ésta hasta diagonal 74, por ésta hasta calle 41, por ésta al inicio.

Zona Avenida 13, Parque Saavedra y Barrio Meridiano V.

2.1. Se mantienen los usos e indicadores urbanísticos establecidos por la Ordenanza 9231/00 y modificatorias, para la Zona de pertenencia.

2.2. Alturas máximas propuestas:

2.2.1. Zona Avenida 13 y Parque Saavedra:

18 metros: Manzanas comprendidas en la delimitación de la zona que va desde avenida 13 por frente a Plaza Máximo Paz (norte) hasta avenida 60, por ésta hasta calle 12, por ésta hasta calle 64, por ésta hasta calle 11, por ésta hasta calle 68 , por ésta hasta calle 14 , por ésta hasta avenida 66 , por ésta hasta calle 15 , por ésta hasta calle 65 , por ésta hasta calle 14 , por ésta hasta calle 61 , por ésta hasta calle 15 , por ésta hasta avenida 60, por ésta hasta Plaza Máximo Paz frente oeste, por ésta al inicio.

2.2.2. Zona Calle 12 San Francisco a Estación Circunvalación:

12 metros: Manzanas comprendidas en la delimitación de la zona que va desde intersección de esquina calle 68 y 11, por ésta hasta avenida 72, por ésta hasta calle 12, por prolongación de ésta incluyendo Boulevard de circunvalación y Estación Circunvalación hasta avenida 13, por ésta hasta calle 71, por ésta hasta calle 14 , por ésta hasta calle 70 , por ésta hasta avenida 13, por ésta hasta calle 68 , por ésta al inicio.

2.2.3. Zona Entorno a Estación Meridiano V:

9 metros: Manzanas comprendidas en la delimitación de la zona que va desde esquina avenida 13 hasta avenida 72 incluyendo parque de circunvalación, por ésta hasta avenida 19, por ésta hasta calle 70, por ésta hasta calle 18 , por ésta hasta calle 68 , por ésta hasta calle 16 , por ésta hasta calle 70 , por ésta hasta calle 14 , por ésta hasta calle 71, por ésta al inicio.

Zona Escuela 8.

3.1. Se mantienen usos e indicadores urbanísticos establecidos por la Ordenanza 9231/00 y modificatorias, para la Zona de pertenencia.

3.2. Altura máxima propuesta:

12 metros: Manzanas comprendidas en la delimitación de la zona que va desde esquina de calle 56 y 15 , por ésta hasta calle 58, por ésta hasta calle 17, por ésta hasta calle 56, por ésta al inicio.

Zona Eje Monumental, Área Central y Extensión por Avenida 1 hacia Tolosa. 
4.1. Se mantienen los usos e indicadores urbanísticos establecidos por la Ordenanza 9231/00 y modificatorias, para la Zona de pertenencia.

4.2. Alturas máximas propuestas:

4.2.1. Zona Central 1:

18 metros: Manzanas comprendidas en la zona delimitada que va desde esquina de calle 43 y avenida 1 , por ésta hasta calle 58 , por ésta hasta calle 4 , por ésta hasta calle 59 , por ésta hasta calle 5 , por ésta hasta calle 61 , por ésta hasta calle 8 , por ésta hasta calle 59 , por ésta hasta calle 6 , por ésta hasta calle 43 , por ésta al inicio: altura máxima 18.00 metros.

4.2.2. Zona Entorno Plazoleta "Noche de los Lápices".

12 metros: Manzanas comprendidas en la zona delimitada que va entre calle 7, desde calle 61 a calle 62 , por ésta hasta calle 9, por ésta hasta avenida 60, por ésta hasta calle 8 , por ésta al inicio.

4.2.3. Zona Avenida 7:

24 metros: Manzanas comprendidas en la zona delimitada que va desde intersección esquina 45 y calle 6 , por ésta hasta calle 59 , por ésta hasta calle 8 , por ésta hasta calle 45 , por ésta al inicio: altura máxima 24.00 metros.

4.2.4. Zona Central 2:

18 metros: Manzanas comprendidas en la zona delimitada que va desde intersección de calle 46 y calle 8 , por ésta hasta calle 59, por ésta hasta calle 9, por ésta hasta intersección de diagonal 73 y calle 58, por ésta hasta calle 14 , por ésta hasta calle 47 , por ésta hasta calle 11 , por ésta hasta calle 46 , por ésta hasta calle 8. 4.2.5. Zona Central 3:

12 metros: Manzanas comprendidas en la zona delimitada que va desde intersección de calle 48 y 14 , por ésta hasta calle 55, por ésta hasta intersección de diagonal 74 y calle 15 , por ésta hasta calle 54 , por ésta hasta calle 20 , por ésta hasta calle 50 , por ésta hasta calle 16 , por ésta hasta calle 49 , por ésta hasta intersección de diagonal 73 y calle 15 , por ésta hasta calle 48 , por ésta al inicio.

4.5.6. Zona Residencial entre Hipódromo y Universidad:

2 metros: Manzanas comprendidas entre la zona delimitada que va desde intersección de avenida 44 y vías, por ésta hasta calle 47 , por ésta hasta avenida 1 , por ésta al inicio.

4.2.7. Zona Avenida 1 a Tolosa.

12 metros: Manzanas comprendidas en la zona que va desde intersección de calle 115 hasta avenida 44, por ésta hasta avenida 1 , por ésta hasta calle 43 , por ésta hasta calle 4 , por ésta hasta calle 40 , por ésta hasta diagonal 74 , por ésta hasta calle 2 , por ésta hasta calle 34 , por ésta hasta avenida 1 , por ésta hasta calle 35 , por ésta al inicio.

4.3. En las zonas identificadas precedentemente no se aplicará el $70 \%$ de premio al factor de ocupación total FOT y a la densidad.

4.4. En las manzanas comprendidas en la Zona en que haya un predominio de edificios catalogados (más del $50 \%$ del total), los edificios no catalogados existentes se equipararán a edificios con Protección Cautelar.

Mediante estudio particularizado se podrá considerar el volumen a edificar, sin imponer restricciones a la aplicación de indicadores FOT y densidad.

ARTÍ́CULO $8^{\circ}$ : Como parte de la Propuesta de Preservación, para los propietarios de bienes catalogados, se proponen los siguientes incentivos:

Asesoramiento técnico por parte de la Dirección de Preservación de Patrimonio y de la Comisión del Sitio (CODESI) relativo a alternativas y posibilidades de intervención.

Exención de los Derechos de Oficina, para la realización de trámites vinculados con obras permitidas.

Exención del pago de los Derechos de Construcción, para el otorgamiento de permisos de obras permitidas. Exención de la Tasa de Servicios Urbanos Municipales (SUM), con porcentajes de aplicación según categoría de valor y grado de protección de los inmuebles, de acuerdo al siguiente detalle:

Edificios con Protección Integral: 100\%

Edificios con Protección Estructural: 70\%

Edificios con Protección Contextual: 50\% La exención queda condicionada a que el importe no efectivizado por dicha tasa será destinado por los propietarios para el mantenimiento y conservación de los inmuebles.

ARTÍCULO 9: La Dirección Coordinación de Obras Particulares, procederá a implementar el Registro de Oposición previsto en el artículo $283^{\circ}$ de la Ordenanza 9231 y sus modificatorias.

ARTÍCULO $10^{\circ}$ : La Dirección Coordinación de Obras Particulares, comunicará en su parte pertinente a todos los propietarios de los bienes inmuebles catalogados y alcanzados, por lo dispuesto en los artículos $1^{\circ}$ a $5^{\circ}$ del presente decreto, quienes podrán formular oposición fundada por un periodo de 60 días hábiles administrativos, contados a partir de su notificación, con el objeto de solicitar la recategorización, desafectación o cualquier otra modificación del bien de su propiedad.

ARTÍCULO $11^{\circ}$ : Dentro del plazo de 60 días hábiles administrativos, contados a partir de la publicación del presente decreto, quienes acrediten interés legítimo podrán formular oposición fundada ante la 
Dirección de Preservación de Patrimonio, a la Formulación de la Propuesta de Preservación, establecida en los artículos $7^{\circ}$ y $8^{\circ}$ del presente decreto.

ARTÍCULO $12^{\circ}$ : Vencidos los plazos previstos en los artículos $10^{\circ}$ y $11^{\circ}$ del presente Decreto, se tendrá por Cerrado el Registro de Oposición, debiendo elevarse en un plazo de 30 días hábiles, el listado final de los Bienes Catalogados y la Propuesta de Preservación para su aprobación por el Concejo Deliberante, previo informe a la Comisión del Sitio (CODESI).

ARTÍCULO 13ㅇ: El presente Decreto será refrendado por el Sr. Subsecretario de Planeamiento y Desarrollo Urbano.

ARTÍCULO 14: Regístrese, comuníquese, publíquese y archívese.

DECRETO No 1579

Dr. Julio César Alak. Intendente

Arq. Ariel Iglesias. Subsecretario de Planeamiento y Desarrollo Urbano 


\section{Anexo Análisis demográfico}

Tabla de análisis demográfico zona norte años 2001 y 2010 y sus proyecciones. Fuente: Elaboración propia en base a censos 2001, censo 2010 y Proyecciones y estimaciones al 2025 del INDEC

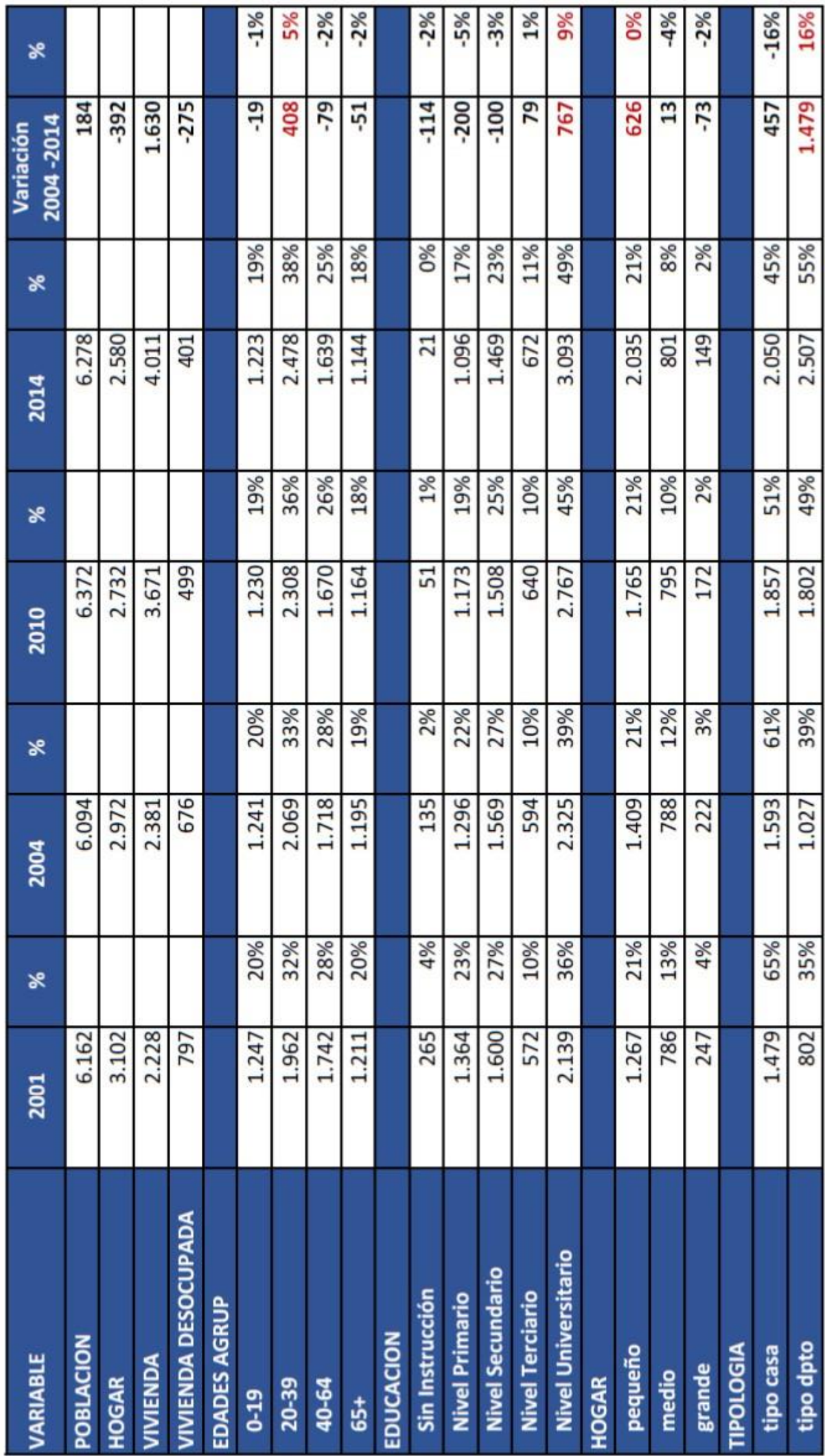




\section{Anexo Análisis demográfico}

Tabla de análisis demográfico zona sur años 2001 y 2010 y sus proyecciones. Fuente:

Elaboración propia en base a censos 2001, censo 2010 y Proyecciones y estimaciones al 2025 del

INDEC.

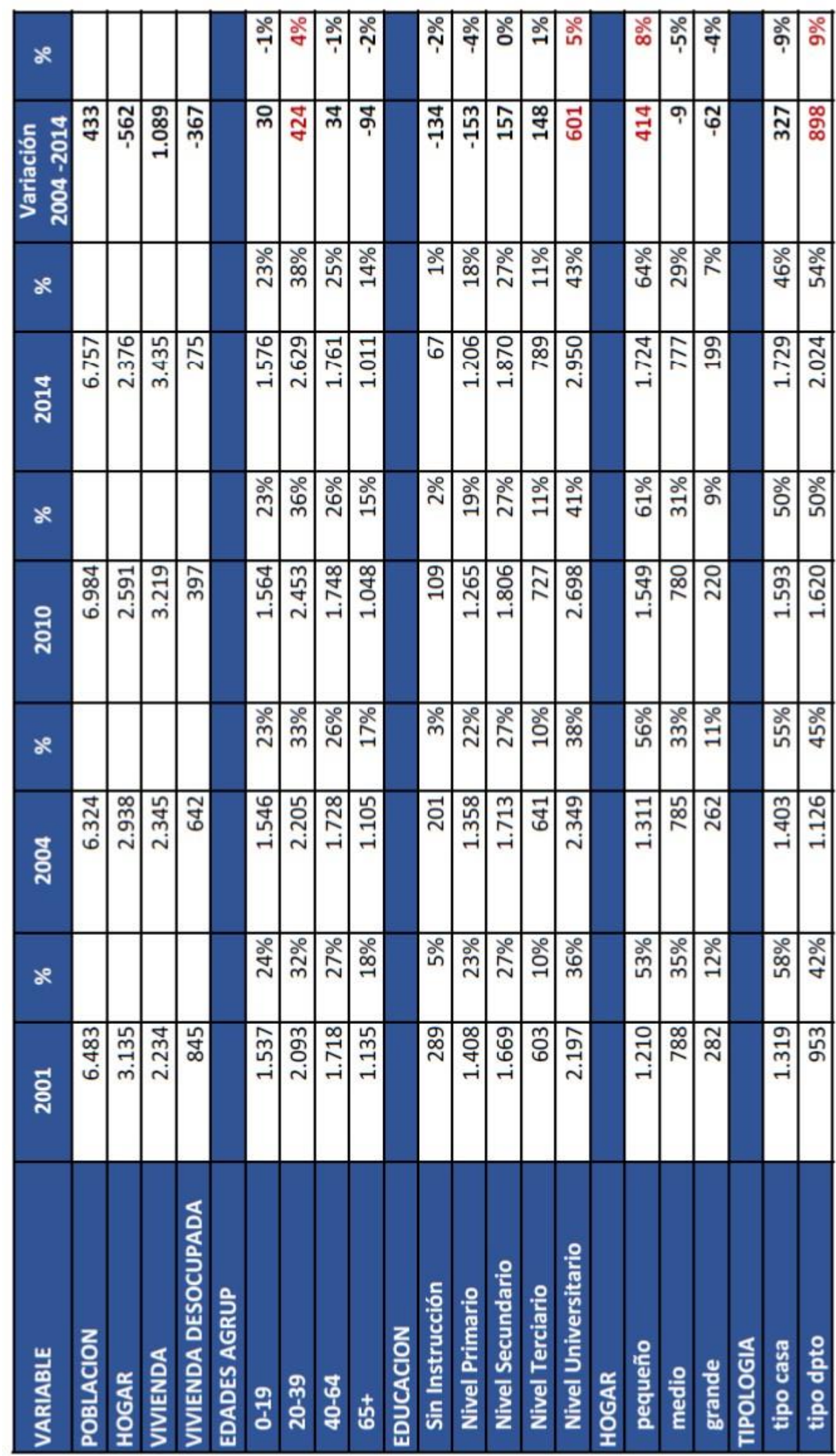




\section{Bibliografía}

Alderoqui, S. (2002). Enseñar a pensar la ciudad. Buenos Aires: Paidós.

Aliata, F., \& Silvestri, G. (2001). El Paisaje como Cifra de Armonia. Buenos Aires: Nueva Vision.

Aón, L. (2001). Criterios de sostenibilidad territorial para la evaluación de proyectos ¿El paisaje como instrumento de evaluación? En Paisajes. Reflexiones (págs. 149-178). La Plata: Ediciones al margen .

Aón, L., \& al, e. (2008). Potencialidades ambientales del suelo urbanizado en Escenarios de densificación de Áreas centrales: El caso del casco antiguo de la ciudad de La Plata. $44^{\circ}$ ISOCARP CONGRESS. ISOCARP CONGRESS.

Aón, L., \& Frediani, J. (2010). La categoria de patrón territorial y el concepto de lugar aplicados al espacio residencial de la periferia del Partido de La Plata. Parrafos Geograficos. , vol 9 n¹ ISSN 1666-5783.

Aón, L., Giglio, L., \& Cola, C. (2017). Patrones modales de movilidad y desarrollo urbano no planificado en la ciudad de La Plata. Transporte y Territorio, 117-144 $\mathrm{n}^{\circ} 17$ ISSN $1852-7175$.

Baringo Ezquerra, D. (2013). La tesis de la producción del espacio en Henri Lefebvre y sus críticos: un enfoque a tomar en consideración. QUID $16 N^{\circ} 3,119-135$.

Berque, A. (2006). Trayeccion y realidad del paisaje. Traduccion: Devora Manuel.

Borja, J., \& Muxí, Z. (2001). Centros y espacios públicos como oportunidades. Perfiles Latinoamericanos, 19: 115-130.

Borsdorf, A. (2003). Hacia la ciudad fragmentada. Tempranas estructuras segregadas en la ciudad latinoamericana. Scripta Nova, Vol. VII, núm. 146(122).

Cañellas, E., Muñoz, M., Natale, D., \& Tella, G. (2009). Las torres como nuevo tipo edilicio del conurbano. Actores, procesos y mecanismos de transformación en San Miguel. Actas $X$ Seminario Red Muni Nuevo rol del Estado, nuevo rol de los Municipios. La Matanza: UNLAM.

Carrión, F. (2010). El nuevo patrón de urbanización en América Latina. Textos urbanos No. 5 , , $7-24$.

Cicollela, P. (2010). Capitalismo global y transformaciones metropolitanas: enfoque e instrumentos para repensar el desarrollo urbano. En Otro desarrollo urbano. Buenos Aires: CLACSO.

Consejo de Europa. (2000). Convenio europeo del paisaje . Florencia.

Corraliza Rodriguez, J. A. (2009). Emoción y espacios públicos: La experiencia humana de los escenarios urbanos. Jornada de El árbol en el diseño. Madrid: Universidad Autónoma de Madrid. 
Cullen, G. (1961). El paisaje urbano. Buenos Aires: Blume.

DataUrbis. (2011). Censo 2010: población y vivienda en La Plata. La Plata: www.dataurbis.com.ar.

Donadieu, P. (2006). La sociedad paisajista. La Plata: Editorial EDULP. Isbn: 950-34-0361-8.

Erlij, M. (2004). Patrimonio y ciudad: sustentabilidad urbana. Urbano, año $7, n^{\circ} 10,28-30$.

Esparza, J. (2012). La noción de paisaje como resultado de las condiciones territoriales, medio ambientales y perceptivas de los habitantes. El caso del gran la plata. La Plata: UNLP.

Figueras Bellot, P. (2002). Prólogo. En S. Alderoqui, \& P. Penchansky, Ciudad y ciudadanos. Aportes para la enseñanza del mundo urbano (págs. 17-22). Buenos Aires: Paidós.

Fotos históricas de La Plata. (10 de 1 de 2018). www.facebook.com/fotoshistoricasdeLaPlata/. Obtenido de https://www.facebook.com/pg/fotoshistoricasdeLaPlata/photos/?ref=page_internal

Freaza, N., \& Aón, L. (2012). Una ciudad, dos modelos: Fractura del tejido urbano y social en la ciudad de La Plata. Acta del $1{ }^{\circ}$ Congreso de Ecología Urbana. Los Polvorines: UNGS.

Frediani, J. C. (2010). Lógicas y tendencias de la expansión residencial en áreas periurbanas. El Partido de La Plata, Buenos Aires, Argentina, entre 1990 y 2010. La Plata: Universidad Nacional de La Plata. Facultad de Humanidades y Ciencias de la Educación.

Fundación de Estudios para Desarrollos Inmobiliarios. (2012). Otras Lógicas. Análisis comparado de las lógicas y modelos de negocios vigentes en la producción urbanainmobiliaria de las ciudades de Buenos Aires, Rosario y Córdoba - Periodo 2002/2012. Buenos Aires: FEDI.

Goenaga, V. (2001). El paisaje como dimensión cognitiva. Conservación inventiva en área ecológica protegida Barrio Nirvana. En M. d. Ciudad, Paisaje. Reflaxiones (págs. 111147). La Plata: Edisiones Al Margen.

Google Earth. (s.f.). Imagenes satelitales año 2004 y 2014.

Hidalgo Villodres, C. (1998). Apego al lugar. Ambietos, dimensiones y estilos. España: Universidad de La Laguna .

INDEC. (2001). Censo 2001. Obtenido de http://www.indec.mecon.ar/micro_sitios/webcenso/index.asp

INDEC. (2010). Censo 2010. Obtenido de http://www.indec.gov.ar/nivel4_default.asp?id_tema_1=2\&id_tema_2=41\&id_tema_3= 135

Jacobs, J. (1961). Muerte y vida en las grandes ciudades americana. Madrid: Ediciones península.

Jelin, E. (2002). Los trabajos de la memoria. Madrid: Siglo XXI . 
Jensen, K. (2018). Paisajes vacantes. El paisaje y los espacios verdes en la periferia platense. La Plata: UNLP.

Karol, J. (2005). Modelos teóricos sobre la estructuración urbana. En, archivo teóricos de Planeamiento I. Cátedra de Planeamiento RKT, Ravella, Olga-Karol, Jorge - Tauber, Fernando. Facultad de Arquitectura y Urbanismo. Universidad. Nacional de La Plata.

Karol, J. (2013). Procesos de estructuración, fragmentación y desestructuración urbana. En, Seminario de Teoría e Historia de la Ciudad. Maestría en Paisaje, Medio ambiente y Ciudad. Facultad de Arquitectura y Urbanismo. Universidad. Nacional de La Plata.

Karol, J. (2014). Reconocimiento de dimensiones, percepciones, visiones y dinámicas sociales en la ciudad. En, archivo teóricos de Planeamiento I. Cátedra de Planeamiento RKT, Ravella, Olga - Karol, Jorge - Tauber, Fernando. Facultad de Arquitectura y Urbanismo. Universidad. Nacional de La Plata.

Katz, C. (2012). Anatomía del kirchnerismo. O Olho da História, n. 19.

Kullock, D. (1994). Tema III. Aspectos Descriptivos de los Fenómenos Urbanos. En Arquitectura y Ciudad '94. Tomo B. Buenos Aires: FADU-UBA.

Lefebvre, H. (1974). La producción del espacio. Madrid: Capitan Swiny.

López, I. (2013). Territorio y ciudad. Nociones centrales para su comprensión. La Plata: En Apuntes de Cátedra LRE - FAU, UNLP.

López, M. J., Freaza, N., \& al, E. (2014). El sentido de pertenencia y la valoracióndel paisaje frente a los procesos de crecimiento urbano. En C. p. Karol, UPE 11 Conducir las Transformaciones Urbanas: un debate sobre direcciones, orientaciones, estrategias y políticas que modelan la ciudad futura /. La Plata: Universidad Nacional de La Plata.

Losano, G. (2011). Código de ordenamiento urbano y economía urbana. Análisis de una problemática concreta en la ciudad de La Plata. QUID 16, 74-91.

Lynch, K. (1960). La imagen de la ciudad. Barcelona: Editorial GG.

Magnoli, M. (2010). Construir o novo; recriar o existente. Retos urbanísticos y paisajístico de las ciudades brasileñas. Itapema.

Michellod, O. (2001). La identidad del paisaje urbano a través de la memoria. En M. d. Ciudad, Paisaje. Reflaxiones (págs. 247-285). La Plata: Ediciones Al Margen.

Monedero, M. M. (2008). Ciudad y lugar en la reconstrucción de posguerra: del CIAM IV al Regionalismo Crítico. En J. G. Calatrava, Arquitectura y cultura contemporáne (págs. 267-285). Madrid: Abada Editores.

Montañez Gómez, G. (2001). Introdución: Razón y pasión del espacio y el territorio. En G. Montañez Gómez, Espacio y territorios. Roazón, pasión e imaginarios . (págs. 15-32). Bogotá: Unibiblos.

Moya Pillitero, A. M. (2011). La percepción del paisaje urbano. Madrid: Editorial Biblioteca Nueva S. L. 
Murillo, M. (2014). Sistemas de matrices de datos. Archivo del Seminario Introducción a la metodología de la investigación científica Azaretto-Quiroga. La Plata : Maestria de Paisaje FAU-UNLP.

Muxi, Z. (2009). La arquitectura de la ciudad global. Buenos Aires: Nobuko.

Navarro, L., Pasadas, S., \& Ruiz, J. (2004). La triangulación metodológica en el ámbito de la investigación social: dos ejemplos de uso. Recuperado el 06 de 01 de 2017, de http://hdl.handle.net/10261/82068

Nogué, J. (2007). El paisaje como construcción social. Madrid: Biblioteca Nueva.

Nuñez, T. (2010). Paisajes culturales y ordenamiento territorial. Nuevas claves de lectura . En D. Kullok, \& A. (. Novick, Debates sobre ciudad y territorio: los aportes del CIHaM (págs. 195-209). Buenos Aires: Nobuko.

Pacione, M. (1990). Urban problems. An applied urban analysis. . Londres: Routledge.

Ravella, O. (2011). Pasado, presente y futuro de la planificación urbano-regional (Tomo I-II). Buenos Aires: Nobuko.

Roger, A. (2007). Breve tratado del paisaje. Madrid: Editorial Nueva.

Rossi, A. (1982/ 1966). La arquitectura de la ciudad. Barcelona : Editorial GG.

Rubilar Muñoz, L. I. (2015). Valoración de los Paisajes Urbanos del Borde Costero Central. Una estrategia para rescatar su identidad. Caso: Cartagena - Región de Valparaíso Chile. Sevilla: UNIVERSIDAD DE SEVILLA.

Rueda, S. (30 de Junio de 1997). La ciudad compacta y diversa frente a la conurbación difusa. Recuperado el 14 de Novimbre de 2014, de Biblioteca CF+S: http://habitat.aq.upm.es/cs/p2/a009.html

Rueda, S. (2003). Modelos de ordenación del territorio más sostenibles. Boletin $C F+S n^{\circ} 32$, http://habitat.aq.upm.es/boletin/n32/asrue.html\#15.

Sabaté Bell, J. (2005). De la preservación del patrimonio a la ordenación del paisaje. ID Identidades: territorio, cultura, patrimonio, $n^{\circ} 1,15-33$.

Santos, M. (1996). Metamorfosis del espacio habitado. Barcelona: Oikos-Tau.

Seijo, R. (13 de febrero de 2011). La economía kirchnerista. Recuperado el 3 de mayo de 2015, de www.pagina12.com.ar: http://www.pagina12.com.ar/diario/suplementos/cash/434980-2011-02-13.html

SIOC. (s.f.). Recuperado el 11 de 12 de 2015, de http://www.sioc.com.ar/contactenos.php

Soja, E. W. (2004). Seis discursos sobre la postmetroplis. En A. Martín, Lo Urbano (págs. 9198). Barcelona: Ediciones UPC.

Tella, G., \& Silva, R. (2010). La dimensión simbólica del territorio: análisis de caso sobre mecanismos de diferenciación de lugar. Actas del XI Coloquio Internacional de Geocritica. Buenos Aires: Geo Crítica. 
Tella, G., Cañellas, E., Muñoz, M., \& Natale, D. (2011). Importando la torre al barrio. Procesos de densiicación intensiva en la periferia metropolitana de Buenos Aires. Revista Iberoamericana de Estudios Municipales. Año II N³. Primer Semestre, 175 - 199.

Vidal Moranta, T., \& Pol Urrútia, E. (2005). La apropiación del espacio: una propuesta teórica para comprender la vinculación entre las personas y los lugares. Anuario de psicología, vol. 36, $n^{\circ} 3$, págs. 281-297.

Zúñiga Méndez, C. M. (2014). La dimensión simbólica de los espacios urbanos. Un repertorio de apropiaciones espaciales de la zona centro de Tijuana. Bifurcaciones, $\mathrm{n}^{\circ} 18$ ISSN: 0718-1132. 